Report No. BMI-1423

UC-25 Metallurgy and Ceramics (TID-4500, 15th Ed.)

Contract No. W-7405-eng-92

\title{
PROGRESS RELATING TO CIVILIAN APPLICATIONS DURING FEBRUARY, 1960
}

by

Russell W. Dayton

Clyde R. Tipton, Jr.

\author{
March 1, 1960 \\ BATTELLE MEMORIAL INSTITUTE \\ 505 King Avenue \\ Columbus 1 , Ohio
}




\section{DISCLAIMER}

This report was prepared as an account of work sponsored by an agency of the United States Government. Neither the United States Government nor any agency Thereof, nor any of their employees, makes any warranty, express or implied, or assumes any legal liability or responsibility for the accuracy, completeness, or usefulness of any information, apparatus, product, or process disclosed, or represents that its use would not infringe privately owned rights. Reference herein to any specific commercial product, process, or service by trade name, trademark, manufacturer, or otherwise does not necessarily constitute or imply its endorsement, recommendation, or favoring by the United States Government or any agency thereof. The views and opinions of authors expressed herein do not necessarily state or reflect those of the United States Government or any agency thereof. 


\section{DISCLAIMER}

Portions of this document may be illegible in electronic image products. Images are produced from the best available original document. 
REPORTS RELATING TO CIVILIAN APPLICATIONS ISSUEI DURING FEBRUARY, 1960 . $\quad . \quad . \quad . \quad . \quad . \quad . \quad . \quad . \quad 5$

A. REACTOR MATERIALS AND COMPONENTS (AEC-DRD). . . . . . . . . . . . . . . . . . . . . . . . . . 7

Valence Effects of Oxide Additions to Uranium Dioxide . . . . . . . . . . . . . . . . . . . . . . .

High-Pressure High-Temperature Solid-State Stıdies . . . . . . . . . . . . . . . . . . . 10

Irradiation-Surveillance Program on Type 347 Stainless Steel . . . . . . . . . . . . . . . . . 12

Development of Corrosion-Resistant Niobium Alioys . . . . . . . . . . . . . . . . . . . . . . . $\quad . \quad$. 13

Investigation of the Creep Properties of Zircaloy-2 During Irradiation at Elevated Temperatures $\quad . \quad 19$

Determination of Oxygen in Sodium at Concentrations Below 10 PPM . . . . . . . . . . . . 20

Wear and Friction of Sliding Surfaces in Liquid Siodium. . . . . . . . . . . . . . . . . . . . . 21

B. STUDIES OF FUEL ALLOYS (AEC-DRD) . . . . . . . . . . . . . . . . . . . . . . . . . . . . . . . . . 23

Development of Niobium-Uranium Alloys . . . . . . . . . . . . . . . . . . . . . . 23

Development of Thorium-Uranium Alloys . . . . . . . . . . . . . . . . . . . . . 25

C. FISSION-GAS RELEASE FROM REFRACTORY FUELS (AEC-DRD) . . . . . . . . . . . . . . . . . . . . 27

Characterization of Sintered $\mathrm{UO}_{2}$ and Model of Gas Release . . . . . . . . . . . . . . . . . . . 27

Diffusion in $\mathrm{UO}_{2}$.

Preparation for In-Pile Study . . . . . . . . . . . . . . . . . . . . . . . . . 28

D. GENERAL FUEL-ELEMENT DEVELOPMENT (AEC-DRD) . . . . . . . . . . . . . . . . . . . . . 31

Fabrication of Cermet Fuel Elements . . . . . . . . . . . . . . . . . . . . . . 31

Gas-Pressure Bonding of Molybdenum- and Niobium-Clad Fuel Elements . . . . . . . . . . . . . . 32

Factors Affecting Pressure Bonding. . . . . . . . . . . . . . . . . . . . . . . 33

E. GAS-PRESSURE BONDING OF CERAMIC, CERMET, AND DISPERSION FUEL ELEMENTS

(AEC-FUEL CYCLE). . . . . . . . . . . . . . . . . . . . . . . . . . . . . . . 35

F. DEVELOPMENT OF URANIUM CARBIDE (AEC-FUEL CYCLE) . . . . . . . . . . . . . . . . . 39

Alternate Fabrication Methods for UC . . . . . . . . . . . . . . . . . . . . . . . . 39

Melting and Casting Techniques for Uranium-Carbon Alloys . . . . . . . . . . . . . . . . . . . . 40

Metallurgical and Engineering Properties of Uranium Monocarbide. . . . . . . . . . . . . . 41

Uranium Monoca rbide Diffusion Studies . . . . . . . . . . . . . . . . . . . . . . . . . . . . . 41

Irradiation Effects in UC. . . . . . . . . . . . . . . . . . . . . . . . . . . . . . . 43

G. PHYSICAL RESEARCH (AEC-DR)

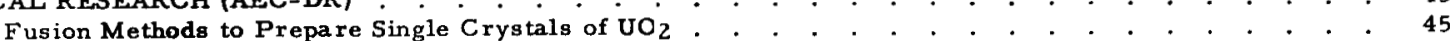

Growth of $\mathrm{UO}_{2}$ Crystals From the Vapor Phase . . . . . . . . . . . . . . . . . . . . 45

H. RADIOISOTOPES AND RADIATION APPLICATIONS (AEC-OD) . . . . . . . . . . . . . . . . . 47

Development of Radioactive-Tracer Quality-Control Systems. . . . . . . . . . . . . . . . . . 47

Use of Intrinsic Radioactive Tracers for Process Control .

Graft-Polymerization Studies . . . . . . . . . . . . . . . . . . . . . . . . . 50

Nitration of Hydrocarbons . . . . . . . . . . . . . . . . . . . . . . . . . . 50

I. VOID-DISTRIBUTION AND HEAT-TRANSFER STUDIES (AEC-EURATOM) . . . . . . . . . . . . . . . 53

J. MATERLALS DEVELOPMENT AND EVALUATION (HAPO) . . . . . . . . . . . . . . . . . . . . . . 55

Mechanical Properties of Zirconium Alloys . . . . . . . . . . . . . . . . . . . . . . . . . 55

Thermal-Neutron-Flux Monitoring System . . . . . . . . . . . . . . . . . . . . . . . . 56

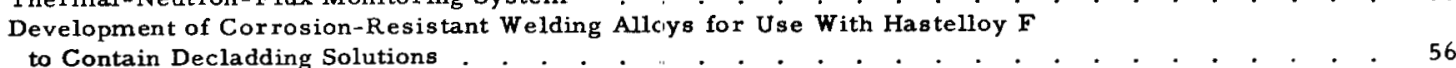

K. DEVELOPMENTS FOR ALUMINUM-CLAD FUEL ELEMENTS (SRL) . . . . . . . . . . . . . . . . . 57

Preparation of Aluminum-Uranium Alloys . . . . . . . . . . . . . . . . . . . . . . . . 57

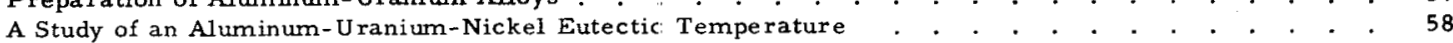

L. EFFECTIVE-INSULATION STUDIES (KAISER) . . . . . . . . . . . . . . . . . . . . . . . . . . 59

M. PROBlems ASSOCiated With THE ReCovery OF SFENT REACtor FUel Elements (ORNL) . . . . 61

Corrosion Studies of the Fluoride-Volatility Process . . . . . . . . . . . . . . . . . . . . . 61

Study of the Effects of Irradiation on Cladding- and Core-Dissolution Processes . . . . . . . . 61 


\section{TABLE OF CONTENTS}

(Continued)

N. VARIABLE-MODERATOR REACTOR CRITICAL-ASSEMBLY STUDIES (ATL-A) . . . . . . . . . . . 63

O. URANIUM CARBIDE AS A REACTOR FUEL (AI) . . . . . . . . . . . . . . . . . . . . . . . . . . . . . . . . 65 Irradiation of Uranium Monocarbide . . . . . . . . . . . . . . . . . . . . . . . . . . . . 65

Postirradiation Examination of Uranium Monocarbide . . . . . . . . . . . . . . . . . . . 65

P. PEBbLE-BED REACTOR MAtERLALS (S \& P) . . . . . . . . . . . . . . . . . . . . . . . . . . . . 69

LABORATORY EVALUATION OF FUELED-GRAPHITE SPHERES $\quad . \quad$. . . . . . . . . . . . . . . . . 69

FABRICA TION DEVELOPMENT OF $\mathrm{Al}_{2} \mathrm{O}_{3}-\mathrm{CLAD}$ UO 2 FUEL PARTIClES . . . . . . . . . . . . . . . 69

Sintered Cladding . . . . . . . . . . . . . . . . . . . . . . . . . . 69

Vapor-Deposited Cladding . . . . . . . . . . . . . . . . . . . . . . . . . . . . . . . 69

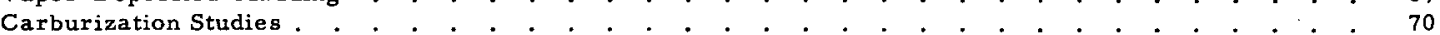

FISSION-PRODUCT RELEASE FROM FUELED-GRAPHITE SPHERES . . . . . . . . . . . . . . . . . 70

Neutron-Activation Studies . . . . . . . . . . . . . . . . . . . . . . . . . . . 70

In-Pile Capsule Experiments . . . . . . . . . . . . . . . . . . . . . . . . . . . . . . . . 72

Q. TANTALUM AND TANTALUM ALLOYS FOR LAMPRE APPLICATIONS (LASL) . . . . . . . . . . . 75

Development of Container Materials for LAMPRE Applications . . . . . . . . . . . . . . . . . . . . . . . 75

Effect of Ir radiation Damage of Tantalum . . . . . . . . . . . . . . . . . . . . . . . . . $\quad .75$

Precipitate Phase Identification and Interstitial-Type Solid Solubility in Tantalum. . . . . . . 76

R. DEVELOPMENTAL STUdIES FOR THE PWR (BAPD) . . . . . . . . . . . . . . . . . . . . . . . . 77

Fabrication of Large-Scale PWR-Type Fuel Plates . . . . . . . . . . . . . . . . . . . 77

S. DEVELOPMENT OF MATERIALS FOR THE MGCR AND HTGR (GA) . . . . . . . . . . . . . . . . . 79

High-Burnup Irradiation Effects in Fuel Materials . . . . . . . . . . . . . . . . . . . . . . . . . 79

Carbon-Transport Corrosion Studies . . . . . . . . . . . . . . . . . . . . . . . . . . . 80

Preparation and Coating of Uranium and Thorium Carbide Powders . . . . . . . . . . . . . . . . . 80

T. DEVELOPMENTAL STUdieS FOR THE SM-2 (ALCO) . . . . . . . . . . . . . . . . . . . . . . . . . . 83

Materials Development . . . . . . . . . . . . . . . . . . . . . . . . . . 83

Encapsulation Studies. . . . . . . . . . . . . . . . . . . . . . . . . . . . . . 87

U. GAS-COOLED REACTOR PROGRAM (AGN) . . . . . . . . . . . . . . . . . . . . . . . 89

MATERLALS DEVELOPMENT PROGRAM . . . . . . . . . . . . . . . . . . . . . . . . . 89

Fabrication of $\mathrm{BeO}-\mathrm{UO}_{2}$ Fuel Pellets . . . . . . . . . . . . . . . . . . . . . . . . . . 89

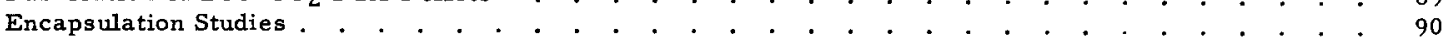

Effects of Irradiation . . . . . . . . . . . . . . . . . . . . . . . . . . . . . 91

GCRE Critical-Assembly Experiments . . . . . . . . . . . . . . . . . . . . . . . . 91

Alloy Modification of Hastelloy X . . . . . . . . . . . . . . . . . . . . . . . . . . . . . . . . . . . . . . .

IN-PILE-LOOP PROGRAM . . . . . . . . . . . . . . . . . . . . . . . . . . . . 92

BRR Loop Program . . . . . . . . . . . . . . . . . . . . . . . . . . . . . . . . . . . . . . . . .92

ETR Loop Program . . . . . . . . . . . . . . . . . . . . . . . . . . . . . . . . . . . . . . 93

V. A STUDY OF THE CORROSION RESISTANCE OF THORIUM AND URANIUM UNDER

ATMOSPHERIC CONDITIONS (UCRL) . . . . . . . . . . . . . . . . . . . . . . . . . . . 95 


\section{5 and 6}

\section{REPORTS RELATING TO CIVILIAN APPLICATIONS}

ISSUED DURING FEBRUARY, 1960

BMI-1374 "Gas-Pressure Bonding of Zircaloy-Clad Flat-Plate Uranium Dioxide Fuel Elements", by Stan J. Paprocki, Edwin S. Hodge, Donald C. Carmichael, and Paul J. Gripshover.

BMI-1397 "Model Studies of Flow and Mixing in the Partially Enriched Gas-Cooled Power Reactor", by Lawrence J. Flanigan, Gale R. Whitacre, and Herbert R. Hazard.

BMI-1405 "Behavior of Rubbing Molybdenum Surfaces in Sodium Environments", by John W. Kissel, Carl W. Melton, and William A. Glaeser.

BMI- 1406 "Radiation Effects on Boron-Cortaining Compounds", by Donald J. Hamman and Paul Schall.

BMI- 1408 "A Method of Correlating Irradiation Effects in Dispersion Fuels", by Donald L. Keller, Lewis E. Hulbert, and Bruce W. Dunnington.

BMI- 1409 "Progress Relating to Civilian A.pplications During January, 1960", by Russell W. Dayton and Clyde R. Tipton, Jr. 
<smiles>c1ccccc1</smiles>

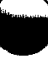




\title{
$\mathrm{A}-\mathrm{l}$. \\ REACTOR MATERIALS AND COMPONENTS (AEC-DRD)
}

\author{
R. F. Dickerson
}

Structural studies of $\mathrm{U}_{3} \mathrm{O}_{8}-\mathrm{La}_{2} \mathrm{O}_{3}$ solid solutions indicate that the fluorite solid solution is formed and that the lattice parameters are in general agreement with those previously obtained by an oxidation of $\mathrm{UO}_{2}-\mathrm{L}_{2} \mathrm{O}_{3}$ solid solutions of corresponding $\mathrm{La}_{2} \mathrm{O}_{3}$ content. Preliminary results from electrical studies indicate that the "valencecompensated", air-fired $\mathrm{U}_{3} \mathrm{O}_{8}-\mathrm{La}_{2} \mathrm{O}_{3}$ solid solutions containing greater than equimolar amounts of $\mathrm{La}_{2} \mathrm{O}_{3}$ are poor conductors. A direct determination of the vapor pressure of uranium oxide is being undertaken for a series of $\mathrm{UO}_{2}-\mathrm{La}_{2} \mathrm{O}_{3}$ solid solutions.

Precise determinations of the oxygen content of the uranium oxides subjected to pressure has been undertaken. These analyses show that the gamma high-pressure modification of $\mathrm{U}_{3} \mathrm{O}_{8}$ has an oxygen-to-uranium ratio essentially the same as the starting $\mathrm{U}_{3} \mathrm{O}_{8}$. In addition, reduction to lower oxides does not occur at $1300 \mathrm{C}$ with applied pressures of 100,000 atm. A study of reactions under pressure of $\mathrm{UO}_{2}$ containing $\mathrm{Al}_{2} \mathrm{O}_{3}$ and/or $\mathrm{MgO}$ was initiated. No reaction between $\mathrm{UO}_{2}$ and $\mathrm{Al}_{2} \mathrm{O}_{3}$ has been detected. A sample of $\mathrm{UO}_{2}$ containing 50 mole per cent $\mathrm{MgO}$ reacted to form a solid solution of fluorite structure. Since it is not certain whether this solubility was the result of excess oxygen in the $\mathrm{UO}_{2}$ or of the pressure applied further study is in progress.

The irradiation of 11 capsules containing specimens of Type 347 stainless steel is being continued in the ETR. In addition, two capsules designed to operate at temperatures of about $600 \mathrm{~F}$ (gamma heating) have been inserted in the WTR. Temperature measurements of the specimens obtained during runs at 20, 25, and 30 megawatts indicate that the design temperature $(600 \mathrm{~F})$ will be reached when the reactor operates at 60 megawatts.

The study of high-strength niobium-basse alloys for possible EBR cladding applications has been temporarily discontinued and is not reported herein. However, corrosion testing of alloys being studied for water corrosion resistance has continued. In geveral, alloys containing more than $45 \mathrm{a} / 0$ zirconium and a ternary containing 28 a/o titanium6 a/o chromium appear most corrosion resistant. A binary alloy of niobium and 12.6 a/o vanadium possesses the optimum combination of high-temperature strength, low thermal-neutron cross section, and adeauate corrosion resistance.

The fabrication of components for capsules designed for in-pile creep testing of zirconium has been initiated, and arrangements are being made for ir radiations in the WTR. The decrease of internal friction in Zircaloy wire with time after straining 0.5 per cent was determined. The change noted is typical of that associated with the Köster effect and probably does not indicate strain aging. Additional tensile tests performed on Zircaloy- 2 at various temperatures show the presence of a yield point after initial plastic strain which indicates a phenomenon similar to strain aging.

The studies concerned with the development of techniques for the determination of oxygen concentrations in sodium below $10 \mathrm{ppm}$ have been continued. The various equipment developments and modifications needed for the various techniques are complete, and actual tests will be initiated in the near future. In previous studies of the wear and 


\section{A-2}

friction of sliding surfaces in liquid sodium, ball and flat specimens, with and without sodium lubrication, were investigated. It was found that $\mathrm{MoO}_{2}$ and $\mathrm{Na}_{2} \mathrm{MoO}_{4}$ on the surfaces reduced friction and wear. Attempts are being made to deposit coatings of molybdenum-containing compounds on metals such as stainless steel.

Valence Effects of Oxide Additions to Uranium Dioxide

W. B. Wilson and C. M. Schwartz

An investigation is being conducted on the stabilizing influence of oxide additions to uranium oxide. Previous work has been directed toward determination of the mechanism of stabilization of rare-earth oxide additions to uranium oxide exposed to an oxidizing atmosphere at elevated temperatures. Current work has been devoted to fabrication and evaluation of solid solutions of $\mathrm{U}_{3} \mathrm{O}_{8}$ containing 40,50, and 60 mole per cent $\mathrm{La}_{2} \mathrm{O}_{3}$. An additional sample of $\mathrm{U}_{3} \mathrm{O}_{8}$ containing 25 mole per cent $\mathrm{Y}_{2} \mathrm{O}_{3}$ and 25 mole per cent $\mathrm{MgO}$ was also fabricated in an attempt to lower both the amount and nuclear cross section of the additive. These compositions were sintered at $1760 \mathrm{C}$ in air for periods of 1 , 5 , and $20 \mathrm{hr}$, which is identical to the air oxidation used previously to evaluate the stability of the solid solutions of $\mathrm{UO}_{2}$ containing additions.

The weight losses of the above solid solutions, previously reported, were generally greater than those obtained by air oxidation of samples in which the uranium was incorporated as $\mathrm{UO}_{2}$. It is believed that these weight losses are the result of diffusion into the $\mathrm{BeO}$ setter on which the sample was heated, since the $\mathrm{BeO}$ was discolored following the air-oxidation treatment. Further weight-change experiments will be performed to minimize diffusion of the sample and permit a more accurate evaluation of the weight losses to be expected of these materials.

Structural studies of the $\mathrm{U}_{3} \mathrm{O}_{8}-\mathrm{La}_{2} \mathrm{O}_{3}$ solid solutions indicate that they form the fluorite solid solution as previously reported by Hund. The lattice parameters, however, are considerably larger than those reported by Hund and are in general agreement with those previously obtained by air oxidation of $\mathrm{UO}_{2}-\mathrm{La}_{2} \mathrm{O}_{3}$ solid solutions of corresponding $\mathrm{La}_{2} \mathrm{O}_{3}$ content. Table A-l gives the lattice parameters of the above solid solutions, as initially sintered at $1200 \mathrm{C}$ and $1375 \mathrm{C}$ each for $24 \mathrm{hr}$ followed by additional air oxidation at $1760 \mathrm{C}$ for 1,5 , and $20 \mathrm{hr}$. These parameters may be compared to the $\mathrm{UO}_{2}-\mathrm{La}_{2} \mathrm{O}_{3}$ solid solutions and to Hund's $\mathrm{U}_{3} \mathrm{O}_{8}-\mathrm{La}_{2} \mathrm{O}_{3}$ by reference to BMI- 1328.

In contrast to the behavior of the $\mathrm{UO}_{2}-\mathrm{La}_{2} \mathrm{O}_{3}$ solid solutions, the present $\mathrm{U}_{3} \mathrm{O}_{8}-$ $\mathrm{La}_{2} \mathrm{O}_{3}$ parameters given in Table A-1 show very little or no change with extensive firing at high temperature. The decrease in lattice parameter upon oxidation of the $\mathrm{UO}_{2}-\mathrm{La}_{2} \mathrm{O}_{3}$ solid solutions is as sociated with the oxidation of these materials.

Chemical analyses and electrical studies of these solid solutions are not, as yet, complete. A preliminary evaluation of the electrical characteristics of the $\mathrm{U}_{3} \mathrm{O}_{8}-\mathrm{La}_{2} \mathrm{O}_{3}$ solid solutions indicates that the 40 mole per cent $\mathrm{La}_{2} \mathrm{O}_{3}$ was p-type while the 50 and 60 mole per cent $\mathrm{La}_{2} \mathrm{O}_{3}$ were $\mathrm{n}$-type. The same change in sign of the thermoelectric power was observed for the $\mathrm{UO}_{2}-\mathrm{La}_{2} \mathrm{O}_{3}$ solid solutions previously reported. The roomtemperature resistivities of the $\mathrm{U}_{3} \mathrm{O}_{8}-40$ mole per cent $\mathrm{La}_{2} \mathrm{O}_{3}$ appear to be of the order 
A-3

TABLE A-1. LATTICE PARAMETERS OF SOLID SOLUTIONS AFTER AIR OXIDATION AT $1760 \mathrm{C}$

\begin{tabular}{|c|c|c|c|c|c|}
\hline \multirow[b]{2}{*}{ Sample } & \multirow[b]{2}{*}{$\begin{array}{l}\text { Intended Composition, } \\
\text { mole per cent }\end{array}$} & \multicolumn{4}{|c|}{$\begin{array}{c}\text { Lattice Parameter After Indicated Sintering Temperature } \\
\text { and Time, A }\end{array}$} \\
\hline & & $\begin{array}{l}1375 \mathrm{C} \\
24 \mathrm{Hr}\end{array}$ & $\begin{array}{l}1760 \mathrm{C} \\
1 \mathrm{Hr}\end{array}$ & $\begin{array}{l}1760 \mathrm{C} \\
5 \mathrm{Hr}\end{array}$ & $\begin{array}{l}1760 \mathrm{C}, \\
20 \mathrm{Hr}\end{array}$ \\
\hline 176 & $\mathrm{U}_{3} \mathrm{O}_{8}-40 \mathrm{La}_{2} \mathrm{O}_{3}$ & 5.52 & 5.52 & 5.53 & 5.55 \\
\hline 174 & $\mathrm{U}_{3} \mathrm{O}_{8}-50 \quad \mathrm{La}_{2} \mathrm{O}_{3}$ & 5.56 & 5.55 & 5.55 & 5.54 \\
\hline 175 & $\mathrm{U}_{3} \mathrm{O}_{8}-60 \mathrm{La}_{2} \mathrm{O}_{3}$ & $5.55^{(a)}$ & 5.58 & 5.58 & 5.58 \\
\hline 177 & $\mathrm{U}_{3} \mathrm{O}_{8}-25 \mathrm{Y}_{2} \mathrm{O}_{3}-25 \mathrm{MgO}$ & 5.34 & 5.32 & 5.32 & 5.32 \\
\hline
\end{tabular}

(a) The low parameter was due to incomplete solid solution of the $\mathrm{La}_{2} \mathrm{O}_{3}$ at the lower $1375 \mathrm{C}$ sintering temperature. The $1760 \mathrm{C}$ firing was performed to homogenize the samples and evaluate their weight-loss characteristics. 
of $10^{2} \mathrm{ohm}-\mathrm{cm}$, the $\mathrm{U}_{3} \mathrm{O}_{8}-50$ mole per cent $\mathrm{La}_{2} \mathrm{O}_{3}$ near $10^{4} \mathrm{ohm}-\mathrm{cm}$, and the $\mathrm{U}_{3} \mathrm{O}_{8}-60$ mole per cent $\mathrm{La}_{2} \mathrm{O}_{3}$ greater than $10^{6} \mathrm{ohm-cm}$. Thus, the "valence-compensated" airfired $\mathrm{U}_{3} \mathrm{O}_{8}-\mathrm{La}_{2} \mathrm{O}_{3}$ solid solutions containing greater than equimolar amounts of $\mathrm{La}_{2} \mathrm{O}_{3}$ are poor conductors.

In previous experimental work the stability of the $\mathrm{UO}_{2}-\mathrm{La}_{2} \mathrm{O}_{3}$ solid solutions has been evaluated by firing compacts in air at temperatures to $1760 \mathrm{C}$ and evaluating weight change. In such experiments the loss of uranium oxide by volatility or "transpiration" is qualitatively related to the weight change. A direct determination of the vapor pressure of uranium oxide is being undertaken for a series of solid solutions ranging from $\mathrm{UO}_{2}$ to $\mathrm{UO}_{2}$ containing 54 mole per cent $\mathrm{La}_{2} \mathrm{O}_{3}$. The results will define the variation of the vapor pressure as a function of the $\mathrm{La}_{2} \mathrm{O}_{3}$ additive.

\section{High-Pressure High-Temperature Solid-State Studies}

W. B. Wilson and C. M. Schwartz

An investigation is being conducted on the effects of combined ultrahigh pressure and high temperature on the uranium-oxygen system and on the reaction of the uranium oxides with various mixed oxides. A more precise determination of the oxygen content of the uranium oxides subjected to pressure has been undertaken using microbalance techniques. The new results were obtained by reduction of the oxides to $\mathrm{UO}_{2}$ in dry hydrogen at $900 \mathrm{C}$, followed by reoxidation to stoichiometric $\mathrm{U}_{3} \mathrm{O}_{8}$ in dry air at $750 \mathrm{C}$.

The results have shown that the original starting $\mathrm{U}_{3} \mathrm{O}_{8}$, previously assumed to be $\mathrm{UO}_{2.67}$, had gained a small amount of oxygen upon standing in air. This excess oxygen, possibly chemisorbed on the surface of the $\mathrm{U}_{3} \mathrm{O}_{8}$ powder, is incorporated into the structure of the high-pressure phases upon application of high pressure and temperature. The results of the analysis are given in Table $\mathrm{A}-2$.

The results of Table A-2 show that the gamma high-pressure modification of $\mathrm{U}_{3} \mathrm{O}_{8}$ has an oxygen-to-uranium ratio of $\mathrm{UO}_{2}$. 72 , which is essentially the same as that of the starting $\mathrm{U}_{3} \mathrm{O}_{8}$ material. The slight difference given in Table $\mathrm{A}-2$ between the gamma $\mathrm{U}_{3} \mathrm{O}_{8}$ and the starting material is attributed to the los $\mathrm{s}$ of the chemisorbed oxygen during heating in the microbalance apparatus. In the high-pressure apparatus, this chemisorbed oxygen is incorporated into the structure of the oxide, producing slightly higher oxygen-to-uranium ratios.

The results of Table A-2 also show that reduction to the lower oxides of uranium has not occurred even at $1300 \mathrm{C}$ at the higher pressure. Previous results at 50,000 atm at these temperatures showed a distinct oxygen loss upon heating to comparable temperatures.

A determination of the density and the oxygen-to-uranium ratio of the $\mathrm{U}_{4} \mathrm{O}_{9}$ material used in the present high-pressure work was undertaken. Table A-2 shows that the oxygen-to-uranium ratio corresponds to $\mathrm{UO}_{2} .26$. A density determination of this material, using the helium-compression method, gave a value of $10.43 \pm 0.18 \mathrm{~g}$ per $\mathrm{cm}^{3}$. A previous determination, using the vacuum-pycnometric method, yielded a value of 
$A-5$

TABLE A-2. MICROBALANCE ANALYSES OF THE OX YGEN-TO-URANIUM RATIO FOR URANIUM OXIDES SUB JECTED TO PRESSURE AND TEMPERATURE

\begin{tabular}{|c|c|c|c|c|}
\hline Sample & Phases & $\begin{array}{c}\text { Pressure, } \\
\text { atm }\end{array}$ & $\begin{array}{c}\text { Temperature, } \\
\text { C }\end{array}$ & Oxygen-to-Uranium Ratio \\
\hline 1 & Initial $\mathrm{U}_{3} \mathrm{O}_{8}$ & 0 & 0 & 2.70 \\
\hline 163 & Gamma plus cubic(a) & 100,000 & 500 & 2.72 \\
\hline 164 & Gamma (b) & 100,000 & 700 & 2.73 \\
\hline 165 & Complex $(\mathrm{c})$ & 100,000 & 900 & 2.69 \\
\hline 166 & Complex & 100,000 & 1100 & 2.66 \\
\hline 167 & Complex & 100,000 & 1300 & 2.68 \\
\hline $146 \mathrm{~A}$ & Initial $\mathrm{U}_{4} \mathrm{O}_{9}$ & 0 & 0 & 2.26 \\
\hline
\end{tabular}

(a) The description "cubic" here refers to the $\mathrm{U}_{4} \mathrm{O}_{9}$ cubic fluorite structure which is believed to contain considerable excess oxygen (i. e., cubic $\mathrm{U}_{3} \mathrm{O}_{8}$ ).

(b) Gamma here refers to the high-pressure form of $\mathrm{U}_{3} \mathrm{O}_{8}$.

(c) The term "complex" is used to describe a structure which bears marked analogy to $\mathrm{U}_{4} \mathrm{O}_{9}$ but has lower (than cubic) symmetry. 
$10.33 \mathrm{~g}$ per $\mathrm{cm}^{3}$. The theoretical density of $\mathrm{U}_{4} \mathrm{O}_{9}$, based upon an oxygen interstitial model, requires a density of $11.31 \mathrm{~g}$ per $\mathrm{cm}^{3}$, while that based upon a uranium vacancy model requires a density of $10.26 \mathrm{~g}$ per $\mathrm{cm}^{3}$. It may be seen that the present results are in better agreement with the latter alternative. A redetermination of the helium density of the initial $\mathrm{U}_{4} \mathrm{O}_{9}$ is under way, using a larger sample, in order to obtain more precise results for correlation with the high-pressure studies of the uranium oxides.

The $\mathrm{U}_{4} \mathrm{O}_{9}$ material described above was subjected to pressures of 75,000 atm and examined by X-ray diffraction. No change or reduction to $\mathrm{UO}_{2}$ was observed as previously experienced, indicating that the earlier sample had probably been reduced because of a crack in the heater tube in which it was contained.

The study of reactions under pressure of $\mathrm{UO}_{2}$ containing $\mathrm{Al}_{2} \mathrm{O}_{3}$ and/or $\mathrm{MgO}$ was initiated. No reaction was detected between $\mathrm{UO}_{2}$ and $\mathrm{Al}_{2} \mathrm{O}_{3}$. The $\mathrm{UO}_{2}-50$ mole per cent $\mathrm{MgO}$ sample reacted to form a solid solution of fluorite structure with a lattice parameter of $5.32 \mathrm{~A}$. Excess $\mathrm{MgO}$ was present, indicating that complete solid solution was not obtained. It is known that excess oxygen in $\mathrm{UO}_{2}$ increases the solubility of $\mathrm{MgO}$ in the $\mathrm{UO}_{2}$ structure. Thus, it must be determined whether the solid solution formed with $\mathrm{MgO}$ was the result of pressure or because the sample was sufficiently oxidized to increase the $\mathrm{MgO}$ solid solubility. The same general reaction has been previously reported for $\mathrm{UO}_{2}-\mathrm{Sc}_{2} \mathrm{O}_{3}$.

Additional calibration work was undertaken on the high-pressure apparatus to evaluate its use as a "compressible-gasket" device. The results indicated that additional sample height may be obtained through use of this technique.

Work will continue on the study of reactions of the uranium oxides with other refractory oxides.

Irradiation-Surveillance Program on Type 347 Stainless Steel

W. E. Murr, F. R. Shober, R. L. Ritzman, and J. F. Lagedrost

The stainless steel surveillance program has as its objective the determination of mechanical-property changes occurring in AISI Type 347 stainless steel when irradiated to total fast-neutron exposures of about 0.5 to $1.5 \times 10^{22} \mathrm{nvt}$. Information gained from capsule-irradiated subsize tensile, cyclic-strain fatigue, and impact specimens will be used to determine the type and degree of damage occurring in the operating KAPL loop and in other loops and structural members of this material operating in fast-neutron flux fields.

At the present time, 11 capsules are being irradiated in the ETR. Three capsules have been in-pile since August, 1959, and eight have been in-pile since June, 1958. The group of three will be given postirradiation anneals prior to mechanical testing, while the group of eight will be tested at room temperature. The total estimated exposures for all capsules as of January 11,1960 (end of Cycle 25), was given previously in 
BMI-1409. ETR Cycle 26 was initiated on January 22 and ended on February 15 for an estimated total of about 3000-megawatt days; however, specific power-generation data are not available at this time.

The first two capsules designed to operate at temperatures of about $600 \mathrm{~F}$ by gamma heating of specimens and capsule cornponents were inserted in Position $L-7$ of the Westinghouse Test Reactor on February 18. Temperature measurements obtained by thermocouples located adjacent to specimens during runs at 20, 25, and 30 megawatts indicated that the design temperature of about $600 \mathrm{~F}$ will be reached at 60 -megawatt operation. The reactor is in the process of escalation to a 60-megawatt power level, which it should reach sometime in April. At that time, a third capsule will be inserted in the reactor.

\section{Development of Corrosion-Resistant Niobium Alloys}

D. J. Maykuth, W. D. Klopp, R. I. Jaffee, W. E. Berry, and F. W. Fink

The mechanical-property evaluation of selected niobium alloys for possible service in pressurized-water reactors was concluded. Previous work had shown that optimum properties were obtained in a binary 12.6 a/o vanadium alloy. In the recent work, alloys of lower total alloy content were evaluated with the intent of improving fabricability and reducing the thermal-neutron-absorption cross section while still maintaining good corrosion resistance and hot strength.

Corrosion testing of alloys in 600 and $680 \mathrm{~F}$ water and $750 \mathrm{~F} 1500$-psi steam has been continued. The results obtained to date for exposure times ranging up to 308 days are summarized in Table A-3. In general, alloys containing more than $45 \mathrm{a} / 0$ zirconium and a ternary containing 28 a/o titanium- 6 a/o chromium appear most corrosion resistant. They possess adherent tarnish films and low weight gains. An exception is the binary 65 a/o zirconium alloy, which began to exhibit edge cracking after 168 days of exposure to $680 \mathrm{~F}$ water. A 12.6 a/o vanadium alloy possesses the optimum combination of high-temperature strength, low cross section, and adequate corrosion resistance.

Vanadium-zirconium and vanadium-titanium alloys containing additions of carbon and oxygen for increased strength have now been exposed 28 days to $680 \mathrm{~F}$ water. Weight gains for these alloys also-are included in Table A-3. They are low and compare favorably with those for similar alloys which contain lower amounts of these interstitials. The results confirm earlier observations that alloys prepared from commercial-purity niobium (high in interstitials) were as corrosion resistant as those prepared from highpurity niobium (low in interstitials).

Elevated-temperature tensile tests were conducted on a series of binary and ternary niobium-base alloys containing 5 to $8.7 \mathrm{a} / 0$ vanadium. These data are summarized in Table A-4 along with similar data for the 12.6 a/o vanadium alloy for purposes of comparison. These results show that, while alloy strength decreases with total alloy content, good strengths a re obtained at levels down through 5 a/o vanadium. The intentional addition of interstitial impurity elements to alloys containing 5 to 8.7 a/o vanadium 
A-8

TABLE A-3. SUMMARY OF CORROSION RESULTS OBTAINED ON NIOBIUM ALLOYS EXPOSED TO HIGH-TEMPERATURE WATER AND STEAM

\begin{tabular}{|c|c|c|c|c|c|c|}
\hline \multirow[b]{2}{*}{$\begin{array}{c}\text { Alloy Addition } \\
\text { (Balance Niobium), } \\
\text { a/o }\end{array}$} & \multicolumn{2}{|c|}{$600 \mathrm{~F}$ Water } & \multicolumn{2}{|c|}{$680 \mathrm{~F}$ Water } & \multicolumn{2}{|c|}{$750 \mathrm{~F}$ Steam } \\
\hline & $\begin{array}{c}\text { Exposure } \\
\text { Time, } \\
\text { days }\end{array}$ & $\begin{array}{l}\text { Total Weight } \\
\text { Change, } \\
\text { mg per } \mathrm{cm}^{2}\end{array}$ & $\begin{array}{l}\text { Exposure } \\
\text { Time, } \\
\text { days }\end{array}$ & $\begin{array}{l}\text { Total Weight } \\
\text { Change, } \\
\text { mg per } \mathrm{cm}^{2}\end{array}$ & $\begin{array}{l}\text { Exposure } \\
\text { Time, } \\
\text { days }\end{array}$ & $\begin{array}{c}\text { Total Weight } \\
\text { Change, } \\
\text { mg per } \mathrm{cm}^{2}\end{array}$ \\
\hline \multicolumn{7}{|c|}{ Commercial Niobium, Rocking-Hearth Melts } \\
\hline Unalloyed $\mathrm{Nb}$ & 308 & -50.5 & $42^{(a)}$ & Disintegrated & $28(\mathrm{a})$ & Disintegrated \\
\hline $10.5 \mathrm{Zr}$ & -- & -- & $196^{(a)}$ & 0.67 & 210 & -39.7 \\
\hline $26.1 \mathrm{Zr}$ & -- & -- & $196^{(a)}$ & 0.07 & -- & -- \\
\hline $35.7 \mathrm{Zr}$ & -- & - & 196 (a) & 0.66 & -- & $\cdots$ \\
\hline $45.7 \mathrm{Zr}$ & -- & -- & $196(a)$ & 0.55 & -- & -- \\
\hline $1.08 \mathrm{~W}$ & -- & -- & $196(\mathrm{a})$ & -2.60 & 210 & -64.2 \\
\hline $4.67 \mathrm{~W}$ & -- & -- & $196(a)$ & -29.3 & -- & -- \\
\hline $9.56 \mathrm{~W}$ & -- & -- & $196(a)$ & Cracked & -- & -- \\
\hline $2.45 \mathrm{Mo}$ & -- & -- & 196 (a) & -7.10 & 98 & Disintegrated \\
\hline $5.20 \mathrm{Mo}$ & -- & -- & $196^{(a)}$ & -1.30 & 210 & -184.5 \\
\hline $7.40 \mathrm{Mo}$ & - & -- & $196^{(a)}$ & 0.62 & -- & -- \\
\hline $4.42 \mathrm{~V}$ & -- & -- & $196^{(a)}$ & 0.42 & 210 & -24.0 \\
\hline $6.59 \mathrm{~V}$ & -- & -- & $196^{(a)}$ & 0.73 & 210 & 1.28 \\
\hline $8.93 \mathrm{~V}$ & -- & -- & $196^{(a)}$ & 0.59 & 210 & 1.18 \\
\hline $10.7 \mathrm{~V}$ & -- & -- & $196^{(a)}$ & 0.78 & $\therefore$ & -- \\
\hline $13.7 \mathrm{~V}$ & -- & - & $196^{(a)}$ & 0.50 & -- & -- \\
\hline $24.2 \mathrm{~V}$ & -- & -- & $196^{(a)}$ & 0 & -- & -- \\
\hline $4.90 \mathrm{Fe}$ & -- & -- & $196(a)$ & 0.10 & 98 & Disintegrated \\
\hline $9.41 \mathrm{Ti}$ & -- & -- & 196 (a) & 0.65 & 182 & 1.19 \\
\hline $18.8 \mathrm{Ti}$ & -- & -- & $196(\mathrm{a})$ & 0.48 & -- & $\therefore$ \\
\hline $24.3 \mathrm{Ti}$ & -- & -- & $196^{(a)}$ & 0.52 & -- & -- \\
\hline $30.5 \mathrm{Ti}$ & -- & -- & $196(\mathrm{a})$ & 0.40 & -- & -- \\
\hline $33.8 \mathrm{Ti}$ & -- & -- & $196^{(a)}$ & 0.33 & -- & - \\
\hline $12.0 \mathrm{Ti}-0.5 \mathrm{Cr}$ & -- & - & $196(a)$ & 0.66 & -- & -- \\
\hline $20.2 \mathrm{Ti}-2.1 \mathrm{Cr}$ & -- & -- & 196 (a) & 0.39 & -- & -- \\
\hline $28.2 \mathrm{Ti}-6.1 \mathrm{Cr}$ & -- & -- & $196^{(a)}$ & 0.20 & -- & -- \\
\hline $12.0 \mathrm{Ti}-4.2 \mathrm{Mo}$ & -- & -- & $196^{(a)}$ & 0.64 & -- & -- \\
\hline $17.4 \mathrm{Ti}-6.2 \mathrm{Mo}$ & $-\infty$ & -. & $196^{(a)}$ & 0.54 & -- & -- \\
\hline $23.1 \mathrm{Ti}-7.8 \mathrm{Mo}$ & -- & -- & $196^{(a)}$ & 0.45 & -- & -- \\
\hline $10.4 \mathrm{~T} \mathbf{i}-5.0 \mathrm{~V}$ & -- & -. & $196^{(\mathrm{a})}$ & 0.56 & -- & -- \\
\hline $16.1 \mathrm{Ti}-8.4 \mathrm{~V}$ & -- & -- & 196 (a) & 0.40 & -- & -- \\
\hline $22.6 \mathrm{Ti}-11.0 \mathrm{~V}$ & -- & -- & $196^{(a)}$ & 0.48 & -- & -- \\
\hline \multicolumn{7}{|c|}{ High-Purity Niobium, Consumable-Electrode Melts } \\
\hline Unalloyed $\mathrm{Nb}$ & 308 & 0.70 & 308 & -7.22 & $224^{(a)}$ & -54.0 \\
\hline $7.18 \mathrm{Mo}$ & 308 & 0.64 & 252 (a) & Cracked & $70(a)$ & Cracked \\
\hline
\end{tabular}


A-?

TABLE A-3. (Continued)

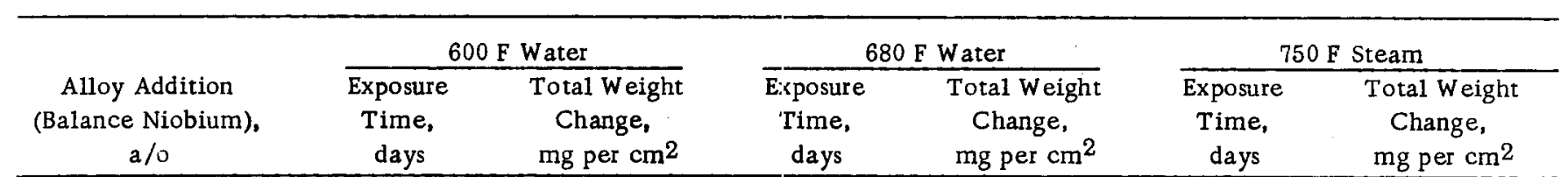

High-Purity Niobium, Consumatle-Electrode Melts (Continued)

\begin{tabular}{|c|c|c|c|c|c|c|}
\hline $12.6 \mathrm{~V}$ & 308 & 0.35 & 308 & 0.72 & 296 & 0.76 \\
\hline $46.8 \mathrm{Zr}-5.06 \mathrm{Ti}$ & 280 & 0.25 & 280 & 1.03 & 266 & 2.51 \\
\hline $11.2 \mathrm{Ti}-3.2 \mathrm{Mo}$ & 280 & 0.22 & 280 & 0.66 & 266 & $0.36^{(b)}$ \\
\hline $18.8 \mathrm{Ti}-8.7 \mathrm{Mo}$ & 280 & 0.36 & 280 & 0.66 & 266 & 0.53 \\
\hline $9.9 \mathrm{Zr}-9.4 \mathrm{~V}$ & 196 & $0.14(\mathrm{~b})$ & 196 & $0.23(\mathrm{~b})$ & 182 & -5.87 \\
\hline $5.7 \mathrm{Zr}-11.4 \mathrm{~V}$ & 196 & $0.07^{(b)}$ & 196 & 0.43 & 182 & -2.15 \\
\hline $9.1 \mathrm{Ti}-6.3 \mathrm{Cr}$ & 196 & $0.08^{(b)}$ & 196 & 0.51 & 182 & -4.99 \\
\hline $7.5 \mathrm{~V}$ & 28 & 0.24 & 28 & 0.23 & 28 & 0.99 \\
\hline $7.5 \mathrm{~V}-0.19 \mathrm{~N}$ & 28 & 0.18 & 28 & 0.28 & 28 & 0.51 \\
\hline $7.5 \mathrm{~V}-2.5 \mathrm{Ti}$ & 28 & 0.21 & 28 & 0.34 & 28 & 0.48 \\
\hline $7.5 \mathrm{~V}-2.5 \mathrm{Mo}$ & 28 & 0.27 & 28 & 0.28 & 28 & 0.66 \\
\hline
\end{tabular}

High-Purity Niobium, Rocking-Hearth Melts

Unalloyed $\mathrm{Nb}$

Unalloyed $\mathrm{Nb}$

Unalloyed $\mathrm{Nb}$

$1.1 \mathrm{Zr}$

$2.2 \mathrm{ZI}$

$5 \mathrm{Zr}$

$10.2 \mathrm{Zr}$

$40 \mathrm{Zr}$

$65 \mathrm{Zr}$

$75 \mathrm{Zr}$

$90 \mathrm{Zr}$

$3.2 \mathrm{Ti}$

$10.5 \mathrm{Ti}$

$25.0 \mathrm{Ti}$

$<0.02 \mathrm{Cr}$

$0.5 \mathrm{Cr}$

$0.5 \mathrm{Cr}$

$<0.08 \mathrm{Fe}$

$0.3 \mathrm{Fe}$

$10 \mathrm{Fe}$
$-$

$--$

$-$

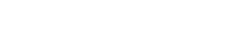

$--$

--

-

-

$--\quad \quad-$

$\begin{array}{lll}-- & -- & 196\end{array}$

$\begin{array}{lll}-- & - & 196\end{array}$

$\begin{array}{lll}-- & -- & 224\end{array}$

$\begin{array}{lll}- & - & \\ - & - & 224\end{array}$

$\begin{array}{lll}-- & -- & 224\end{array}$

$\begin{array}{lll}- & - & 224\end{array}$

$\begin{array}{lll}-- & -- & 224\end{array}$

$\begin{array}{lll}-- & -- & 196\end{array}$

--

-

--

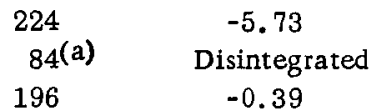

$168^{(a)} \quad$ Disintegrated

$112 \quad-17.8$

$196 \quad-14.5$

$196-0.03$

$196 \quad 0.78$

$196-1.12$, edge

cracking

1. 28

1.42

$-10.3$

0.76

0.48

$-3.87$

$-1.35$

$-4.95$

$196-1.82$

112

$28^{(a)}$
$-11.8$

Cracked

$\begin{array}{ll}-- & -- \\ -- & -- \\ -- & --\end{array}$

--

$\begin{array}{lll}-- & - \\ -- & -\end{array}$

$--$

--

-

--

-.

--

$-$

$-$

-- $\quad-$ 


$$
A-10
$$

TABLE A-3. (Continued)

\begin{tabular}{|c|c|c|c|c|c|c|}
\hline \multirow[b]{2}{*}{$\begin{array}{c}\text { Alloy Addition } \\
\text { (Balance Niobium), } \\
\mathrm{a} / \mathrm{0} \\
\end{array}$} & \multicolumn{2}{|c|}{$600 \mathrm{~F}$ Water } & \multicolumn{2}{|c|}{$680 \mathrm{~F}$ Water } & \multicolumn{2}{|c|}{$750 \mathrm{~F}$ Steam } \\
\hline & $\begin{array}{c}\text { Exposure } \\
\text { Time, } \\
\text { days }\end{array}$ & $\begin{array}{l}\text { Total Weight } \\
\text { Change, } \\
\text { mg per } \mathrm{cm}^{2}\end{array}$ & $\begin{array}{l}\text { Exposure } \\
\text { Time, } \\
\text { days }\end{array}$ & $\begin{array}{l}\text { Total Weight } \\
\text { Change, } \\
\text { mg per } \mathrm{cm}^{2}\end{array}$ & $\begin{array}{c}\text { Exposure } \\
\text { Time, } \\
\text { days }\end{array}$ & $\begin{array}{l}\text { Total Weight } \\
\text { Change, } \\
\text { mg per } \mathrm{cm}^{2}\end{array}$ \\
\hline \multicolumn{7}{|c|}{ High-Purity Niobium, Rocking-Hearth Melts (Continued) } \\
\hline $10.9 \mathrm{Zr}-5.1 \mathrm{Ti}$ & -- & -- & 196 & 0.60 & -- & -- \\
\hline $25 \mathrm{Zr}-5 \mathrm{Ti}$ & -- & -- & 196 & -0.22 & -- & -- \\
\hline $25 \mathrm{Zr}-15 \mathrm{Ti}$ & -- & -- & 196 & 0.47 & -- & - \\
\hline $25 \mathrm{Zr}-25 \mathrm{Ti}$ & -- & -- & 196 & 0.47 & -- & -- \\
\hline $35 \mathrm{Zr}-5 \mathrm{Ti}$ & $-\infty$ & -- & 196 & 0.71 & -- & -- \\
\hline $35 \mathrm{Zr}-15 \mathrm{Ti}$ & -- & -- & 196 & 0.36 & -- & -- \\
\hline $45 \mathrm{Zr}-5 \mathrm{Ti}$ & -- & -- & 196 & 0.71 & - & -- \\
\hline $10 \mathrm{Zr}-5 \mathrm{Mo}$ & $-\cdot$ & -- & 196 & 0.17 & -- & -- \\
\hline $35 \mathrm{Zr}-5 \mathrm{Mo}$ & -- & -- & 196 & 0.53 & -- & -- \\
\hline $45 \mathrm{Zr}-5 \mathrm{Mo}$ & -- & -- & 196 & 0.70 & -- & -- \\
\hline $35 \mathrm{Zr}-5 \mathrm{~A} 1$ & -- & -- & 196 & 0.26 & -- & -- \\
\hline $45 \mathrm{Zr}-5 \mathrm{Al}$ & -- & -- & 196 & 0.60 & -- & -- \\
\hline $10 \mathrm{Zr}-5 \mathrm{Cr}$ & -- & -- & 196 & 0.48 & -- & -- \\
\hline $45 \mathrm{Zr}-5 \mathrm{Cr}$ & -- & -- & 196 & 0.48 & -- & $-\cdot$ \\
\hline $10 \mathrm{Zr}-5 \mathrm{Fe}$ & -- & -- & 196 & 0.44 & -- & -- \\
\hline $2.5 \mathrm{~V}$ & -- & -- & 224 & 1.11 & -- & -- \\
\hline $2.0 \mathrm{~V}-2.5 \mathrm{Ti}$ & -- & -- & 196 & 0.88 & -- & -- \\
\hline $2.0 \mathrm{~V}-2.3 \mathrm{Mo}$ & -- & -- & 196 & 1.14 & -- & -- \\
\hline $2.2 \mathrm{~V}-0.54 \mathrm{Fe}$ & -- & -- & 196 & 0.54 & -- & -. \\
\hline $1.8 \mathrm{~V}-<0.02 \mathrm{Cr}$ & -- & -- & 196 & 0.41 & -- & -. \\
\hline $1.8 \mathrm{~V}-0.14 \mathrm{Al}$ & -- & -- & 196 & 0.88 & -- & -- \\
\hline $2.5 \mathrm{~V}-2.5 \mathrm{Zr}$ & -- & -- & 112 & -2.43 & -- & -- \\
\hline $2.2 \mathrm{~V}-0.87 \mathrm{Ni}$ & -- & -- & $28^{(a)}$ & -1.00 & -- & -. \\
\hline $4.0 \mathrm{~V}-2.3 \mathrm{Zr}$ & -- & -- & 196 & 0.60 & -- & - \\
\hline $5 \mathrm{~V}-25 \mathrm{Zr}$ & -- & -- & 196 & -2.84 & -- & $\cdots$ \\
\hline $5 \mathrm{~V}-35 \mathrm{Zr}$ & -- & -- & 196 & -3.52 & -- & -- \\
\hline $5 \mathrm{~V}-45 \mathrm{Zr}$ & -- & -- & 196 & 0.60 & -- & -- \\
\hline $1 \mathrm{Ce}$ & - & -- & 56 & $-11.8^{(\mathrm{a})}$ & -- & -- \\
\hline $1 \mathrm{Y}$ & -- & -- & 56 & -10.2 & -- & -- \\
\hline $5 \mathrm{Y}$ & -- & -- & 56 & -64.2 & -- & -- \\
\hline $1 \mathrm{Ni}$ & -- & -- & 28 & $0.04^{(b)}$ & -- & -- \\
\hline $2.5 \mathrm{Ni}$ & -- & -- & 7 & Broke, 7 days & -- & -- \\
\hline $5 \mathrm{Ni}$ & -- & -- & 7 & Disintegrated & -- & -- \\
\hline $1 \mathrm{Pd}$ & -- & -- & 56 & $15.7^{(a)}$ & -- & -- \\
\hline
\end{tabular}




\section{A- 11}

TABLE A-3. ('Dontinued)

\begin{tabular}{|c|c|c|c|c|c|c|}
\hline \multirow[b]{2}{*}{$\begin{array}{c}\text { Alloy Addition } \\
\text { (Balance Niobium), } \\
\text { a/o }\end{array}$} & \multicolumn{2}{|c|}{$600 \mathrm{~F}$ Water } & \multicolumn{2}{|c|}{$680 \mathrm{~F}$ Water } & \multicolumn{2}{|c|}{$750 \mathrm{~F}$ Steam } \\
\hline & $\begin{array}{l}\text { Exposure } \\
\text { Time, } \\
\text { days }\end{array}$ & $\begin{array}{l}\text { Total Weight } \\
\text { Change, } \\
\text { mg per } \mathrm{cm}^{2}\end{array}$ & $\begin{array}{l}\text { Exposure } \\
\text { 'Time, } \\
\text { days }\end{array}$ & $\begin{array}{l}\text { Total Weight } \\
\text { Change, } \\
\text { mg per } \mathrm{cm}^{2}\end{array}$ & $\begin{array}{l}\text { Exposure } \\
\text { Time, } \\
\text { days }\end{array}$ & $\begin{array}{c}\text { Total W eight } \\
\text { Change, } \\
\text { mg per } \mathrm{cm}^{2}\end{array}$ \\
\hline \multicolumn{7}{|c|}{ High-Purity Niobium, Rocking-Hearth Melts (Continued) } \\
\hline $5 \mathrm{~V}-2.5 \mathrm{Ti}$ & -- & -- & 56 & 0.51 & -- & -. \\
\hline $5 \mathrm{~V}-2.5 \mathrm{Mo}$ & -- & -- & 28 & 0.18 & -- & -- \\
\hline $5 \mathrm{~V}-2.5 \mathrm{Fe}$ & -. & -- & 28 & 0.21 & -- & -. \\
\hline $5 \mathrm{~V}-2.5 \mathrm{Cr}$ & -- & -- & 56 & 0.60 & $=$ & -- \\
\hline $5 \mathrm{~V}-2.5 \mathrm{Ni}$ & -- & $\cdots$ & 28 & 0.42 & -- & -- \\
\hline $5 \mathrm{~V}-2.5 \mathrm{~A} 1$ & -- & -- & 56 & 0.58 & -- & -- \\
\hline $2.5 \mathrm{~V}-0.5 \mathrm{C}$ & -- & -- & 28 & 0.35 & -- & -- \\
\hline $5 \mathrm{~V}-0.5 \mathrm{C}$ & -- & -- & 28 & 0.17 & -- & -- \\
\hline $2.5 \mathrm{~V}-0.25 \mathrm{Ti}-0.5 \mathrm{O}$ & -- & -- & 28 & 0.58 & -- & -- \\
\hline $5 \mathrm{~V}-0.25 \mathrm{Ti}-0.5 \mathrm{O}$ & -- & -- & 28 & 0.10 & -- & -- \\
\hline $2.5 \mathrm{~V}-0.25 \mathrm{Zr}-0.5 \mathrm{O}$ & -- & -- & 28 & 0.11 & -- & -- \\
\hline $5 \mathrm{~V}-0.25 \mathrm{Zr}-0.50$ & -- & -- & 28 & 0.32 & -- & -- \\
\hline $2.5 \mathrm{~V}-0.5 \mathrm{Ti}-0.5 \mathrm{C}$ & -- & -- & 28 & 0.12 & -- & -- \\
\hline $5 \mathrm{~V}-0.5 \mathrm{Ti}-0.5 \mathrm{C}$ & $=-$ & -- & 28 & 0.22 & -- & -- \\
\hline $2.5 \mathrm{~V}-0.5 \mathrm{Zr}-0.5 \mathrm{C}$ & -- & -- & 28 & 0.38 & -- & -- \\
\hline $5 \mathrm{~V}-0.5 \mathrm{Zr}-0.5 \mathrm{C}$ & -- & - & 28 & 0.41 & -- & -- \\
\hline $5 \mathrm{~V}$ & -. & -- & 28 & 0.29 & -- & -- \\
\hline $10 \mathrm{Zr}$ & -- & - & -- & -- & 84 & -4.30 \\
\hline $10 \mathrm{Ti}$ & -- & -- & -- & -- & 84 & 0.40 \\
\hline
\end{tabular}

(a) Off test.

(b) Losing weight. 
TABLE A-4, ELEVATED-TEMPERATURE TENSILE PROPERTIES OF NIOBIUM-BASE ALLOYS AFTER VACUUM ANNEALING AT $2190 \mathrm{~F}$

\begin{tabular}{|c|c|c|c|c|c|}
\hline \multirow[b]{2}{*}{ Alloy } & \multirow[b]{2}{*}{$\begin{array}{c}\text { Alloy Content } \\
\text { (Balance Niobium), } \\
\mathrm{a} / \mathrm{o}\end{array}$} & \multirow[b]{2}{*}{$\begin{array}{c}\text { Temperature, } \\
\text { F } \\
\end{array}$} & \multicolumn{3}{|c|}{ Tensile Properties } \\
\hline & & & $\begin{array}{l}\text { Ultimate } \\
\text { Strength, } \\
\text { psi }\end{array}$ & $\begin{array}{l}0.2 \text { Per Cent Offset } \\
\text { Yield Strength, } \\
\text { psi }\end{array}$ & $\begin{array}{l}\text { Elongation } \\
\text { in } 1 \mathrm{In} ., \\
\text { per cent }\end{array}$ \\
\hline $\mathrm{N} 40$ & $100 \mathrm{Nb}$ & 1500 & 21,000 & 16,000 & 18 \\
\hline N81 & $5 v^{(a)}$ & 1500 & 40,000 & 20,000 & 37 \\
\hline N65 & $5 \mathrm{~V}-2.5 \mathrm{Ti}(\mathrm{a})$ & 1500 & 44,000 & 23,000 & 29 \\
\hline N66 & $5 \mathrm{~V}-2.5 \mathrm{Mo}(\mathrm{a})$ & 1500 & 43,000 & 24,000 & $9(\mathrm{~b})$ \\
\hline $\mathrm{N} 72$ & $5 \mathrm{~V}-0.5 \mathrm{C}^{(\mathrm{a})}$ & 1500 & 48,000 & 30,000 & 32 \\
\hline N78 & $5 \mathrm{~V}-0.5 \mathrm{Ti}-0.5 \mathrm{C}^{(\mathrm{a})}$ & 1500 & 47,000 & 26,000 & 42 \\
\hline $\mathrm{N} 74$ & $5 \mathrm{~V}-0.25 \mathrm{Ti}-0.5 \mathrm{O}(\mathrm{a})$ & 1500 & 51,500 & 35,000 & 28 \\
\hline \multirow[t]{2}{*}{ NL11 } & $7.6 \mathrm{~V}$ & 1200 & 58,000 & 32,000 & 17 \\
\hline & & 1500 & 53,000 & 34,000 & 34 \\
\hline \multirow[t]{2}{*}{ NL12 } & $8.7 \mathrm{~V}-0.26 \mathrm{~N}$ & 1200 & 64,500 & 38,000 & 15 \\
\hline & & 1500 & 60,000 & 42,000 & 26 \\
\hline \multirow[t]{2}{*}{ NL13 } & $7.3 \mathrm{~V}-2.4 \mathrm{Ti}$ & 1200 & 62,000 & 38,000 & 14 \\
\hline & & 1500 & 53,500 & 34,000 & 23 \\
\hline \multirow[t]{2}{*}{ NL14 } & $7.6 \mathrm{~V}-2.3 \mathrm{Mo}$ & 1200 & 64,000 & 36,000 & 18 \\
\hline & & 1500 & 55,000 & 34,000 & 28 \\
\hline \multirow[t]{2}{*}{ NL2 } & $12.6 \mathrm{~V}$ & 1200 & 77,000 & 49,000 & 18 \\
\hline & & 1500 & $>69,000(c)$ & 47,000 & $>8^{(c)}$ \\
\hline
\end{tabular}

(a) Compositions nominal.

(b) Sample fractured at pinhole in shoulder.

(c) Pin in sample shoulder ruptured. 
A-13

appears as effective in improving hot strength as additions of either 2.5 a/o of titanium or molybdenum.

Creep testing of Alloys NLll through NLl4 (see Table A-4 for compositions) was completed. While these data have not yet been fully evaluated, preliminary inspection indicates that all of these alloys show good resistance to creep at $1200 \mathrm{~F}$ under a stress of 20,000 psi.

With completion of the mechanical-property evaluations, a topical report summarizing all of the results obtained on this research will be prepared. Corrosion testing of the alloys described in this report will be continued separately.

Investigation of the Creep Properties of Zircaloy-2 During Irradiation at Elevated Temperatures

F. R. Shober, P. B. Shurnaker, A. P. Young, M. F. Amateau, and R. F. Dickerson

The effect of fast-neutron (>1 Mev) irradiation on the creep properties of Zircaloy2 at elevated temperatures is to be studied by comparing total creep deformation obtained under two test conditions. Creep specimens will be stressed in the reactor and out of the reactor, and the resulting deformations will be compared. The test temperature will be $345 \mathrm{C}$. Internal-friction studies and electron microscopy of thin films of zirconium and Zircaloy -2 are being used as aids in the strain-aging studies of Zircaloy-2.

Work on an irradiation capsule to contain the creep specimens and auxiliary creep apparatus has been concerned primarily with the fabrication of components. A stress analysis of the capsule has been partially completed, and problems pertinent to the irradiation phase have been discussed with W'TR personnel.

The welded metal bellows, which form a part of the stressing assembly inside the capsules, have been shipped by the manufacturer and should arrive at Battelle early in March. They will be pressure tested prior to installation in the capsules. Delivery of the electric-heater units is scheduled for mid-March; the control instrumentation for mid-April.

At the present time, it is planned to measure the deformation with a differential transformer (suitable for in-pile applications) located below and on the low-pressure side of the bellows. The transformer core will be attached to the movable ends of the loading bellows, while the transformer will be rigidly mounted to the body of the capsule. Records of the output of the transformer in both in-pile and out-of-pile tests will provide a measure of irradiation effects on the creep properties.

During March, the fabrication of components will be continued. Present plans call for the construction of a pressure mock-up and a thermal mock-up, in addition to the inpile and out-of-pile capsules. It is probable that laboratory work with the mock-ups will begin early in April. 
$A=14$

Internal-friction studies were continued on a second lot of Zircaloy-2 at $10 \mathrm{C}$. The effect of aging time on the internal friction of strained Zircaloy- 2 was investigated during this report period. The decrease of internal friction in a Zircaloy wire with time after straining 0.5 per cent was determined. The change noted in internal friction is the typical decrease associated with the Köster effect and probably does not indicate strain aging. The specimen attained a relatively constant value of internal friction, indicating very slow recovery. Future work will consist of determining the internal friction as a function of time for strained Zircaloy-2 up to $300 \mathrm{C}$.

Tensile tests were performed at room temperature and 232,288 , and $345 \mathrm{C}$ on a second lot of Zircaloy-2 annealed $1 \mathrm{hr}$ at $750 \mathrm{C}$ in vacuum. A definite yield-point phenomenon was evident after the specimens were plastically strained, unloaded, and reloaded at temperatures of 232,288 , and $345 \mathrm{C}$. Tensile specimens were prepared from the same material used for the internal-friction studies. Upon each subsequent loading in the tensile tests, whether loaded immediately or allowed to age at the test temperature for $30 \mathrm{~min}$ before reloading, a yield point was evident. The yield point in all cases was accompanied by a perceptible drop in load which was recovered by additional straining. The rapidity with which the material changes from a material which shows no yield point to a material which does implies that a rapidly diffusing interstitial could be causing the yield points.

Electron-microscopy studies have been confined to improving chemical-polishing techniques in the preparation of thin-film specimens of zirconium and Zircaloy-2. Lightmicroscope studies will be initiated on Zircaloy- 2 which has shown the yield-point phenomenon in tensile tests. A study of the microstructure will be made with particular attention directed to the second-phase distribution and a comparison will be made with unstrained microstructures.

Determination of Oxygen in Sodium at Concentrations Below 10 PPM

D. Ensminger, D. R. Grieser, E. H. Hall, J. W. Kissel, J. McCallum, and W. H. Goldthwaite

The objective of this program is to prove the feasibility and demonstrate the practicality of a means of rapid oxygen determination in sodium. A sensitivity of \pm 1 ppm at oxygen levels of $10 \mathrm{ppm}$ and below is sought.

Novel approaches that hold promise of greater sensitivity than conventional techniques are being pursued. The initial evaluation studies are being made with "coldtrapped" sodium, 20 to $100 \mathrm{ppm}$ oxygen, to establish the basic sensitivity and handling techniques.

Ellipsometry

Effort in the use of polarimetry has been concentrated on the production of a leaktight cell containing an optically flat window. Mechanically sealed cells have been completed and are ready for receipt of sodium samples. 


\section{A- 15 and $A-16$}

Electrical Resistivity

A redesigned sodium-resistance-measuring device is virtually complete. The associated measuring equipment for the determination of resistance changes as small as 10 is under construction at present. The entire system should be completed and resistance-versus-oxygen content measurements made during the next report period.

Polarographic Studies

Recent effort has been devoted to a search for an electrolyte which is not reactive with sodium at temperatures up to about $600 \mathrm{~F}$. Many potential organics have been evaluated. Thus far all of them have failed either due to sodium reactivity or through lack of conductivity. Several promising organics remain to be evaluated.

\section{Mass Spectrometry}

The sensitivity of the mass spectrometer has been increased by the incorporation of an electron multiplier. Residual gas analyses indicate an increase in sensitivity of from 500 to 700 times.

The sodium sampling device has been checked out and proven satisfactory. The reproducibility of sample weight is being determined at present. Sodium spectrum runs and oxygen determinations will be made during the next report period.

\section{Purification-Loop Operation}

Modifications to the sodium cold-trap pisrification loop have improved operation, and samples containing oxygen levels in the 20 to $100-p p m$ range can be obtained routinely.

Wear and Friction of Sliding Surfaces in Liquid Sodium

J. W. Kissel, W. Glaeser, and W. H. Goldthwaite

Friction and wear between molybdenum ball and flat specimens, with and without sodium lubrication, have been shown to vary with preparation and conditioning of the surfaces. Correlation was subsequently found between specimen conditioning techniques and the presence of surface films having specific composition. For example, $\mathrm{MoO}_{2}$ and $\mathrm{Na}_{2} \mathrm{MoO}_{4}$ were found on surfaces which had exhibited the lowest friction and wear.

At present, vacuum-coating techniques are being developed in an effort to deposit coatings of the molybdenum-containing compounds on other base metals such as stainless steel. The thickness of such coatings will be measured, and their friction and wear properties will be determined. Friction between ball and flat steel specimens has been measured to check out the apparatus and provide baseline data. 


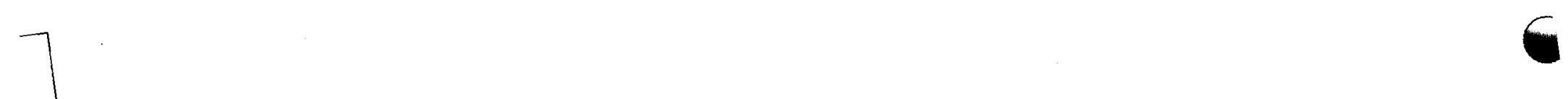

- 
B-. I

\title{
STUDIES OF FUEL A.LLOYS (AEC-DRD)
}

\author{
R. F. Dickerson
}

Niobium-base binary alloys containing 10 to $60 \mathrm{w} / \mathrm{o}$ uranium have been on test in $600 \mathrm{~F}$ water for 224 days. All specimens still exhibit a dull black oxide coating. All of the alloys have been exposed to $1500 \mathrm{~F}$ sodiurn for $500 \mathrm{hr}$ and are currently on test for another $500 \mathrm{hr}$. The niobium-10 w/o uranium alloy was tested for $1000 \mathrm{hr}$ at $1600 \mathrm{~F}$ under a stress of 40,000 psi without rupture. This specimen showed an average creep rate of 0.0002 per cent per hr. This same alloy has been tested for $300 \mathrm{hr}$ at $2200 \mathrm{~F}$ under a load of 10,000 psi with no perceptible deformation after initial loading. Tests will be run at 2200 and $2500 \mathrm{~F}$ on the niobium-20 w/o uranium alloy. Irradiationexperiment planning and capsule design are in progress, and the long-time heat treatments necessary for the gamma-immiscibility-loop study are in progress.

Melting studies designed to develop techniques for the preparation of thoriumuranium alloys containing finely divided, homogeneously disposed uranium particles are continuing. Thermodynamic studies indicate that the equilibrium nitrogen pressure for the formation of $\mathrm{ThN}$ at $3600 \mathrm{~K}$ is about $2 \mathrm{~atm}$. Thorium was arc melted once under a pressure of $2-1 / 2 \mathrm{~atm}$ of nitrogen. The resultant compound was analyzed to be $\mathrm{ThN}_{0}$. 86. Additional attempts will be made to prepare ThN by melting the thorium a number of times under 2-1/2 atm of nitrogen. Ternary additions of $1.5 \mathrm{w} / 0 \mathrm{molyb}-$ denum or $2 \mathrm{w} / 0$ niobium decrease the $600 \mathrm{C}$ secondary-creep rate of the thorium-10 $\mathrm{w} / \mathrm{o}$ uranium alloy by a factor of about 2, while the ternary addition of $10 \mathrm{w} / \mathrm{o}$ zirconium increases the creep rate of the binary thoriurn-uranium alloy.

\section{Development of Niobium-Uranium Alloys}

J. A. De Mastry, S. G. Epstein, A. A. Bauer, and R. F. Dickerson

Niobium-rich niobium-uranium alloys have potential as high-temperature metallic fuels. For this reason, a program to investigate the fabrication characteristics, mechanical and physical properties, corrosion behavior in various media, and irradiation behavior of these alloys has been undertaken.

Alloys containing from 10 to $60 \mathrm{w} / 0$ uranium were prepared from three grades of niobium, grades variously containing from 0.03 to $0.07 \mathrm{w} / 0$ oxygen and 0.02 to 0.74 w/o zirconium. No effect due to the oxygen and zirconium variations was observed on the fabrication characteristics or the tensile properties of the niobium-uranium alloys.

The testing of niobium-uranium alloys in $600 \mathrm{~F}$ water has been in progress for 224 days; the data obtained are shown in Table B-1. While the majority of the alloys being tested show total weight gains, the weight gains are now decreasing. All specimens being tested have a dull black oxide coating.

Specimens of each alloy composition have been examined after exposure to sodium at $1500 \mathrm{~F}$ for $500 \mathrm{hr}$. All specimens exhibit a dull black oxide. Table B-2 shows weight 
$\mathrm{B}-2$

TABLE B-1. CORROSION DATA FOR NIOBIUM-URANIUM ALLOYS ${ }^{(a)}$ IN 600 F W ATER

\begin{tabular}{|c|c|c|c|c|c|}
\hline \multirow{2}{*}{$\begin{array}{c}\text { Nominal } \\
\text { Alloy Content } \\
\text { (Balance Niobium), } \\
\text { w/o }\end{array}$} & \multicolumn{2}{|c|}{ Impurity Content } & \multirow{2}{*}{$\begin{array}{l}\text { Specimen } \\
\text { Condition }\end{array}$} & \multicolumn{2}{|c|}{$\begin{array}{c}\text { Total Weight Change } \\
\text { in } 600 \mathrm{~F} \text { Water, } \\
\text { mg per } \mathrm{cm}^{2}\end{array}$} \\
\hline & $\begin{array}{c}\text { Oxygen }(b) \\
\text { ppm }\end{array}$ & $\begin{array}{c}\text { Zirconium(c), } \\
\text { w/o }\end{array}$ & & In 210 Days & In 224 Days \\
\hline \multirow[t]{3}{*}{$10 \mathrm{U}$} & 680 & 0.74 & Fabricated & 0.60 & 0.63 \\
\hline & 1190 & 0.17 & Fabricated & -0.56 & -0.76 \\
\hline & 3170 & 0.02 & Fabricated & -3.08 & -3.51 \\
\hline \multirow[t]{3}{*}{$20 \mathrm{U}$} & 458 & 0.74 & Fabricated & 0.86 & 0.95 \\
\hline & 523 & 0.17 & Fabricated & 1.85 & 1.93 \\
\hline & 198 & 0.02 & Fabricated & 0.71 & 0.76 \\
\hline \multirow[t]{3}{*}{$30 \mathrm{U}$} & 586 & 0.74 & As cast & 0.15 & 0.10 \\
\hline & 669 & 0.17 & Fabricated & -2.27 & -2.32 \\
\hline & 165 & 0.02 & As cast & -0.43 & -0.59 \\
\hline \multirow[t]{3}{*}{$40 \mathrm{U}$} & 661 & 0.74 & As cast & 0.40 & 0.43 \\
\hline & 579 & 0.17 & As cast & 0.17 & 0.20 \\
\hline & 261 & 0.02 & As cast & 0.54 & 0.62 \\
\hline \multirow[t]{3}{*}{$50 \mathrm{U}$} & 375 & 0.74 & As cast & 0.27 & 0.15 \\
\hline & 334 & 0.17 & As cast & 0.34 & 0.37 \\
\hline & 271 & 0.02 & As cast & -0.38 & -0.54 \\
\hline \multirow[t]{3}{*}{$60 \mathrm{U}$} & 471 & 0.74 & As cast & -5.32 & -6.02 \\
\hline & 273 & 0.17 & As cast & -4.73 & -5.44 \\
\hline & 192 & 0.02 & As cast & -1.52 & -1.67 \\
\hline
\end{tabular}

(a) Average of duplicate specimens.

(b) Analyzed value.

(c) Nominal composition.

T ABLE B-2. CORROSION DAT A FOR NIOBIUM-URANIUM ALLOYS(a) AFTER 500 HR IN SODIUM AT $1500 \mathrm{~F}$

\begin{tabular}{|c|c|c|c|c|}
\hline \multirow{2}{*}{$\begin{array}{c}\text { Nominal } \\
\text { Alloy Content } \\
\text { (Balance Niobium), } \\
\text { w/o }\end{array}$} & \multicolumn{2}{|c|}{ Impurity Content } & \multirow[b]{2}{*}{$\begin{array}{l}\text { Specimen } \\
\text { Condition }\end{array}$} & \multirow{2}{*}{$\begin{array}{l}\text { Total weight Change } \\
\text { After } 500 \mathrm{Hr} \text { in } 1500 \mathrm{~F} \\
\text { Sodium, } \mathrm{mg} \text { per } \mathrm{cm}^{2}\end{array}$} \\
\hline & $\begin{array}{c}\text { oxygen }(\mathrm{b}), \\
\text { ppm }\end{array}$ & $\begin{array}{c}\text { Zirconium(c), } \\
\text { w/o }\end{array}$ & & \\
\hline \multirow[t]{3}{*}{$10 \mathrm{U}$} & 680 & 0.74 & Fabricated & 0.03 \\
\hline & 1190 & 0.17 & Fabricated & 0.05 \\
\hline & 3170 & 0.02 & Fabricated & -0.10 \\
\hline \multirow[t]{3}{*}{$20 \mathrm{U}$} & 458 & 0.74 & Fabricated & 0.15 \\
\hline & 523 & 0.17 & Fabricated & 0.17 \\
\hline & 198 & 0.02 & Fabricated & -0.04 \\
\hline $30 \mathrm{U}$ & 165 & 0.02 & As cast & 0.18 \\
\hline $40 \mathrm{U}$ & 261 & 0.02 & As cast & 0.55 \\
\hline $50 \mathrm{U}$ & 271 & 0.02 & As cast & 0.33 \\
\hline $60 \mathrm{U}$ & 192 & 0.02 & As cast & 0.49 \\
\hline
\end{tabular}

(a) Average of duplicate specimens.

(b) Analyzed oxygen content.

(c) Nominal composition. 
$\mathrm{B}-3$

changes after exposure. These specimens are being re-encapsulated and will be tested under the same conditions for an additional $500 \mathrm{hr}$.

Stress-rupture tests of a niobium-10 wio uranium alloy at $1600 \mathrm{~F}$ under a stress of 40,000 psi were discontinued, since the specimen did not rupture after $1000 \mathrm{hr}$. This specimen showed an average creep rate of 0.0002 per cent per $h r$; this rate includes the initial deformation on loading. A second specimen of this alloy has been loaded under a stress of $10,000 \mathrm{psi}$ at $2200 \mathrm{~F}$. This test has progressed $300 \mathrm{hr}$ with no perceptible deformation after initial loading. Upon completion of this test a specimen of the same alloy will be tested at $2500 \mathrm{~F}$. Specimens of the niobium-20 w/o uranium alloy are to be tested at $2200 \mathrm{~F}$ and $25,000 \mathrm{psi}$, and at $25010 \mathrm{~F}$ at an as yet undetermined stress. Specimens are being machined for this purposie.

Capsules are being designed for irradiation studies of niobium-10, -20 , and -30 w/o uranium alloys and two niobium-uranium-zirconium alloys. It is planned to irradiate specimens of these to approximately 1 a/o burnup at 1600 and $1800 \mathrm{~F}$.

Wire bars of binary niobium-uranium alloys are being heat treated in order to investigate the effects of oxygen on the composition limits of the gamma immiscibility loop which occurs in this system. The alloys, ranging in composition from 10 to $58 \mathrm{w} / 0$ niobium, are being heat treated at temperatus:es of 650 to $940 \mathrm{C}$ for times of 1 to 2 months. Evaluation of the phase composition limits will be made by metallographic examination. Wire bars of ternary uranium-niobium-zirconium alloys containing 50 and $60 \mathrm{w} / \mathrm{o}$ uranium have been homogenized and are being given extended heat treatments at temperatures of 500,650 , and $750 \mathrm{C}$. The effects of the zirconium additions on the niobium-uranium immiscibility gap and on the stabilization of the body-centered-cubic solid solution will be investigated in this study.

\section{Development of Thorium-Uranium Alloys}

M. S. Farkas, R. W. Endebrock, A. A. Bauer, E. L. Foster, and R. F. Ilickerson

Thorium-uranium and thorium-uranium-base alloys are being investigated with the objective of improving their irradiation stability and corrosion resistance. The effect of thorium purity, casting methods, and fabrication on the size and distribution of uranium-rich particles is being investigated. Thorium-5 to $25 \mathrm{w} / \mathrm{o}$ uranium-base ternary alloys that have been and are now being studied contain either 5 to 25 w/o zirconium or small additions of molybdenum or nicibium; quaternary alloys containing niobium and zirconium additions are also being studied. The preparation and properties of thorium and thorium-uranium carbides and nitrides are also being investigated.

Melting studies of relatively large scal $€$ melts of thorium-uranium alloys will commence when materials become available. Meanwhile, a search of the literature has continued for methods applicable to the preparation of a finely divided, homogeneously dispersed alloy of uranium in thorium. Initially the effect of various melting variables on the micro and macro homogeneity of the thorium- $10 \mathrm{w} / 0$ uranium composition will be studied. Later, the effect of small additions of niobium and molybdenum will be investigated. 
The thermodynamics of thorium-nitrogen reaction have been studied. Although only estimates of the free energy of formation of $\mathrm{ThN}$ are available, the equilibrium nitrogen pressure for the formation of $T h N$ at $3600 \mathrm{~K}$ is estimated to be about 2 atm. In a preliminary test of the preparation of $T h N$ it was found that $T h N_{0.86}$ could be obtained by melting thorium once under a pressure of $2-1 / 2 \mathrm{~atm}$ of nitrogen. X-ray analysis confirmed that the major phase present was ThN, while metallographic examination shows that the second phase present was thorium. Additional attempts to prepare ThN will be made by melting thorium several times under about 2-1/2 atm of nitrogen.

Tensile and creep tests at 600 and $700 \mathrm{C}$ are being performed on thorium $-5,-10$, and $-20 \mathrm{w} / 0$ uranium alloys and on thorium-10 w/o uranium alloys containing additions of $1.5 \mathrm{w} / 0$ molybdenum, $2 \mathrm{w} / 0$ niobium, $10 \mathrm{w} / 0$ zirconium, or $10 \mathrm{w} / 0$ zirconium-2 w/o niobium. Data obtained thus far are presented in Tables B-3 and B-4. Examination of these data show that the addition of $1.5 \mathrm{w} / 0$ molybdenum or $2 \mathrm{w} / \mathrm{o}$ niobium decreases the $600 \mathrm{C}$ secondary-creep rate of the thorium-10 w/o uranium alloy by a factor of about 2 , while the addition of $10 \mathrm{w} / 0$ zirconium increases the creep rate. However, the $600 \mathrm{C}$ tensile data show that the thorium-10 w/o uranium-10 w/o zirconium alloy is superior to the base binary alloy. Failure of this alloy to exhibit low creep rates is attributed to the fact that phase transformations occur near the test temperature.

TABLE B-3. TENSILE PROPERTIES OF THORIUM-URANIUM AND THORIUM-URANIUM-BASE ALLOYS AT 600 AND $700^{\circ} \mathrm{C}$

\begin{tabular}{|c|c|c|c|c|}
\hline $\begin{array}{c}\text { Alloy Composition } \\
\text { (Balance Thorium), w/o }\end{array}$ & $\begin{array}{c}\text { Test Temperature, } \\
\text { C }\end{array}$ & $\begin{array}{l}0.2 \text { Per Cent Offset } \\
\text { Yield Strength, psi }\end{array}$ & $\begin{array}{l}\text { Ultimate Tensile } \\
\text { Strength, psi }\end{array}$ & $\begin{array}{l}\text { Elongation, } \\
\text { per cent }\end{array}$ \\
\hline $5 \mathrm{U}$ & 600 & 11,600 & 15,950 & 44 \\
\hline $10 \mathrm{U}$ & 600 & 13,800 & 17,970 & 41 \\
\hline $20 \mathrm{U}$ & 600 & 11,200 & 15,160 & 50 \\
\hline $10 \mathrm{U}-1.5 \mathrm{Mo}$ & 600 & 11,220 & 17,710 & 43 \\
\hline $10 \mathrm{U}-2 \mathrm{Nb}$ & 600 & 12,550 & 18,000 & 37 \\
\hline $10 \mathrm{U}-10 \mathrm{Zr}$ & 600 & 19,600 & 28,400 & 44 \\
\hline $10 \mathrm{U}-10 \mathrm{Zr}-2 \mathrm{Nb}$ & 600 & 19,200 & 25,640 & 48 \\
\hline $5 \mathrm{U}$ & 700 & 6,590 & 11,700 & 51 \\
\hline $10 \mathrm{U}$ & 700 & 8,800 & 10,300 & 44 \\
\hline $20 \mathrm{U}$ & 700 & 6,710 & 8,170 & 58 \\
\hline $10 \mathrm{U}-2 \mathrm{Nb}$ & 700 & 8,450 & 10,800 & 66 \\
\hline $10 \mathrm{U}-10 \mathrm{Zr}-2 \mathrm{Nb}$ & 700 & 12,100 & 13,910 & 77 \\
\hline
\end{tabular}

TABLE B-4. CREEP PROPERTIES OF THORIUM-URANIUM AND THORIUM-URANIUM-BASE ALLOYS AT $600 \mathrm{C}$

\begin{tabular}{cccc}
\hline $\begin{array}{c}\text { Alloy Composition } \\
\text { (Balance Thorium), w/o }\end{array}$ & $\begin{array}{c}\text { Stress, } \\
\text { psi }\end{array}$ & $\begin{array}{c}\text { Minimum Creep Rate, } \\
\text { per cent per hr }\end{array}$ & $\begin{array}{c}\text { Elongation, } \\
\text { per cent }\end{array}$ \\
\hline $5 \mathrm{U}$ & 3500 & 0.0007 & $\cdots$ \\
$10 \mathrm{U}$ & 1500 & 0.0028 & -- \\
$10 \mathrm{U}$ & 3500 & 0.0100 & 3.2 \\
$10 \mathrm{U}$ & 4000 & 0.0135 & -- \\
$20 \mathrm{U}$ & 1500 & 0.0014 & -- \\
$20 \mathrm{U}$ & 3500 & 0.0126 & -- \\
$10 \mathrm{U}-1.5 \mathrm{Mo}$ & 3500 & 0.0013 & -- \\
$10 \mathrm{U}-1.5 \mathrm{Mo}$ & 5500 & 0.0085 & 2.6 \\
$10 \mathrm{U}-2 \mathrm{Nb}$ & 3500 & 0.00174 & 1.0 \\
$10 \mathrm{U}-2 \mathrm{Nb}$ & 7000 & 0.0625 & 12.63 \\
$10 \mathrm{U}-10 \mathrm{Zr}$ & 3500 & 0.037 & 7.2 \\
\hline
\end{tabular}




\section{$\mathrm{C}-1$}

FISSION-GAS RELEASE FROM REFRACTORY FUELS (AEC-DRD)

J. B. Melehan, D. A. Vaughan, R. H. Barnes, H. Sheets, S. D. Beck, and F. A. Rough

Various aspects of a basic program of study of release of fission products from $\mathrm{UO}_{2}$ are reported in this section. The objective is to understand releases from sintered $\mathrm{UO}_{2}$; thus, in-pile study of sintered material is being initiated, and supporting studies of diffusion and of characterization are in progress.

Characterization of Sintered $\mathrm{UO}_{2}$ and Model of Gas Release

The pore size, pore distribution, and grain size are being evaluated for specific $\mathrm{UO} 2$ bodies to aid in interpreting the fission-gas release rates during irradiation and postirradiation heat treatment. Two specimens from a batch of sintered $\mathrm{UO}_{2}$ have been examined for pore size and distribution in the as-polished condition. The sintering treatments were a 15-hr ball milling, a 40,000-psi forming pressure, and a 1-hr sinter at $2800 \mathrm{~F}$ in hydrogen. The density was measured pycnometrically to be 95.8 per cent of theoretical. The surface area of this lot of specimens, as determinedby nitrogen adsorption, was found to be $410 \mathrm{~cm}^{2}$ per $\mathrm{g}$, or $4480 \mathrm{~cm}^{2}$ per $\mathrm{cm}^{3}$. This large surface area for 95 per cent dense bodies was surprising. Recent microporosity analysis has indicated a large error in the density as measured pycnometrically. For the two bodies examined, pore fractions of 0.21 and 0.18 were obtained by lineal analysis which included only those pores larger than $3 \mu$. Thus, it would appear that the density of this lot is approximately 80 per cent of theoretical rather than 95. 8. Based upon this pore measurement, the surface area, due to pores, was computed to be $\cong 30 \mathrm{~cm}^{2}$ per $\mathrm{cm}^{3}$, where the average pore diameter is $9 \mu$ and the mean free path between pores is $30 \mu$. It would appear from this analysis, that the high surface area, as obtained by the BET method, for this case cannot be attributed to the large pore volume of these specimens. Smaller pores in these specimens are being analyzed by microscopic methords using higher magnification. Also, during the next period, attempts will be made to separate grain-boundary pores frorn intragranular pores. In this latter investigation, the grain-boundary surface area will be determined, since it is possible that the high surface area might be due to grain-boundary surface adsorption of nitrogen.

Also, during this period, five groups of specimens were prepared for study that are expected to exhibit wide differences in total surface area, as determined by the BET method. This was accomplished by selectively altering fabrication conditions.

Fabrication conditions, densities, porosities, and oxygen-to-uranium ratios of the five groups of specimens, are shown in Table C-1. Note that porosity measurements were made by xylene adsorption. It would be expected that some of the porosity that is closed to xylene will be open to nitrogen. Examination of polished sections of representative specimens is planned.

Future work also will include an investigation of the effect of sintering conditions (time, temperature, and atmosphere) on the density, oxygen-to-uranium ratio, and 


\section{$\mathrm{C}-2$}

microstructure of $\mathrm{UO}_{2}$ pellets made from oxidized $\mathrm{UO}_{2}$. Additional specimens will be made for surface-area measurements.

A preirradiation examination of four preparations of $\mathrm{UO}_{2}$ (two sintered bodies, a fused $\mathrm{UO}_{2}$, and a single crystal) has been completed on a second series of specimens. This series is being irradiated in the as-polished condition to determine the effects of irradiation upon surfaces. Light and electron metallographic studies will be made after irradiation, and the results will be compared with the results of the preirradiation examination of these specimens and with those of the previous study of surface changes during irradiation.

\section{Diffusion in $\mathrm{UO}_{2}$}

The experimental study of fission-gas release from uranium dioxide during postirradiation heat treatment is continuing.

During February, measurements of fission-gas release from a $1.57-\mathrm{g}$ flat plate of single-crystal $\mathrm{UO}_{2}$ were made at $1205 \mathrm{C}$. The plate was irradiated for $16 \mathrm{hr}$ in an estimated effective thermal-neutron flux of $1 \times 10^{13} \mathrm{nv}$. The results are being analyzed.

Measurements of the release rates of fission gases from additional plates of single-crystal $\mathrm{UO}_{2}$ in the range of 1200 to $1500 \mathrm{C}$ are scheduled to continue.

\section{Preparation for In-Pile Study}

The apparatus for in-pile study of fission-product release from $\mathrm{UO}_{2}$ has been reinserted into the $B R R$, but difficulties with the air-monitoring system developed; the se difficulties are being corrected. It is anticipated that actual operation at temperature will begin soon.

For these in-pile studies, diffusion-type releases of fission gas can best be measured and understood when an equilibrium is established for a nuclide at a given temperature. Ideally, at equilibrium, the concentration pattern reaches a steady state, and the rate of release is a constant fraction of the rate of production. For spherical geometry, this fraction is a function of the dimensionless parameter $\mu$ only, assuming a constant rate of production of the nuclide and assuming that no diffusion of the precursor occurs:

where

$$
\begin{aligned}
\mu & =a^{2} \lambda / D \\
a & =\text { equivalent sphere radius, } \mathrm{cm} \\
\lambda & =\text { decay constant, } \mathrm{sec}^{-1} \\
D & =\text { diffusion coefficient, } \mathrm{cm}^{2} \text { per sec. }
\end{aligned}
$$




\section{$\mathrm{C}-3$ and $\mathrm{C}-4$}

Equations have also been derived for spherical geometry describing the ratio of the rate of release to the rate of production for the case where the precursor diffuses. The results are expressed as a function of $\mu_{1}$ and $\mu_{2}$, which are the dimensionless parameters (defined above) for the parent and daughter nuclides, respectively.

TABLE C-1. FABRICATION CONDITIONS, DENSITIES, POROSITIES, AND OXYGEN-TO-URANIUM RATIO OF UO SPECIMENS $^{2}$

\begin{tabular}{|c|c|c|c|c|c|c|c|c|c|}
\hline \multirow[b]{3}{*}{ Specimen } & \multicolumn{4}{|c|}{ Fabrication Conditions } & \multicolumn{4}{|c|}{ Density and Porosity(a) } & \multirow{3}{*}{$\begin{array}{l}\text { Oxygen-to } \\
\text { Uranium } \\
\text { Ratio }\end{array}$} \\
\hline & \multirow{2}{*}{$\begin{array}{l}\text { Ball- } \\
\text { Milling } \\
\text { Time, } \\
\text { hr }\end{array}$} & \multirow{2}{*}{$\begin{array}{c}\text { Preoxidation } \\
\text { Temperature, } \\
\text { F }\end{array}$} & \multirow{2}{*}{$\begin{array}{c}\text { Forming } \\
\text { Pressure, } \\
\text { psi }\end{array}$} & \multirow[b]{2}{*}{$\begin{array}{l}\text { Sintering } \\
\text { Temperature, } F\end{array}$} & \multicolumn{2}{|c|}{ Bulk Density } & \multicolumn{2}{|c|}{$\begin{array}{l}\text { Porosity, } \\
\text { per cent }\end{array}$} & \\
\hline & & & & & $\mathrm{G}$ per $\mathrm{Cm}^{3}$ & $\begin{array}{l}\text { Per Cent of } \\
\text { Theoretical }\end{array}$ & $\begin{array}{l}\text { Open } \\
\text { Pores }\end{array}$ & $\begin{array}{l}\text { Closed } \\
\text { Pores }\end{array}$ & \\
\hline $79-26$ & 2 & -- & 40,000 & 2600 & 10.17 & 92.6 & 0 & 8.4 & 2.00 \\
\hline $79-28$ & 2 & -- & 40,000 & 2800 & 10.38 & 94.5 & 0 & 5.5 & 2.00 \\
\hline $79-30$ & 2 & -- & 40,000 & 3000 & 10.38 & 94.5 & 0 & 5.5 & 2.00 \\
\hline 80 & 15 & -- & 20,000 & 3000 & 10.58 & 96.3 & 0 & 3.7 & 2.01 \\
\hline 81 & 15 & 1000 & 20,000 & 3000 & 10.58 & 36.3 & 0 & 3.7 & 2.00 \\
\hline
\end{tabular}

(a) Densities and porosities are the average of measurements on three pellets, and were measured by xylene immersion. Theoretical density of $\mathrm{UO}_{2}$ was taken as $10.98 \mathrm{~g}_{\text {per }} \mathrm{cm}^{3}$. 

.

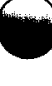

$$
\text { (1) }
$$

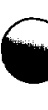


D-.1

GENERAL FUEL-ELEMENT DEVELOPMENT (AEC-DRD)

\author{
S. J. Paprocki
}

Techniques are being developed for the fabrication of dense cermet-type fuel materials consisting of a mixture of 80 volume per cent $\mathrm{UO}_{2}$ and 20 volume per cent metal. Stainless steel, chromium, molybdenum, and niobium metal matrices are being investigated. The properties of the cermet fuels are being characterized by evaluation of structure and determination of physical and mechanical properties.

A study is being conducted concerned with the solid-phase bonding of molybdenum and niobium. Techniques have been developed for the self-bonding of niobium, and the process is being applied to the fabrication of niobium-clad compartmented $\mathrm{UO}_{2}$ fuel plates and as semblies.

The kinetics involved in a solid-phase pressure-bonding process are being investigated. A study is being made to determine the effects of metal structure, surface roughness, and bonding parameters of time, temperature, and pressure on the subsequent area of contact and bond characteristics.

\title{
Fabrication of Cermet Fuel Elements
}

S. J. Paprocki, D. L. Keller, G. W. Cunningham, and D. E. Kizer

Currently pressure bonding is being used to fabricate cermets for thermalconductivity, mean linear thermal-expansion, electrical-resistivity, modulus-ofrupture, and thermal-shock-resistance measurements. Matrix materials include stainless steel, chromium, molybdenum, and niobium.

Cermet rods of 80 volume per cent $\mathrm{UO}_{2}$ dispersed in the various matrix materials have been pressure bonded to 90 per cent of theoretical density or greater. Caps of iron, silver, and solder have been placed on the ends of the rods in preparation for thermal-conductivity measurements. Measurements have been made to $800 \mathrm{C}$ on two of the rods; however, an analysis of the data has not been made at this time.

Five cores each of 80 volume per cent $\mathrm{UO}_{2}$-chromium and -niobium have been pressure bonded for $3 \mathrm{hr}$ at $10,000 \mathrm{psi}$, at temperatures ranging from 1900 to $2200 \mathrm{~F}$. Machining of the cores into specimens for modulus-of-rupture measurements was impossible due to the low density achieved by puessure bonding at the se temperatures. Additional cores are being prepared for pressure bonding at higher temperatures in an attempt to obtain cermet cores of 90 per cent of theoretical density or greater. In addition, 1 by 1 by 0.100 -in. 80 volume per cent $\mathrm{UO}_{2}$-molybdenum and -stainless steel cermet cores have been prepared for pressure bonding for $3 \mathrm{hr}$ at $10,000 \mathrm{psi}$ at temperatures ranging from 2250 to $2350 \mathrm{~F}$. After pressure bonding, specimens 0.085 by $0.150 \mathrm{in.}$ will be machined from the cores for modulus-of-rupture measurements. 
Gas-Pressure Bonding of Molybdenum-and Niobium-Clad Fuel Elements

S. J. Paprocki, E. S. Hodge, and P. J. Gripshover

Fabrication of molybdenum- and niobium-clad fuel elements containing ceramic and cermet fuels is being studied. Investigations are directed toward determination of suitable bonding conditions to produce strong metallurgical bonds in fuel elements of various configurations. Evaluation of specimens is based on the quality of bond obtained and the properties of the cladding material after bonding.

The studies during the past report period have been primarily concerned with the development of niobium-clad fuel elements. Specimens have been prepared and evaluated to determine the relative merit of various materials as spacer materials that can later be dissolved out of assemblies to form coolant channels. These included graphitecoated molybdenum, graphite-coated Ti-Namel, magnesium oxide, molybdenum, uranium dioixde, Vycor, and window glass. Chemical analyses were made to determine if any increase in impurity level of the niobium was introduced by the barrier material. Results of these tests indicated that uranium dioxide was the only material which did not change the chemical composition of the niobium during bonding. Magnesia, Vycor, and window glass raised the oxygen content to an unacceptable level, while the molybdenum alloyed with the niobium specimen, causing severe embrittlement. Results with the graphite-coated specimens indicated the carbon content was increased approximately $100 \mathrm{ppm}$ during bonding; furthermore, they showed that the coating must be much thicker on the $\mathrm{Ti}-\mathrm{Namel}$ because of the rapid diffusion of carbon into iron at the se temperatures. The introduction of the carbide phase into the microstructure is not desirable, however, and carbon does not appear to be satisfactory as a barrier material unless the bonding time can be shortened to minimize carbon diffusion.

In an effort to determine the strength of the niobium-to-niobium bonds formed at optimum bonding parameters, two flat-plate tensile specimens have been prepared for evaluation. One specimen, a control, consisted of a single plate 0.100 in. thick by $0.5 \mathrm{in}$. wide by $8 \mathrm{in}$. long; the second specimen consisted of two plates 0.1002 by 0.5 by 4 in. which were butt bonded to form a single 8 -in. -long plate. Both specimens were subjected to bonding conditions of $2100 \mathrm{~F}$ and $10,000 \mathrm{psi}$ for $3 \mathrm{hr}$. After bonding, a metallographic examination was made of the butt bond. It was noted that some lack of grain growth had occurred in some areas, which is not characteristic of the bonds normally achieved. Both specimens were pulled in tension until fracture occurred. The control specimen fractured at a load of $1990 \mathrm{lb}$ with considerable necking before fracture. The butt-bonded specimen fractured in the bond area under a load of $1850 \mathrm{lb}$ with some necking. Some separation occurred at the edge of the tensile specimen under lighter loads. It is significant to note, however, that necking did occur in the center of the bond area, indicating that area was well bonded. Tensile tests are being repeated using rod-type specimens which may give more reliable data. 
$\mathrm{D}-3$

Factors Affecting Fressure Bonding

J. W. Spretnak and $C_{i}$. W. Cunningham

The mechanism and kinetics of solid-phase bonding of metals under application of heat and pressure are being studied. One phase of the program involves an investigation of the relationship between hot hardness and bonding pressure. Specimens are prepared for evaluation by hot pressing a 500-rms surlace of OFHC copper in contact with an 8-rms OFHC copper surface. A total time of: less than 1 min is required to apply and release the desired load. This short time is used so that the bonding time will be comparable with that used in obtaining hot-hardness values.

Specimens have been prepared by applying pressures of 2000 to 24,000 psi at temperatures of $200,400,600$, and $700 \mathrm{~F}$. Comparison of pressure used with values of Vickers hardness expressed in psi indicates that apparent contact between the surface of the two metals is reached at pressures of approximately 5 to 10 per cent of the hot hardness. Apparent contact is used to describe the condition such that after polishing and etching very lightly that a bond line can be detected, but no voids are visible under the light microscope.

Metallographic examinations show that the bond lines produced by low pressures do not have uniform etching characteristics. The bond line produced at the points of initial contact etches more rapidly but does not greatly differ in appearance from that of an ordinary grain boundary. Along the areas which were the last to be pressed into contact and thus the areas which were pressed at the lowest pressure, etching is very rapid, and, after a prolonged time, wide, deep holes which follow the contour of the bond interface are produced. As bonding pressures are increased, these areas decrease, and etching becomes more uniform along the bond line. Pressures of approximately 75 per cent of the hot hardness are required to provide a uniform bond line.

This etching behavior suggests that, in areas where low bonding pressures are obtained, very few atoms on the two surfaces are close enough to be involved in bonding, and thus etching occurs almost as rapidly as on two free surfaces. Annealing studies also support this opinion. Sections of specimens bonded at $700 \mathrm{~F}$ and pressures of $4,000,12,000$, and $24,000 \mathrm{psi}$ were annealed $15 \mathrm{hr}$ at $1000 \mathrm{C}$. After polishing and light etching, large bond-line areas of the 4,000-psi specimen were found to be not in contact. More of the area was in contact in the 12,000-psi specimen, and nearly all the area was in contact in the 24,000-psi specimen. No grain growth across the interface could be observed in the 4,000- and 12,000-psi specinens, but grain growth across 10 to 20 per cent of the bond interface could be detected on the 24,000-psi specimen. The separation of the bond line in particular areas during annealing suggests that weak bonds were formed during the initial application of pressure, but that the se bonds were broken during high-temperature annealing in an effort to minimize surface energy.

Sections of the $700 \mathrm{~F}$ series have also been used to prepare diffusion couples with a copper $-4 \mathrm{w} / \mathrm{o}$ silver alloy. The diffusion of silver along the bond line and grain boundaries will be studied to obtain information on the nature of the bond line as related to applied pressure. 


$$
\mathrm{D}-4
$$

Specimens are being prepared to study the effect of pressure at higher temperatures $(1000,1200$, and $1400 \mathrm{~F})$. The effect of grain size will also be studied at 400 , 700 , and $1000 \mathrm{~F}$. 


\author{
E-1 \\ GAS-PRESSURE BONDING OF CERAMIC, CERMET, \\ AND DISPERSION FUIEL ELEMENTS \\ (AEC-FUEL CYCLE)
}

\author{
S. J. Paprocki, S. W. Porembkä, D. L. Keller, E. S. Hodge, \\ C. B. Boyer, and J. B. Fox
}

This study is concerned with the development of a fuel-element fabrication process which will maintain or improve quality while reducing manufacturing costs. The gaspressure-bonding method is being investigated since it appears to be a likely method for achieving'these objectives. The fuel systems being evaluated in this program include the ceramic, cermet, and dispersion fuels with a major emphasis on the ceramic fuel system. It is anticipated that such fuel systerns will offer the greatest promise of high burnups over a range of operating temperatures. The program is directed toward the simultaneous densification of powder fuels ancl cladding with stainless steel.

\title{
Uranium Dioxide Compaction Studies
}

Compaction studies of the uranium dioxide powders are based on the development of high-density green compacts which will subsequently achieve a desired range of densities during pressure bonding. Previous studies of $\mathrm{UO}_{2}$ compaction involved the cold-pressing characteristics and tap densities of seven commercial powder types and several powder mixtures, centrifugal packing, ultrasonic compacting, presintering, binder removal, and the effect of stoichiometry. At the present, investigations on the effects of particle-size range and the effects of mixtures of $\mathrm{UO}_{2}$ on the attainable pressure-bonded density are in progress.

The effect of adding ceramic grade uranium dioxide to both the fused and special dense oxides was investigated. The object of this approach was to achieve the major part of densification during pressure bonding with the ceramic grade material. The results, which are given in Table E-1, do not show a definite density trend with the amount of ceramic grade addition, although the highest density was attained with a $25 \mathrm{w} / \mathrm{o}$ ceramic grade addition to the fused uranium dioxide. In general, higher pressurebonded densities were achieved than those previously attained with the as-received fused and special dense powders.

Flash roasting to attain off-stoichiometry uranium dioxide powders is being studied as a possible means of activating the powders prior, to pressure bonding. Previous tests have shown that the off-stoichiometry powders return to stoichiometry during the pressure-bonding operation. The results of initial flash-roasting tests with the special dense oxide are given in Table E- 2 . In addition to flash roasting of the fused oxides, further work will involve the compact:ing and pressure-bonding characteristics of such powders. 


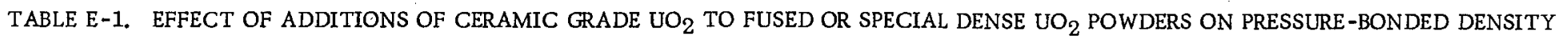

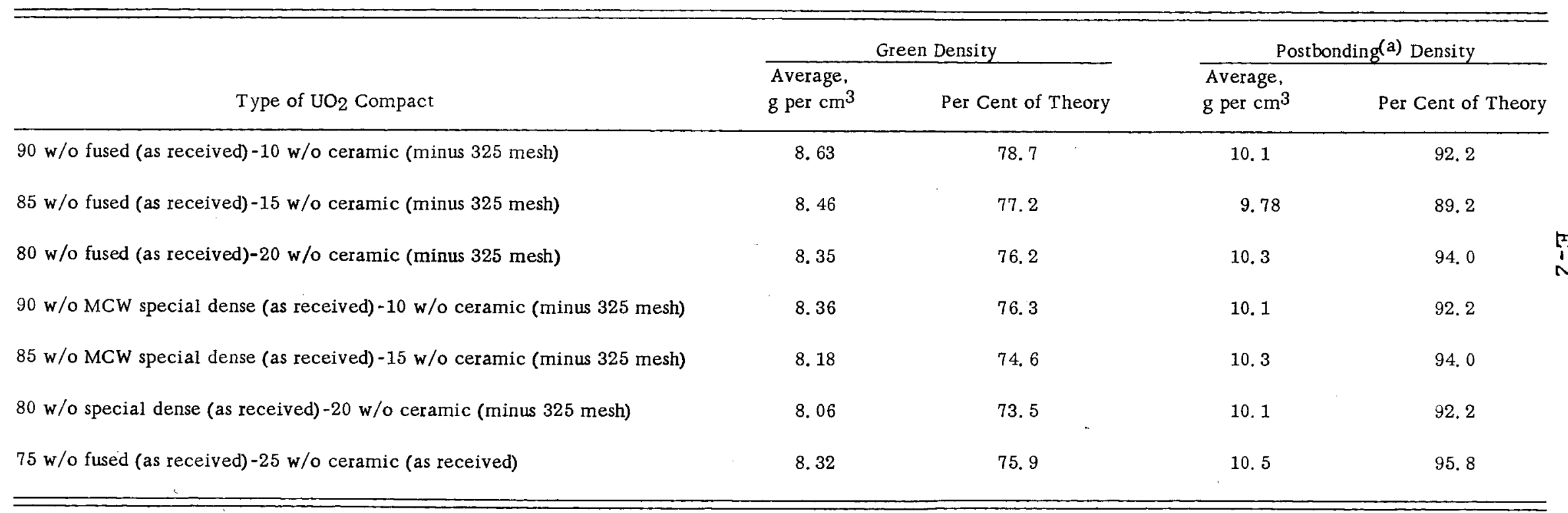

(a) Bonding conditions for all compacts: $3 \mathrm{hr}$ at $2100 \mathrm{~F}$ and 10,000 psi. 
E- 3 and: E-4

TABLE E-2. EFFECT OF FLASH ROASTING ON UO 2 STOICHIOMETRY

\begin{tabular}{lccc}
\hline & \multicolumn{2}{c}{ Heat-Treating Data } & \\
\cline { 2 - 4 } Sample (a) & Time, min & Temperature, F & Oxygen-to-Uranium Ratio \\
\hline SD-3 & 5 & 400 & 2.02 \\
SD-6 & 5 & 450 & 2.01 \\
SD-9 & 5 & 500 & 2.02 \\
SD-12 & 5 & 550 & 2.04 \\
SD-15 & 5 & 600 & 2.08 \\
SD-18 & 5 & 650 & 2.09 \\
SD-20 & 2 & 700 & 2.05 \\
SD-21 & 5 & 700 & 2.22 \\
& & & \\
\hline
\end{tabular}

(a) All samples were special dense $\mathrm{UO}_{2}$ with an oxygen-to-uranium ratio of 2.00.

Gas-Pressure Bonding

Included in the gas-pressure-bonding studies is the determination of the densification, permeability, and thermal-conductivity characteristics of various types and combinations of $\mathrm{UO}_{2}$ powders in the form of both tapped powders and cold-pressed pellets. Investigations are being conducted to evaluate various fuel-element shapes for the simultaneous densification and cladding of the $\mathrm{UO}_{2}$ powders. Also under study are various fuel-element shapes containing high-clensity $\mathrm{UO}_{2}$ which lend themselves to pressure bonding and which cannot be produced by other conventional fabrication methods.

Several tubes of both cold-pressed pellets and tap-packed powders of various types of $\mathrm{UO}_{2}$ were pressure bonded. These were prepared to evaluate different pressure-bonding cycles with identical specimens, establish the effect of selectparticlesize mixtures upon densification, and produce permeability and the rmal-conductivity test specimens. These specimens are in process of being evaluated.

In a process using powdered stainless steel for a spacer material and for end plugs, it was demonstrated that the stainless steel can be densified to 97.3 per cent of theoretical during pressure bonding. Further work will be aimed at matching the consolidation of the stainless steel powder components to that of the uranium dioxide fuel. 
6

○ 


\author{
$F-1$ \\ DEVELOPMENT OF URANIUM CARBIDE (AEC-FUEL CYCLE)
}

F. A. Rough and W. Chubb

As part of the USAEC Fuel-Cycle Development Program, research on the preparation and properties of uranium carbides is in progress. This program includes investigations of the preparation and forming of uranium carbides by powder metallurgical and by melting and casting techniques. The mechanical, physical, and chemical corrosion and compatibility characteristics of uranium carbides and their alloys are being determined. A study of diffusion rates in the uranium carbides has been undertaken, and an effort is being made to understand the nature of irradiation-damage processes in carbides.

Data reported during the first 10 months of research have included information on the variation of density and resistivity with composition, information on the compatibility of carbides with common metals, strength data, and diffusivity data. In addition, the arc-casting process has been scaled up to produce 5-kg castings, and alloys of uranium monocarbide have been found which show increased strength and corrosion resistance.

Work during the last month resulted in a compact pressed and sintered to 89 per cent of theoretical density at a composition of approximately $6 \mathrm{w} / 0$ carbon. A series of castings $3 / 4$ in. in diameter and 8 in. long has been prepared by skull casting and has been found to contain between 4.78 and $5.26 \mathrm{w} / 0$ carbon. This indicates considerable progress in compositional control in the skull-casting process.

Four compression tests on uranium $-4.8 \mathrm{w} / \mathrm{o}$ carbon alloys yielded an average compressive strength of $54,100 \mathrm{psi}$. This is in excellent agreement with the previously reported value of $54,500 \mathrm{psi}$. Two compression tests on uranium-7.0 w/o carbon alloys gave an average compressive strength of 78,300 psi. This increased strength at this composition is in agreement with the trend indicated by hardness data.

Data on the rate of self-diffusion of uranium in uranium monocarbide indicate that the rates of self-diffusion of uranium ir. uranium monocarbide are over 100 times lower than the rates of interdiffusion of uranium and carbon in the carbide. By implication, carbon must diffuse much faster than uranium in the se carbides.

\title{
Alternate Fabrication Methods for UC
}

S. J. Paprocki, D. L. Keller, D. E. Kizer, and J. M. Fackelmann

Various techniques are being studied for producing UC powder and dense UC compacts by methods other than arc melting. The reaction of fine uranium powder with methane or propane has been accomplished at 700 and $540 \mathrm{C}$, respectively, to produce fine UC powder of near stoichiometric composition. The methane reaction 
$\mathrm{F}-2$

yields a product containing $\mathrm{UC}_{2}$ and a small quantity of an unknown as determined by $\mathrm{X}-\mathrm{ray}$ diffraction. The propane reaction product has a very strong but diffuse pattern of UC, showing no $U_{2}$ nor alpha uranium, and a small quantity of an unknown. Recently, the reaction of these alkanes with uranium has been studied in an apparatus employing a stagnant partial pressure of alkane gas and hydrogen. The partial pressure of hydrogen in the system has been varied from $40 \mathrm{~mm}$ of mercury to $0.7 \times 10^{-3} \mathrm{~mm}$ of mercury with no marked effect upon the rate of reaction with methane or propane. Also, increasing the reaction temperature by $100 \mathrm{C}$ has had no marked effect upon the rate of reaction with methane and propane. The apparatus is being modified to pass the alkane gas over the uranium in an attempt to increase the reaction rate.

Uranium carbide powders produced by the uranium-methane reaction were sintered $1 \mathrm{hr}$ in vacuo at a temperature of $1950 \mathrm{C}$. The average density increased from 7.62 to $11.17 \mathrm{~g}$ per $\mathrm{cm}^{3}$. This powder, containing $5.98 \mathrm{w} / 0$ total carbon, was described in BMI-1409. As may be seen by comparing these data with previously reported data, raising the sintering temperature from 1900 to $1950 \mathrm{C}$ has little effect on densification.

Compacts of UC mixed with 15 volume per cent of metallic chromium have been sintered at 1800 and $1900 \mathrm{C}$ to help understand the effect of a liquid phase on the densification of these compacts. No bulk-density measurements could be made because the specimens fractured during the heat treatment; however, these specimens will be examined metallographically and chemically in an effort to obtain useful information.

In addition, samples of uranium hydride plus $5 \mathrm{w} / \mathrm{o}$ carbon are being vacuum hot pressed in an attempt to achieve a high green density. These compacts will then be reacted at higher temperatures to form UC.

Melting and Casting Techniques for Uranium-Carbon Alloys

B. C. Boesser, W. M. Phillips, E. L. Foster, and R. F. Dickerson

Reliable techniques for the production of high-quality cast shapes of uranium carbide are being developed. Large cast shapes of uranium carbide currently are being prepared by skull-type arc melting.

As reported previously, it has been determined that the major difficulty in attaining compositional control is segregation in the carbide skull in which the melts are made. Improvements in charging practices and melting techniques have decreased this segregation, although samples taken from several spots in the skull showed carbon compositions from 4.5 to $5.6 \mathrm{w} / \mathrm{o}$. The improvement in skull homogeneity is demonstrated by the analyses of castings produced this month. Several 2-in. -diameter by 8 -in. -long castings were cast into cold molds and found to be homogeneous and sound and to possess carbon contents ranging from 4.3 to $5.3 \mathrm{w} / \mathrm{o}$. Even better compositional control was attained in a number of 3/4-in. -diameter by 8 -in. -long ingots that incidentally were cast in molds heated to $2200 \mathrm{~F}$. These castings were sound and homogeneous and possessed very good surfaces. These ingots ranged in composition from 4.78 to $5.26 \mathrm{w} /$ o carbon. 


\section{$\mathrm{F}-3$}

The remaining apparent lack of composition control may be attributable to skull inhomogeneities and to variable pickup of carbon from the electrode tip.

Research during the next month will involve the production of $3 / 4$-in. -diameter by 8-in. -long cylindrical shapes of uranium carbide with a nominal content of $5 \mathrm{w} / 0$ carbon. The realization of compositional control will be sought by homogenization of the skull, by standardization of melting times, and by study of the effect of atmospheres on electrode-tip erosion and the gas content of the cast shapes.

Metallurgical and Engineering Prcperties of Uranium Monocarbide

W. M. Phillips, W. L. Foster, and R. F. Dickerson

Uranium carbide is being studied in terms of such properties as density, resistivity, thermal conductivity, strength, and corrosion resistance. To both define and improve the characteristics of this material, the variables of impurity content, carbon content, alloy content, and heat treatment are being evaluated in relation to the above properties.

Previous work has indicated that additions of molybdenum, niobium, and tantalum to uranium monocarbide result in a considerable increase in strength, while additions of the carbides of molybdenum, titanium, and vanadium increase the corrosion resistance of uranium monocarbide in Santowax. Specimens of both the monocarbide and sesquicarbide containing 1, 5, 10, or $20 \mathrm{w} / \mathrm{o}$ additions of metal and their carbides are currently undergoing physical, mechanical, and corrosion testing.

As shown by Table F-l, the average transverse rupture strengths of the uraniumcarbon binary alloys are considerably less than the compressive rupture strengths. It has been observed that the transverse rupture strength tends to decrease as the time between machining and testing is increased. This observation suggests that the transverse rupture strengths shown in Table F-l may be highly dependent upon the surface condition of the specimens.

It is hoped that current tests on uranium carbide containing ternary metal additions will show whether the apparent strength increase in transverse rupture testing is a true strength increase or is a phenomenon resulting from a reduction or elimination of surface microcracking. As part of the above program, determinations of the modulus of elasticity and strain at rupture are being made.

\section{Uranium Monocarbide Diffusion Studies}

W. Chubb, R. W. Getz, and F. A. Rough

The rate of self-diffusion of uranium in uranium monocarbide is being studied using a tracer technique. Interest in diffusior rates in uranium monocarbide is based 
TABLE F-1. STRENGTH OF UC AND $\mathrm{U}_{2} \mathrm{C}_{3}$

\begin{tabular}{ccc}
\hline Material & $\begin{array}{c}\text { Average } \\
\text { Transverse } \\
\text { Strength, psi }\end{array}$ & $\begin{array}{c}\text { Average }{ }^{(\mathrm{b})} \\
\text { Compressive } \\
\text { Strength, psi }\end{array}$ \\
\hline U-4.7 w/o C & 7,400 & -- \\
U-4.8 w/o C & 8,900 & 54,100 \\
U-4.9 w/o C & 5,500 & -- \\
U-7.0 w/o C & 13,300 & 78,300 \\
\hline \hline
\end{tabular}

(a) At least four tests run at each composition.

(b) Four test were run on $4.8 \mathrm{w} / \mathrm{o}$ carbon specimens; two tests were run on 7.0 w/o carbon specimens.

on the consideration being given this material as a reactor fuel for high-temperature operation. Earlier in the study the rate of interdiffusion of uranium and carbon in uranium carbide was determined between 1600 and $2000 \mathrm{C}$. The techniques needed for measuring the self-diffusion rate of uranium in uranium monocarbide have been tested, and diffusion couples of uranium monocarbide have been analyzed. The analyses of the se couples indicate that the self-diffusion coefficient for uranium in uranium monocarbide is about 100 times less than the interdiffusion coefficient determined previously. Currently, additional diffusion couples are being prepared and evaluated.

Diffusion couples for the current study are prepared by placing a 0.001 -in. -thick metal foil of enriched uranium (93 per cent uranium-235) between two 0.25 -in. -lengths of depleted uranium (0.04 per cent uranium-235) monocarbide rod. Preparation of couples for annealing includes wrapping the couple in tantalum foil and placing it in a degassed graphite $\mathrm{jig}$ for a bonding operation of $4 \mathrm{hr}$ at $1400 \mathrm{C}$. After annealing for a suitable length of time at a higher temperature, the couple is sampled for analysis of uranium-2 35 by grinding the couple on 600 -grit silicon carbide powder in the presence of a small amount of $0.1 \mathrm{~N}$ nitric acid solution.

In a diffusion couple annealed for $120 \mathrm{~min}$ at $2000 \mathrm{C}$, a diffusion zone approximately 0.018 in. in width was formed. Measurement of the uranium-235 present in the individual samples from this couple was obtained by measuring their gross gamma activity. It has been found that the samples generally contain less than 10 per cent uranium-235, and it is believed that in this range, the gross-gamma-counting method is more sensitive, and thus more satisfactory, than the neutron-activation method of analysis. Using these analyses, self-diffusion coefficients for uranium in uranium monocarbide were calculated. The results of these calculations for the two couples examined to date are as follows:

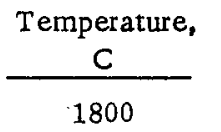

$$
\begin{aligned}
& \text { Self-Diffusion Coefficient, } \\
& \text { D. } \mathrm{cm}^{2} \mathrm{sec} \\
& \sim 3 \times 10^{-9} \\
& \sim 1 \times 10^{-8}
\end{aligned}
$$




$$
F-5 \text { and } F-6
$$

Two other couples were annealed and examined metallographically. The couples appeared to be satisfactorily bonded and anne:aled. One couple was annealed for $240 \mathrm{~min}$ at $1900 \mathrm{C}$, and the other was annealed for $60 \mathrm{~min}$ at $2100 \mathrm{C}$. These couples will be sampled for analysis for uranium-235.

Future work will include the preparation and analysis of additional diffusion couples.

\section{Irradiation Eiffects in UC}

A. E Austin, D. G. Freas, and C. M. Schwartz

The lattice strain and property changes induced in uranium monocarbide by neutron irradiation is presently being studied. Specimens of uranium monocarbide containing both natural and 10 per cent enriched uranium will be studied. The irradiations are to be carried out at low temperatures $(500$ to $600 \mathrm{~F}$ ) and are to include burnups of 0.01 to 0.02 per cent of the uranium for specimens made of natural uranium and burnups of 0.02 to 1.0 per cent of the uranium for specimens containing 10 per cent enriched uranium. A total of about 36 specirnens will be irradiated. The specimens will be about $1 / 2 \mathrm{in.}$ long and $1 / 4 \mathrm{in}$. in diameter, and will be contained in NaK during irradiation to insure proper heat-transfer conditions.

The natural uranium specimens have been prepared by drop casting and have been radiographed to insure soundness. The inspected castings were stress-relief annealed for $\mathrm{l} \mathrm{hr}$ at $1800 \mathrm{C}$. Each casting was cut into three pieces; including two specimens for irradiation and one control specimen. The preirradiation examinations of each specimen will include dimensional, density, and electrical-resistivity measurements and a final X-ray examination. A chemical analysis and a metallographic examination is to be performed on sections of each control specimen. Because of the small size of each irradiation specimen, it has been necessary to design a special electricalresistivity apparatus which will give reliable measurements and which can be remotely operated.

The design and fabrication of the capsules and encapsulation of the specimens is to be completed during March. The capsules will be irradiated in the Battelle Research Reactor. 

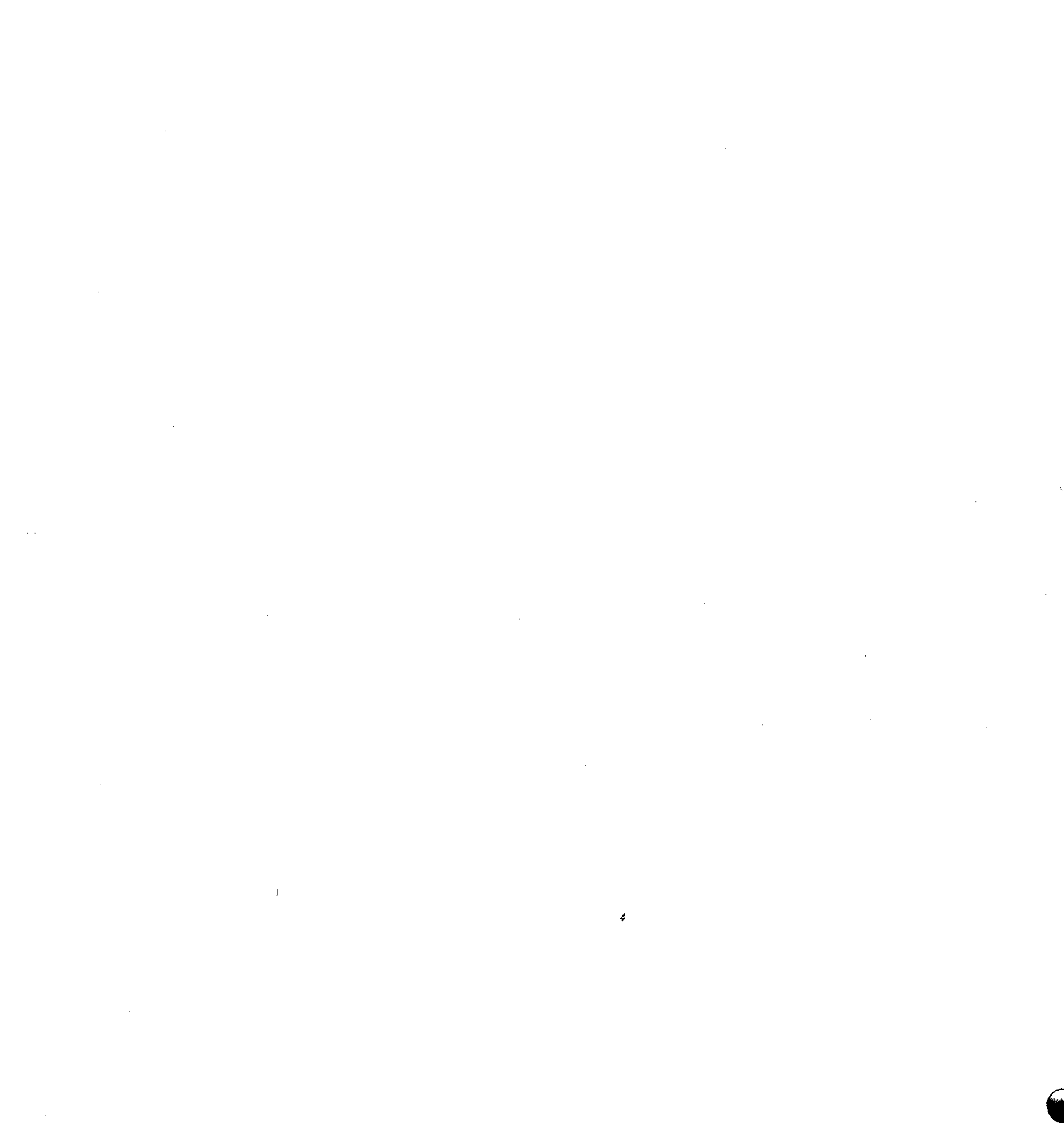


\section{G-1 \\ PHYSICAL RESEARCH (AEC-DR)}

F. A. Rough

In research on methods of preparing high-purity crystals of $\mathrm{UO}_{2}$ suitable for basic studies, some success has been achieved in producing crystals by two methods involving deposition from vapor. Work is also in progress to determine the feasibility of preparing crystals by crystal pulling from a fused bath of $\mathrm{UO}_{2}$ and by zone melting.

Fusion Methods to Prepare Single Crystals of $\mathrm{UO}_{2}$

W. P. Allred and B. Paris

Research on the growth of single crystals of $\mathrm{UO}_{2}$ was continued during February. The major effort during this period was on the growth of crystals by pulling from a molten pool of $\mathrm{UO}_{2}$. A crucible consisting of an alloy of about 90 w/o tungsten, $5 \mathrm{w} / \mathrm{o}$ nickel, and $5 \mathrm{w} / 0$ copper was used to contain the melt. A $20-\mathrm{kw} 450-\mathrm{kc}$ r-f generator was used to heat the crucible. With the generator at full power the $\mathrm{UO}_{2}$ was not completely molten. It was noted that the molten $\mathrm{UO}_{2}$ wet the crucible. This observation is in direct contrast with the lack of wetting observed when pure tungsten is used.

Tantalum shields will be placed around the crucible. This should allow a higher temperature to be reached and thus provide for complete melting of the $\mathrm{UO}_{2}$ samples. Further experiments on crystal pulling will use this arrangement.

A second method for the growing of large single crystals is under investigation. It is planned to zone refine the $\mathrm{UO}_{2}$ in a hor:zontal tungsten tube. The power will be supplied by passing a high current through the tube. The zone will be formed by a tantalum shield which will surround a short section of the tube. The portion of the tungsten under the shield will be the hottest area of the tube. Proper adjustment of the current should melt the $\mathrm{UO}_{2}$ beneath the shield while the remainder of the $\mathrm{UO}_{2}$ ingot remains solid. The shield will then be moved along the ingot, thus producing a moving zone. In addition to the growth of crystals this system will be capable of purifying the $\mathrm{UO}_{2}$ by zone refining. This equipment is being as sembled and will be in operation during March.

\section{Growth of $\mathrm{UO}_{2}$ Crystals From the Vapor Phase}

C. A. Alexander and. R. B. Filbert, Jr.

During the past month the apparatus was modified to prevent the plugging that had been prevalent in earlier runs when using the reaction

$$
\mathrm{UF}_{4}(\mathrm{~g})+2 \mathrm{H}_{2} \mathrm{O}(\mathrm{g}) \rightarrow \mathrm{UO}_{2}(\mathrm{~g})+4 \mathrm{HF}(\mathrm{g})
$$

to produce crystals of $\mathrm{UO}_{2}$. In a $100-\mathrm{hr}$ run, several single crystals ranging in size 
from 6 to $10 \mathrm{~mm}$ in length, as well as a large quantity of small cube-shaped crystals about $1 \mathrm{~mm}^{3}$ in size, were grown from the vapor. Conditions for this run were a charge temperature of $1050 \mathrm{C}$ and a flow rate of $2 \mathrm{~cm}^{3}$ per min of water vapor, over the charge. The amount of water vapor admitted was the stoichiometric amount needed to react with the vapor at a temperature of $1050 \mathrm{C}$.

In addition to the above reaction, runs utilizing the evaporation of KF from a molten-salt solution of $\mathrm{KF}$ and $\mathrm{UO}_{2}$ were made. To date, no crystals larger than $3 \mathrm{~mm}$ have been grown by this process, but the shape of the crystals grown in this manner is more regular than the larger ones grown from the $\mathrm{UF}_{4}-\mathrm{H}_{2} \mathrm{O}$ reaction. For this reason, more runs are being planned utilizing $\mathrm{KF}$ as a solvent for $\mathrm{UO}_{2}$.

One KF run was made in which no appreciable amount of salt was evaporated from the solution. Instead, the temperature was gradually reduced at a rate of about l C per hr. The purpose of this run was to determine if crystalline $\mathrm{UO}_{2}$ could be produced by a reduction in temperature of the solvent alone. Results of this run indicated that evaporation of the solvent salt was much more effective in producing crystals of $\mathrm{UO}_{2}$.

It is planned to continue experiments utilizing the $\mathrm{UF}_{4}-\mathrm{H}_{2} \mathrm{O}$ reaction and evaporation of solvent during the next month in an effort to produce larger single $\mathrm{UO}_{2}$ crystals. 
$\mathrm{H}-1$

\section{RADIOISOTOPES AND RADIATION APPLICATIONS (AEC-OID)}

D. N. Sunderman

Work is continuing on a series of four research programs undertaken for the Office of Isotopes Development. These programs are the development of radioactivetracer quality-control systems, the use of intrinsic radioactive tracers for process control, the study of radiation-induced graft polymerization, and the nitration of hydrocarbons.

The quantitative determination of iron by titration to a radiometric endpoint was found to be very sensitive to the concentration of the tartaric acid complexing agent and the sodium acetate buffer. A mole ratio of additive to iron of 3.6 is necessary in the first case and of at least 40 in the second. The method is accurate if the se conditions are maintained throughout the titration process. The development of a radiometric method for sulfate is under way, and initial results should be available within a month.

Construction of the iron-removal process equipment is under way. Lag time in procuring equipment will allow work to be directed toward further theoretical studies of intrinsic-tracer applications. The two avenues of study are, first, a search for applications similar in chemical process technology to the iron-removal process, and, second, an evaluation of the general applicab:lity of intrinsic tracers to unit operations in process engineering.

A variety of long- and branched-chain e:sters of the methacrylate group was studied to determine the relationship of total radiation dose and free-radical-site formation to ester-group structure. It was found that higher site concentrations were obtained with the more highly branched structures for a given radiation dose. The analysis of gas resulting from irradiation of a sample of radiation-polymerized polymethylmethacrylate indicated the presence of monomer and methyl formate. The formation of monomer has been postulated by other investigators, but its presence has not been demonstrated experimentally in previous work.

The effect of ionizing radiation upon the nitration of hydrocarbons has been better defined by recent experiments. Although considerable difficulty is experienced in reproducing the yields of nitrocyclohexane, it appears certain that radiation effects are of minor importance in this system. Several further experiments with $\mathrm{NO}_{2}$ as the nitrating agent are necessary to fully evaluate this system.

\section{Development of Radioactive-Tracer Quality-Control Systems}

R. Lieberman, C. W. Townley, R. A. Ewing, and

D. N. Sunderman

During February, work was completed on the determination of $\mathrm{Fe}_{2} \mathrm{O}_{3}$ using a complexometric titration with a radiometric endfoint.

The effect of various iron contents on the accuracy of the method as well as the effect of changes in the concentration of the tartaric acid and sodium acetate were 
$\mathrm{H}-2$

investigated. Solutions were titrated with both $0.05 \mathrm{M}$ and $0.02 \mathrm{M}$ EDTA. In all runs, $\mathrm{Y}_{2}{ }^{91}\left(\mathrm{C}_{2} \mathrm{O}_{4}\right)_{3}$ was used as the endpoint indicator. The volume of solution was $50 \mathrm{ml}$.

Using $0.05 \mathrm{M}$ EDTA, it was found that the accuracy of the method decreased when the $\mathrm{Fe}_{2} \mathrm{O}_{3}$ content approached $74 \mathrm{mg}$. The use of $0.02 \mathrm{M}$ EDTA introduced appreciable error in analysis, involving 7 and $15 \mathrm{mg}$ of $\mathrm{Fe}_{2} \mathrm{O}_{3}$.

It was also found that the analysis is dependent upon tartaric acid concentration, and accurate results could not be obtained in runs where the tartaric acid- $\mathrm{Fe}_{2} \mathrm{O}_{3}$ mole ratio differed significantly from 3.6. A large excess of sodium acetate buffer was also . found to be necessary for accurate results. The sodium acetate-Fe $2 \mathrm{O}_{3}$ mole ratio must be at least 40. Satisfactory results could not be obtained with quantities of sodium acetate lower than this. The results of these investigations are summarized in Table $\mathrm{H}-1$.

TABLE H-1. EFFECTS OF REAGENT CONCENTRATIONS ON $\mathrm{Fe}_{2} \mathrm{O}_{3}$ DETERMINATIONS

\begin{tabular}{|c|c|c|c|c|c|c|}
\hline \multirow{2}{*}{$\begin{array}{l}\text { Iron Added } \\
\text { as } \mathrm{Fe}_{2} \mathrm{O}_{3}, \mathrm{mg}\end{array}$} & \multirow{2}{*}{$\begin{array}{l}\text { Molarity } \\
\text { of EDTA } \\
\end{array}$} & \multicolumn{2}{|c|}{ Mole Ratio } & \multirow{2}{*}{$\begin{array}{c}\text { Initial } \\
\mathrm{pH}\end{array}$} & \multirow{2}{*}{$\begin{array}{c}\text { Iron Found } \\
\text { as } \mathrm{Fe}_{2} \mathrm{O}_{3}, \mathrm{mg}\end{array}$} & \multirow{2}{*}{$\begin{array}{c}\text { Absolute } \\
\text { Error, } \\
\text { per cent } \\
\end{array}$} \\
\hline & & Tartaric Acid: $\mathrm{Fe}_{2} \mathrm{O}_{3}$ & Sodium Acetate: $\mathrm{Fe}_{2} \mathrm{O}_{3}$ & & & \\
\hline \multirow[t]{2}{*}{7.36} & 0.0200 & 3.60 & 43.2 & 5.0 & 7.50 & 1.90 \\
\hline & & 3.60 & 43.2 & 5.0 & 7.61 & 3.40 \\
\hline \multirow[t]{5}{*}{14.72} & 0.0200 & 3.60 & 43.2 & 5.0 & 14.72 & 0.00 \\
\hline & & 3.60 & 43.2 & 5.0 & 15.09 & 2.51 \\
\hline & & 3.60 & 43.2 & 5.0 & 15.04 & 2.17 \\
\hline & 0.0499 & 3.60 & 43.2 & 5.0 & 14.52 & -1.36 \\
\hline & & 3.60 & 43.2 & 5.0 & 14.68 & -0.27 \\
\hline \multirow[t]{5}{*}{36.81} & 0.0499 & 3.60 & 64.8 & 5.2 & 37.02 & 0.57 \\
\hline & & 6.06 & 64.8 & 4.9 & $--(a)$ & -- \\
\hline & & 3.60 & 21.6 & 4.6 & $--(a)$ & -- \\
\hline & & 1.80 & 43.2 & 5.2 & $--(a)$ & -- \\
\hline & & 2.02 & 21.6 & 4.7 & $--(a)$ & -- \\
\hline \multirow[t]{4}{*}{73.62} & 0.0499 & 3.60 & 43.4 & 5.0 & 74.13 & 0.69 \\
\hline & & 3.60 & 43.4 & 5.0 & 76.82 & 4.35 \\
\hline & & 2.88 & 35.8 & 5.0 & 67.26 & -8.65 \\
\hline & & 1.94 & 21.6 & 4.8 & $--(a)$ & - \\
\hline
\end{tabular}

(a) Endpoint could not be observed.

Several values presented in the table of results of iron determinations given in last month's report (BMI-1409) were in error. The $\mathrm{Fe}_{2} \mathrm{O}_{3}$ concentrations presented in that table were high by a factor of 2 . The corrected values are presented in Table $\mathrm{H}-2$. These determinations were made with a $50-\mathrm{ml}$ solution volume, a tartaric acid $-\mathrm{Fe}_{2} \mathrm{O}_{3}$ mole ratio of 3.60 , and a sodium acetate $-\mathrm{Fe}_{2} \mathrm{O}_{3}$ mole ratio of 43.2 . The best results were obtained under these conditions. The $\mathrm{Fe}_{2} \mathrm{O}_{3}$ concentration recommended for optimum accuracy is 20 to $40 \mathrm{mg}$ of $\mathrm{Fe}_{2} \mathrm{O}_{3}$ per $50 \mathrm{ml}$.

Work has begun on a radiometric method for the determination of sulfate in portland cement. Strontium -89 will be used to precipitate $\mathrm{Sr}^{89} \mathrm{SO} 4$. The observed change in radioactivity of the sample as the result of precipitation will be used to determine the sulfate content. It is expected that this method will be applicable directly to cement samples, with no prior separations necessary. 
H-3

TABLE H-2, PRECISION AND ACCURACT OF EIGHT Fe22 $\mathrm{O}_{3}$ DETERMINATIONS

(Iron added, expressed as $\mathrm{Fe}_{2} \mathrm{O}_{3}=37.12 \mathrm{mg}$.)

\begin{tabular}{cccc}
\hline \hline Determination & $\begin{array}{c}\mathrm{Fe}_{2} \mathrm{O}_{3} \\
\text { mg }\end{array}$ & $\begin{array}{c}\text { Deviation } \\
\text { From Average, mg }\end{array}$ & $\begin{array}{c}\text { Absolute Error, } \\
\text { per cent }\end{array}$ \\
\hline & 36.82 & -0.40 & 0.81 \\
2 & 37.14 & -0.08 & 0.05 \\
3 & 37.29 & +0.07 & 0.46 \\
4 & 37.22 & 0.00 & 0.27 \\
5 & 37.33 & +0.11 & 0.57 \\
6 & 37.81 & +0.59 & 1.86 \\
7 & 37.17 & -0.05 & 0.13 \\
8 & 37.02 & -0.20 & 0.27 \\
Average values & 37.22 & \pm 0.18 & -- \\
Standard deviation & -- & \pm 0.29 & -- \\
& & & \\
\hline
\end{tabular}

An investigation of other industries in which radioisotopes might be applied to quality control has begun. This investigation will continue in order to select an industry for study when work has been completed with the cement industry. The final choice will be made after consultation with the Office of Isotopes Development.

\section{Use of Intrinsic Radioactive Tracers for Process Control}

J. L. McFarling, P. Gluck, J. F. Kircher, and D. N. Sunderman

During February, work has continued on the construction of the model ironremoval process system. Several of the equipment items are ready for installation; however, delays in delivery of other items have slowed construction. These delays are not expected to be long or to seriously affect the experimental program as planned. Construction will be accelerated during the coming month. In the meantime, emphasis has been shifted to the theoretical phases of the program. Attention has been directed toward other applications of radiotracer-controlled iron removal similar to the ammonia-leach nickel-refining process. This phase of the program is being broadened by surveying the general field of hydrometallurgy in an attempt to uncover potential intrinsic radiotracer applications in addition to iron removal. The present approach is to investigate the use of any applicable intrinsic radiotracer to facilitate the removal of critical impurities in various hydrometallurgical processes. It is felt that the radiotracer techniques developed during the present engineering study of iron removal will be directly applicable to the majority of potential applications uncovered in the investigative survey.

The study of chemical engineering unit operations to determine general conditions for application of intrinsic radiotracers is just beginning. This phase of the program will receive increased emphasis during the coming month.

Future work will be concerned with completion of the model process as quickly as possible and continuation of the theoretical studies. 
$\mathrm{H}-4$

\section{Graft-Polymerization Studies}

I. S. Ungar, W. B. Gager, J. F. Kircher, and R. I. Leininger

During February the investigation of the mechanism of formation and decay of radiation-induced free radicals continued. A study of the effect of total dose on site formation was made for polypropylmethacrylate (PPMA), polyisopropylmethacrylate (PisoPMA), polyisobutylmethacrylate (PisoBMA), and poly-secondary-butylmethacrylate (PsecBMA). Sites per monomer unit versus total dose were plotted for each of the samples. The results from PisoBMA and PsecBMA were compared with those previously found for polybutylmethacrylate (PBMA) and poly-tertiary-butylmethacrylate (PtertBMA). It was found that at a given dose the site concentration forms a series where PtertBMA > PsecBMA > PisoBMA > PBMA. In other words the greater the branching of the ester chain, the greater the site concentration for a given dose. It was also found that the less highly branched esters reached their maximum site concentration at lower doses, and the concentration decreased sooner with increasing dose. Similar results were obtained for PPMA and PisoPMA. The PPMA had fewer sites at a given dose than $\mathrm{Pi}$ soPMA, and reached its maximum site concentration at a lower dose.

During this month, a sample of radiation-polymerized polymethylmethacrylate (PMMA) was irradiated to approximately $4 \times 107$ rads, and the vapors produced were analyzed by gas chromatography. Two esters, methylmethacrylate and methyl formate, were identified. The presence of monomer is significant since its presence has often been postulated but not proven. Methyl formate, which has previously been reported, was found in 25 times the concentration of methylmethacrylate. It thus becomes apparent that the action of gamma irradiation is not limited to chain scission. The presence of methyl formate and a two-order-of-magnitude increase in site concentration between PBMA and PtertBMA indicates that the ester group is attacked and that the nature of the ester group may determine to a large extent the ease with which sites are formed.

During the next month work will continue to determine the mechanism of radical formation in methacrylates. The vapors from irradiated PMBA's will be analyzed. An attempt will be made to correlate the products of irradiation with the number of sites formed and the shape of the EPR spectrum.

Information has been received that a short paper based on this work has been accepted for presentation at the Gordon Conference on Radiation Chemistry this summer.

\section{Nitration of Hydrocarbons}

M. J. Oestmann, G. A. Lutz, E. J. Kahler, and J. F. Kircher

During February, the effect of radiation on the nitric acid-cyclohexane system was investigated under conditions of more efficient mixing of the reactants. Seven irradiation and thermal experiments were completed. Analytical results are reported in Table $\mathrm{H}-3$. 
TABLE H-3. PRODUCT ANALYSES OF NITRIC ACID-CYCLOHEXANE EXPERIMENTS(a)

\begin{tabular}{|c|c|c|c|c|c|c|c|c|c|c|}
\hline \multirow[b]{2}{*}{ Experiment } & \multirow[b]{2}{*}{$\begin{array}{c}\text { Temperature, } \\
\mathrm{C} \\
\end{array}$} & \multirow[b]{2}{*}{$\begin{array}{c}\text { Time, } \\
\mathrm{hr}\end{array}$} & \multirow[b]{2}{*}{$\begin{array}{c}\text { Gamma Dose, } \\
10^{6} \mathrm{rads}\end{array}$} & \multirow[b]{2}{*}{$\begin{array}{l}\text { Moles } \\
\text { of Gas } \\
\text { Produced }\end{array}$} & \multicolumn{6}{|c|}{ Analysis of Recovered Organic Solution, w/o } \\
\hline & & & & & $\mathrm{C}_{6} \mathrm{H}_{11} \mathrm{NO}_{2}$ & $\left(\mathrm{C}_{6} \mathrm{H}_{11}\right)_{\mathrm{m}}\left(\mathrm{NO}_{2}\right)_{\mathrm{n}}$ & $\left(\mathrm{C}_{6} \mathrm{H}_{11}\right)_{2}$ & $\mathrm{C}_{6} \mathrm{H}_{11} \mathrm{OH}$ & $\mathrm{C}_{5} \mathrm{H}_{10} \mathrm{C}=\mathrm{O}$ & $\begin{array}{l}\text { Adipic Acld } \\
\text { or Other } \\
\text { Solids } \\
\end{array}$ \\
\hline 56 & 60 & 20 & 3.8 & 0.007 & 0.75 & -- & -- & Trace & Trace & 0.54 \\
\hline 57 & 60 & 45 & -- & 0.014 & 1.4 & 0.06 & 0.08 & 0.09 & 0.02 & 2.20 \\
\hline $54(\mathrm{~b})$ & 60 & 45 & 8.6 & 0.018 & 4.5 & 0.21 & 0.11 & 0.20 & 0.04 & 1.92 \\
\hline $55^{(b)}$ & 60 & 45 & -- & 0.017 & 3.3 & Trace & Trace & 0.06 & Trace & 1.81 \\
\hline 59 & 60 & 65 & 12.4 & 0.018 & 1.1 & 0.14 & 0.44 & 0.25 & 0.13 & 1.95 \\
\hline 53 & 60 & 65 & -- & 0.019 & 1.6 & -- & -- & 0.13 & 0.02 & 0.96 \\
\hline 58 & 110 & 20 & -- & 0.029 & 3.9 & -- & 0.23 & 0.18 & 0.04 & 1.11 \\
\hline 46 & 60 & 45 & 8.6 & 0.020 & 1.4 & 0.12 & 0.05 & 0.17 & 0.02 & 1.67 \\
\hline
\end{tabular}

(a) All experiments were conducted in glass vessels using a 10/1 mole ratio of cyclohexane/nitric acid.

(b) Reaction mixture consisting of nitric acid and cyclohexane spiked with $1.4 \mathrm{w} / 0 \mathrm{C}_{6} \mathrm{H}_{11} \mathrm{NO}_{2}$. 
$\mathrm{H}-6$

A $10 / 1$ mole ratio of cyclohexane/nitric acid was used in all experiments. The glass reaction vessels used were designed to keep the magnetic stirring bar centered. Good stirring was assured in these experiments. All experiments except 58 were conducted at $60 \mathrm{C}$ for periods of 20 to $65 \mathrm{hr}$. The corresponding gamma doses were from $3.8 \times 10^{6}$ to $1.2 \times 10^{7} \mathrm{rads}$.

Table H-3 shows the approximate moles of gas produced during each reaction. Gas samples from Experiments 56, 59, and 58 were analyzed by mass spectrometry. The major component was nitrous oxide, amounting to about 55 volume per cent. From proposed reaction mechanisms*, this is the expected result. Smaller yields of nitrogen, nitric oxide, carbon dioxide and monoxide, and hydrogen were obtained. Less than 1 volume per cent each of argon, methane, oxygen, and water was obtained.

The distribution of product yields was about the same in each experiment: There was, however, a slight increase in the yield of oxidized products obtained with an increase in reaction temperature from $60 \mathrm{C}$ (Experiment 56) to $110 \mathrm{C}$ (Experiment 58).

To confirm the results obtained previously on the radiation stability of nitrocyclohexane, Experiments 54 and 55 were conducted for $45 \mathrm{hr}$ using cyclohexane spiked with $1.4 \mathrm{w} /$ o nitrocyclohexane prior to reaction. Approximately the same yields were obtained in the spiked reactions as in the unspiked reactions (Experiments 46 and 57). Therefore, no significant degradation of nitrocyclohexane occurred during radiation or heating.

The accumulated data show poor reproducibility in product yields from either irradiation or nonirradiation experiments. In comparing irradiation and thermal experiments, the range of nitrocyclohexane yields overlaps even for experiments with different exposure times. This may be due to difficulty in obtaining identical experimental conditions and errors in the analytical procedure. Consequently, no definite conclusion as to the effect of radiation on nitration can be drawn. It appears, however, that radiation does not produce large effects on nitration under the particular experimental conditions used.

Five experiments using $\mathrm{NO}_{2}$ as the nitrating agent were completed. Reactions were conducted at $60 \mathrm{C}$ with a $10 / 1$ mole ratio of cyclohexane/nitrogen dioxide. Results of the se experiments will be reported as soon as they become available. Next month additional $\mathrm{NO}_{2}$ experiments will be continued.

*Topchiev, A. V., Nitration of Hydrocarbons, Pergamon Press, New York (1959), pp 167-168. 


\section{VOID-DISTRIBUTION A.ND HEAT-TRANSFER STUDIES (AEC-EURATOM)}

D. V. Grillot, R. O. Wooton, M. F. Peter, H. M. Epstein, and J. W. Chastain

During February experimental measurements of voids resulting from subcooled boiling continued. The ranges of parameters used in the tests were the following:

$$
\text { Pressure } \quad 600 \text { to } 1200 \mathrm{psia}
$$

Reynolds number Up to 52,500

$$
\text { Heat flux D. } 2 \times 10^{5} \text { to } 2.0 \times 10^{5} \mathrm{Btu} /(\mathrm{hr})\left(\mathrm{ft}^{2}\right)
$$

The over-all stability of the tests has improved greatly, but the effects of longterm drifts are still noticeable. However, the drifting is slow enough so that its effect on relative measurements is nearly negligible.

A specially designed chamber with a high beta-to-gamma sensitivity ratio is being aged at present and should be ready for trial operation next month. This system should give better statistical data in a given time period than the Geiger counter now in use. 
$\theta$

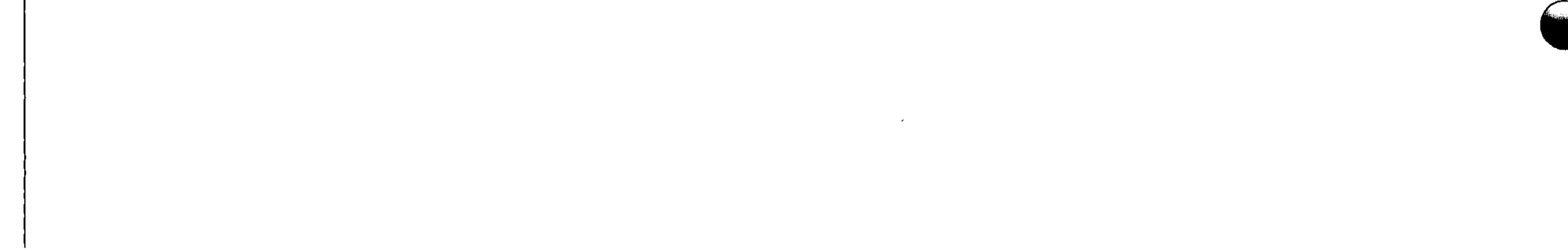

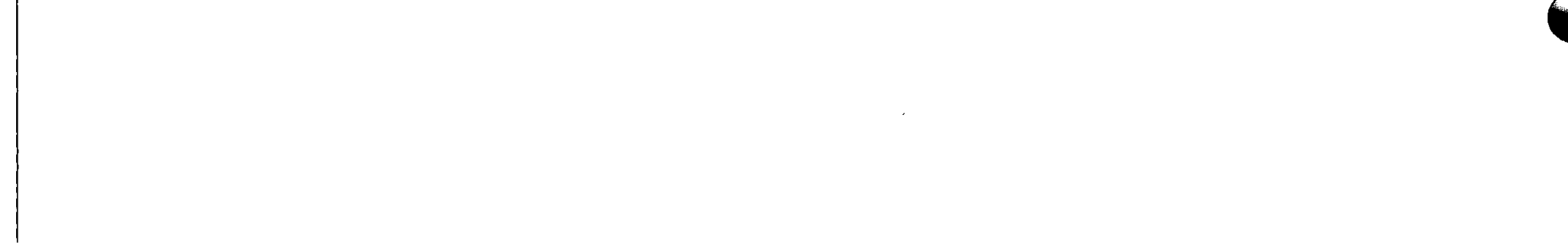

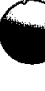


$J-1$

MATERIALS DEVELOPMENT' AND EVALUATION (HAPO)

F. R. Shober

The creep properties of annealed and of 15 per cent cold-worked Zircaloy-2 are being investigated under a number of conditions of stress and temperature. Studies to develop a AgBr fuel-element leak detector for use in water-cooled reactors have been concluded.

Experimental work on the development of a thermal-neutron-flux monitor is being discontinued. In a program to develop corrosion-resistant welding alloys for use with Hastelloy F, 12 new alloys have been selected. The selection was based on the corrosion and metallurgical evaluation of the first series of alloys. Melting and fabrication will be initiated in March.

\section{Mechanical Properties of Zirconium Alloys}

L. P. Rice and J. A. VanEcho

This program is concerned with determining creep properties of Zircaloy-2 sheet material under various conditions of stress and temperature. Such information is necessary in the design of pressurized process tubes, the Plutonium Recycle Program, and other applications at Hanford utilizing the Zircaloy-2 alloy.

The program consists essentially of three phases. Phase I is concerned with investigating stress-rupture, long-time creep, conditions of time and deformation for onset of third-stage creep, and the effect of time and stress on the ductility of 15 per cent cold-worked material. Temperatures of interest are 550, 650, and $750 \mathrm{~F}$.

Stresses range from those causing rupture in a few hours to very low stresses resulting in creep rates of about 0.000001 per cent per hr. Tests may run for as long as 15,000 to $20,000 \mathrm{hr}$ in obtaining such low creep rates. In this and the other phases of the present program, all tests are made in vaculum of the order of 0.001 to $0.0001 \mathrm{~mm}$ of mercury.

Phase II is concerned with the effect of temperature cycling on creep properties and ductility of annealed and of 15 per cent cold-worked Zircaloy-2 sheet. Temperatures of interest here are 550 and $650 \mathrm{~F}$. The cycle consists of 6 days at temperature and 1 day at room temperature with the specimer continuously under stress. Times involved are $3000 \mathrm{hr}$ per test at temperature or $3500 \mathrm{hr}$ of total time. The stresses chosen result in creep rates of about 0.000005 to 0.0005 per cent per hr.

This phase of the program has just lately been expanded to include determining the effect of stress as well as temperature cycling on the creep properties and ductility of annealed Zircaloy-2. Both stress and temperature are being cycled 1 day out of 7 with the stress reduced to zero and the temperature lowered to room temperature. Otherwise, the procedure is similar to that of the temperature-cycled tests. 
Phase III of the program is much the same as Phase I but involves annealed rather than cold-worked material. Conditions of interest include temperatures of 550, 650, and $750 \mathrm{~F}$ and stresses that will result in rupture as well as creep rates as low as 0.000001 per cent per hr. Maximum test times are expected to be in the vicinity of $10,000 \mathrm{hr}$.

Thermal-Neutron-Flux Monitoring System

D. R. Grieser, P. M. Steinback, J. W. Lennon, and W. H. Goldthwaite

The objective of this program is the development of a power-balancing-type thermal-neutron flux monitor.

The program has concentrated on the development of small, reliable, and stable uranium-bearing elements required for insertion into the flux probe. An examination of the experimental evidence garnered from systematic fabrication and electricalproperty studies of $\mathrm{MoSi}_{2}-\mathrm{Al}_{2} \mathrm{O}_{3}-\mathrm{UO}_{2}$ ceramic elements strongly suggests that suitable probe elements cannot be produced with this specific combination.

Experimental work has been suspended, and a topical report is being written. Concurrently, a number of alternate materials combinations and approaches are being evaluated for possible use in the development of a power-balancing device.

\section{Development of Corrosion-Resistant Welding Alloys for Use With Hastelloy $F$ to Contain Decladding Solutions}

C. L. Peterson, P. D. Miller, J. D. Jackson, A. M. Hall, R. E. Monroe, and W. K. Boyd

Based on the corrosion and metallurgical evaluations of the first 12 experimental alloys, a second list of 12 experimental alloys to be melted at BMI was agreed upon during a conference at HAPO. This list is tentative, in that some of the proposed alloys may not be amenable to forging and rolling. The melting program will be carried out during March. The emphasis on the new list of alloys has been changed to considering the se alloys, themselves, as possible container materials and not as welding alloys for vacuum-melted Hastelloy F. Consequently, only self-welded coupons of these alloys will be employed in the subsequent corrosion evaluations in boiling Sulfex and Niflex solutions. 
K. -1

DEVELOPMENTS FOR ALUMINUM-CLAD FUEL ELEMENTS (SRL)

R. J. Carlson and N. E. Daniel

Stress-rupture tests at $200 \mathrm{C}$ using stresses of 7,000 to $11,000 \mathrm{psi}$ have been conducted on an aluminum- $35 \mathrm{w} / \mathrm{o}$ uranium binary alloy and on an aluminum $-35 \mathrm{w} / \mathrm{o}$ uranium alloy containing 2 and $3 \mathrm{w} / 0$ tin or zirconium. The time to failure under the se variable conditions has been from lesis than $1 \mathrm{hr}$ to more than $200 \mathrm{hr}$.

Differential-thermal-analysis data incicate the tenary eutectic temperature for the aluminum-uranium-nickel alloy is $621 \mathrm{C}$. From the se data and data obtained from binary alloys of the elements, it is believed that either iron or silicon is effective in depressing the eutectic temperature when nickel is present.

\section{Preparation of Aluminum-Uranium Alloys}

N. E. Daniel, E. L. Foster, and R. F. Dickerson

Aluminum-uranium alloys containing concentrations of uranium in excess of 20 w/o are of interest as reactor fuels if satisfactory casting and fabricating techniques can be developed. The final product sought is a fuel element in the form of a hollow cylindrical tube clad inside and outside with aluminum. Improvements in both the casting and fabricating characteristics of aluminum-35 w/o uranium alloys have been observed when suitable ternary additions are made to the alloy. The improved casting characteristics are attributed to the increased fluidity imparted to the alloys by the additions, and to the smaller compound particle size exhibited by the alloys containing these additions. The improvements in fabricating characteristics are attributed to the inhibition of the $\mathrm{UAl}_{3}$-to-UAl 4 reaction. Two additions which are capable of complete retention of $\mathrm{UAl}_{3}$ under normal casting conditions are tin and zirconium. The program in progress is concerned with the effects of up to $3.0 \mathrm{w} / 0$ tin and zirconium on the castability, the corrosion resistance, and the mechanical properties of the aluminum$35 \mathrm{w} / \mathrm{o}$ uranium alloy.

Hot-hardness and elevated-temperature tensile tests have been completed, and the data from these tests have been used to determine the stresses and temperatures of subsequent creep and stress-rupture tests. It was decided that stress-rupture data should be obtained at $200 \mathrm{C}$, with the initial stress approximating the ultimate strength of the alloys. The results of the stress-rupture tests conducted under these conditions were reported in the previous report. Recently, tests have been conducted using reduced stresses at $200 \mathrm{C}$. The results from these tests are given in the tabulation below. 
$\mathrm{K}-2$

\begin{tabular}{|c|c|c|c|c|}
\hline Alloy Composition & $\begin{array}{l}\text { Stress, } \\
\text { psi }\end{array}$ & $\begin{array}{l}\text { Time to } \\
\text { Failure, hr }\end{array}$ & $\begin{array}{l}\text { Elongation, } \\
\text { per cent }\end{array}$ & $\begin{array}{c}\text { Reduction in Area, } \\
\text { per cent }\end{array}$ \\
\hline \multirow{2}{*}{$\mathrm{Al}-35 \mathrm{w} / \mathrm{o} \mathrm{U}-2.0 \mathrm{w} / \mathrm{o} \mathrm{Sn}$} & 11,000 & 0.9 & 19.5 & 23.0 \\
\hline & 8,500 & 57 & 9.8 & 14.4 \\
\hline \multirow[t]{2}{*}{$\mathrm{A} 1-35 \mathrm{w} / \mathrm{O} \mathrm{U}-3.0 \mathrm{w} / \mathrm{o} \mathrm{Sn}$} & 10,000 & 1.4 & 17.9 & 24 \\
\hline & 7,000 & 130 & 11.4 & 18 \\
\hline \multirow[t]{2}{*}{$\mathrm{Al}-35 \mathrm{w} / \mathrm{OU}$} & 11,000 & 6 & 8.9 & 15.8 \\
\hline & 9,500 & 227 & 8.9 & 14.3 \\
\hline \multirow{4}{*}{$\mathrm{A} 1-35 \mathrm{w} / \mathrm{o} \mathrm{U}-2.0 \mathrm{w} / \mathrm{o} \mathrm{Zr}$} & 11,000 & 4.7 & 14.6 & 22.3 \\
\hline & 11,000 & 3 & 20.3 & 24.7 \\
\hline & 9,000 & 57 & 18.7 & 21.7 \\
\hline & 9,000 & 92.5 & 17.1 & 24.2 \\
\hline \multirow[t]{3}{*}{$\mathrm{Al}-35 \mathrm{w} / \mathrm{o} \mathrm{U}-3.0 \mathrm{w} / \mathrm{o} \mathrm{Zr}$} & 11,000 & 3.2 & 15.4 & 22.9 \\
\hline & 10,000 & 6.3 & 18.7 & 28.9 \\
\hline & 8,500 & 48 & 13.8 & 7.9 \\
\hline
\end{tabular}

With the data available from the stress-rupture tests it is now possible to initiate creep testing. It is planned to conduct these tests at $200 \mathrm{C}$ also for periods up to $1000 \mathrm{hr}$. The effects of two or more elemental additions on the structure of the aluminum-35 w/o uranium alloy is to be evaluated by metallographic examination of 1-in. -diameter by 8-in. -long castings.

\section{A Study of the Aluminum-Uranium-Nickel Eutectic Temperature}

V. W. Storhok, A. A. Bauer, and R. F. Dickerson

A program is being conducted to determine the ternary eutectic temperature in an aluminum-13 w/o uranium-5. 6 w/o nickel alloy prepared from commercial materials. Previously, a ternary eutectic temperature of $624 \pm 2 \mathrm{C}$ was observed for a similar alloy prepared with high-purity components.

Alloys have been prepared for study by induction melting in a zirconia crucible and casting into copper molds. Spectrographic analysis of the aluminum employed in the alloy indicated impurities to be $0.36 \mathrm{w} / 0$ iron, $0.07 \mathrm{w} / 0$ silicon, $0.01 \mathrm{w} / 0$ copper, and $0.006 \mathrm{w} / 0$ manganese. The nickel contained $0.1 \mathrm{w} / 0$ cobalt, $0.01 \mathrm{w} / 0$ silicon, $0.001 \mathrm{w} / 0$ copper, and less than $0.003 \mathrm{w} / \mathrm{o}$ manganese. The uranium was commercial grade.

Differential thermal-analysis data indicate the ternary eutectic temperature for an alloy prepared with this material is $621 \mathrm{C}$. Very close temperature agreement was observed on all analytic runs for this alloy. In addition, the aluminum-13.1 w/o uranium and aluminum-5.7 w/o nickel binary eutectic alloys exhibited eutectic temperatures of 640 and $629 \mathrm{C}$, respectively. In alloys prepared from pure materials, both the se temperatures are $640 \mathrm{C}$. From these data, it would appear that the eutecticdepressing impurity is effective only when nickel is present. It appears probable that either iron or silicon is the impurity responsible for the lowered melting point.

Additional thermal data are being obtained by a comparative differential technique to verify the temperature differences observed. 


\title{
L- 1 and L-2
}

\section{REFLECTIVE-INSULATION STUDIES (KAISER)}

\author{
L. J. Flanigan and H. R. Hazard
}

Studies of reflective-insulation materials suitable for use in the Experimental Gas-Cooled Reactor are being conducted. Suitability of the insulation will be judged by its freedom from distortion or other damage occurring during thermal cycling and rapid decompression and by its insulating value. Previously reported work includes completion of the conceptual design of the heat-transfer apparatus, the decompression chamber, and the thermal-cycling equipment and initiation of the detailed designs.

In February, detailed design of the thermal-cycling equipment was completed and construction started. The heat-transfer apparatus design is about 80 per cent complete, and construction of components has been started. The vessel to be used for decompression studies has been designed, and construction drawings are being prepared.

In March construction of the thermal-cycling equipment will be completed, and the decompression chamber will be built. Design of the heat-transfer apparatus will be finished and fab.ication continued. 


\title{
PROBLEMS ASSOCIATED WITH THE RECOVERY OF SPENT REACTOR FUEL ELEMENTS (ORNL)
}

\section{Corrosion Studies of the Fluoride-Volatility Process}

\author{
P. D. Miller, C. L. Peterson, W. N. Stiegelmeyer, and F. W. Fink
}

Sections from a titanium steam coil, part of which failed during service in an ORNL Purex acid-recovery evaporator, were examined. A metallographic study showed no significant structural differences which could account for the fracture. It has been concluded that failure was the result of a mechanical rubbing action by a vertical tube in the assembly.

\section{Study of the Effects of Irradiation on Cladding-} and Core-Dissolution Processes

R. A. Ewing, H. B. Brugger, and D. N. Sunderman

\section{Sulfex Process}

Analyses of the dissolutions of the ORR-irradiated Consolidated Edison powerreactor prototype pins have been completed. Results of these studies are contained in a topical report in preparation.

Preliminary Sulfex dissolution experiments of a new batch of "cold" Consolidated Edison prototype pins, of composition more nearly approaching design specifications, have begun. These experiments are to provide reference data for the subsequent dissolution studies of MTR-irradiated high-density fuel pins. Dissolution tests of the irradiated pins can begin as soon as the se are released from their present postirradiation studies.

\section{Darex Process}

No Darex dissolutions were conducted during the month. 


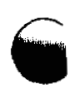

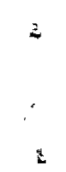

$\theta$ 
$\mathrm{N}-1$ and $\mathrm{N}-2$

VARIABLE-MODERATOR REACTOR CRITICAL-ASSEMBLY STUDIES (ATL-A)

R. A. Egen, L. H. Bettenhausen, W. S. Hogan, D. A. Dingee, and J. W. Chastain

Preparation for the VMR critical-assembly studies continued. The major core components arrived from Advanced Technology Laboratories (American-Standard) and were assembled. The liquid-handling systems were completed, and the control apparatus was nearly all installed.

The first shipment of fuel pins was received. A fuel element was partially assembled to determine future assembly procedures.

A final review of the experimental program was made with ATL personnel, and the tests were sequentially arranged in accordance with their plans for use of the data.

The remainder of the fuel is expected in March. Initial criticality experiments will follow shortly after receipt of the fuel. 


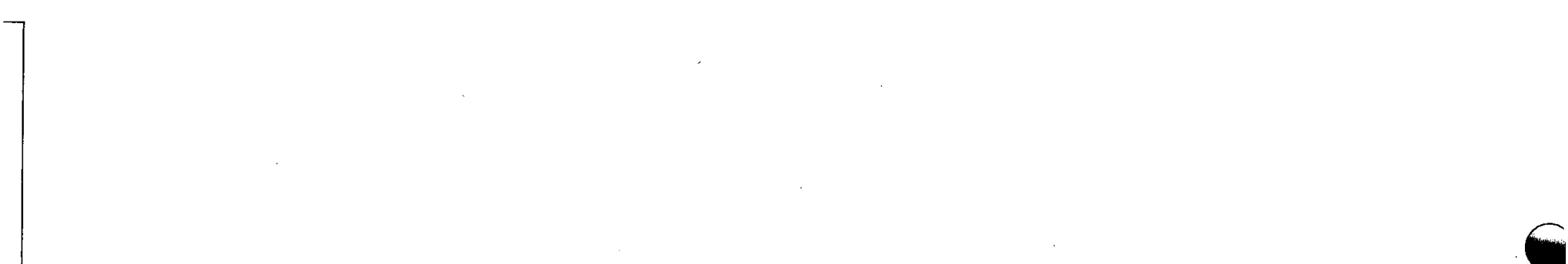

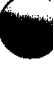

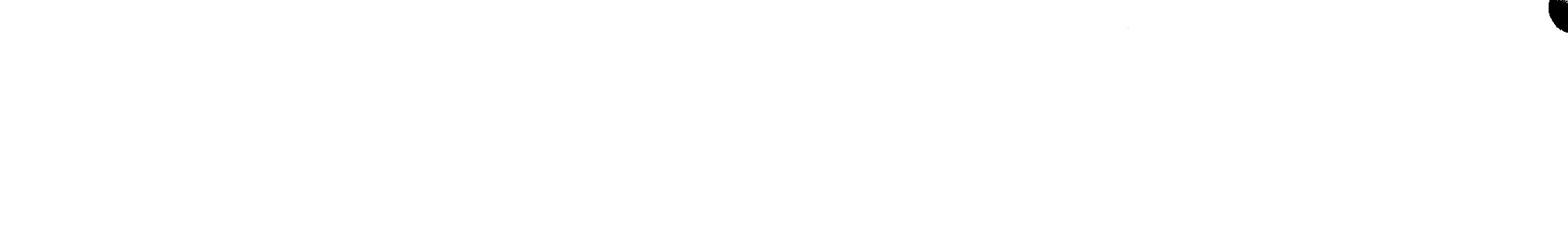

.<smiles>[IH2]</smiles> 
O-1

URANIUM CARBIDE AS A REACTOR FUEL (AI)

F. A. Rough

The examination of a capsule of specimens containing nominal $4.8 \mathrm{w} / \mathrm{o}$ carbon irradiated to about a $5000-\mathrm{MWD} / \mathrm{T}$ uranium kurnup has been completed. The results are comparable with those for $4.6 \mathrm{w} / 0$ carbon and $5.0 \mathrm{w} / 0$ carbon specimens having similar burnups. Some cracking and only minor dimensional density changes were observed.

One additional capsule of specimens is being irradiated to an estimated uranium burnup of $20,000 \mathrm{MWD} / \mathrm{T} \mathrm{U}$.

\section{Irradiation of Urarium Monocarbide}

D. Stahl, J. H. Stang, and W. H. Goldthwaite

During February, specimen center-line temperatures for Capsule BMI-23-4, which contains uranium monocarbide specimens, were in the 1050 to $1100 \mathrm{~F}$ range. The capsule is scheduled for discharge from the MTR at the end of Cycle 140 (mid-June, 1960) for a total irradiation of $26 \mathrm{MTR}$ cycles and a target burnup of $20,000 \mathrm{MWD} / \mathrm{T}$ of uranium. This capsule is the final one of this series.

\section{Postirradiation Examination of Uranium Monocarbide}

S. Alfant, A. W. Hare, F. A. Rough, and R. F. Dickerson

The primary objective of this program is to investigate the effects of neutron irradiation and fission-product damage on uranium monocarbide, and to evaluate this material as a possible fuel for sodium-cooled reactors.

As reported previously, the postir radiation examination of specimens from Capsules BMI-23-3 and BMI-23-5 has been completed. It was found that the uranium$5.0 \mathrm{w} / 0$ carbon specimens in BMI-23-3 and the uranium-4. $6 \mathrm{w} / 0$ carbon specimens in BMI-23-5, after being irradiated to nominal uranium burnups of $10,000 \mathrm{MWD} / \mathrm{T}$ and $5000 \mathrm{MWD} / \mathrm{T}$, respectively, did not suffer any serious irradiation damage. However, the microscopic examination of the $5.0 \mathrm{w} / 0$ carbon specimens revealed a general depletion of the $\mathrm{UC}_{2}$ structure, due possibly to neutron irradiation, or to a thermal gradient during irradiation.

Examination of Capsule BMI-23-6 was initiated at the BMI Hot-Cell Facility. This capsule, containing specimens with nominal compositions of uranium-4. 8 w/o carbon, was irradiated six MTR cycles to estimated burnups of approximately 0.69 a/o uranium or $5100 \mathrm{MWD} / \mathrm{T}$ of uranium and $0.72 \mathrm{a} / \mathrm{o}$ uranium or $5400 \mathrm{MWD} / \mathrm{T}$ of uranium for the top and bottom 2-in. specimens, respectively. 
Upon arrival at the Hot-Cell Facility, the outside dosimeter wires were removed, the capsule was punctured, and the released fission gas was collected in small glass vials for subsequent analyses. Macroexamination of the specimens revealed very little evidence of radiation damage. The specimens generally were in good condition, but contained a few cracks. Some of the $\mathrm{NaK}$ had remained in cracks in the surface areas of the specimens. In areas where the $\mathrm{NaK}$ had not been completely removed from the cracks, it appeared that the $\mathrm{NaK}$ was reacting in air, causing flaking and gradual widening of these cracks.

Microexamination of these specimens revealed some evidences of radial cracking, but less cracking than was observed in the specimens of higher carbon content from the BMI-23-1, BMI-23-2, BMI-23-3, and BMI-23-5 Capsules. A comparison of the postirradiation structures with the preirradiation structures of the same specimens showed no appreciable differences in grain size. The irradiated structures appeared to be completely normal, and typical of structures of the uranium-4. $8 \mathrm{w} / 0$ carbon alloy.

Tables $\mathrm{O}-1$ and $\mathrm{O}-2$ list the pre- and postirradiation measurements of dimensions and density for Capsule BMI-23-6.

T ABLE O-1. DENSITY OF URANIUM -4.8 w/O CARBON SPECIMENS IN CAPSULE BMI-23-6 BEFORE AND AFTER IRRADIATION

\begin{tabular}{lccc}
\hline Specimen & Specimen Density, g per cm ${ }^{3}$ & $\begin{array}{c}\text { Density } \\
\text { Change, } \\
\text { per cent }\end{array}$ \\
\cline { 2 - 3 } AI -41 (top) & Preirradiation & 13.380 & -1.15 \\
AI-46 (bottom) & 13.536 & 13.640 & -1.57 \\
\hline
\end{tabular}

TABLE 0-2. DIAMETER ME ASUREMENTS OF URANIUM -4. 8 w/o CARBON SPECIMENS IN CAPSULE BMI-23-6 BEFORE AND AFTER IRRADIATION

\begin{tabular}{|c|c|c|c|c|c|c|c|}
\hline \multirow[b]{3}{*}{ Specimen } & \multicolumn{6}{|c|}{ Specimen Diameter, in. } & \multirow{3}{*}{$\begin{array}{l}\text { Diameter } \\
\text { Change, } \\
\text { per cent }\end{array}$} \\
\hline & \multirow{2}{*}{$\begin{array}{c}\text { Before } \\
\text { Irradiation }\end{array}$} & \multicolumn{5}{|c|}{ After Irradiation } & \\
\hline & & Reading 1 & Reading 2 & Reading 3 & Reading 4 & Average & \\
\hline AI-41 (top) & 0.3738 & 0.3756 & 0.3759 & 0.3751 & 0.3755 & 0.3756 & +0.5 \\
\hline AI -46 (bottom) & 0.3758 & 0.3779 & 0.3774 & 0.3775 & 0.3779 & 0.3777 & +0.5 \\
\hline
\end{tabular}




$$
0-3 \text { and } 0-4
$$

An examination of the above data indicates that the uranium-3. $8 \mathrm{w} / \mathrm{o}$ carbon (stoichiometric) specimens behaved very well at the average surface and core temperatures shown in Table O-3.

TABLE 0-3. AVERAGE SURFACE AND CORI: TEMPERATURES OF URANIUM-4. $8 \mathrm{w} / \mathrm{O}$ CARBON SPECIMENS IN CAPSIJLE BMI-23-6

\begin{tabular}{lcc}
\hline & & Temperature, $\mathrm{F}$ \\
Specimen & Surface & Core \\
\hline AI-41 (top) & 900 & 1370 \\
AI-46 (bottom) & 565 & 900 \\
\hline
\end{tabular}

The relatively small changes in density and diameter indicate negligible effects of irradiation on the dimensional stability of UC at this composition.

Burnup data based on radiochemical analyses and dosimetry will be forthcoming in the near future. 
-

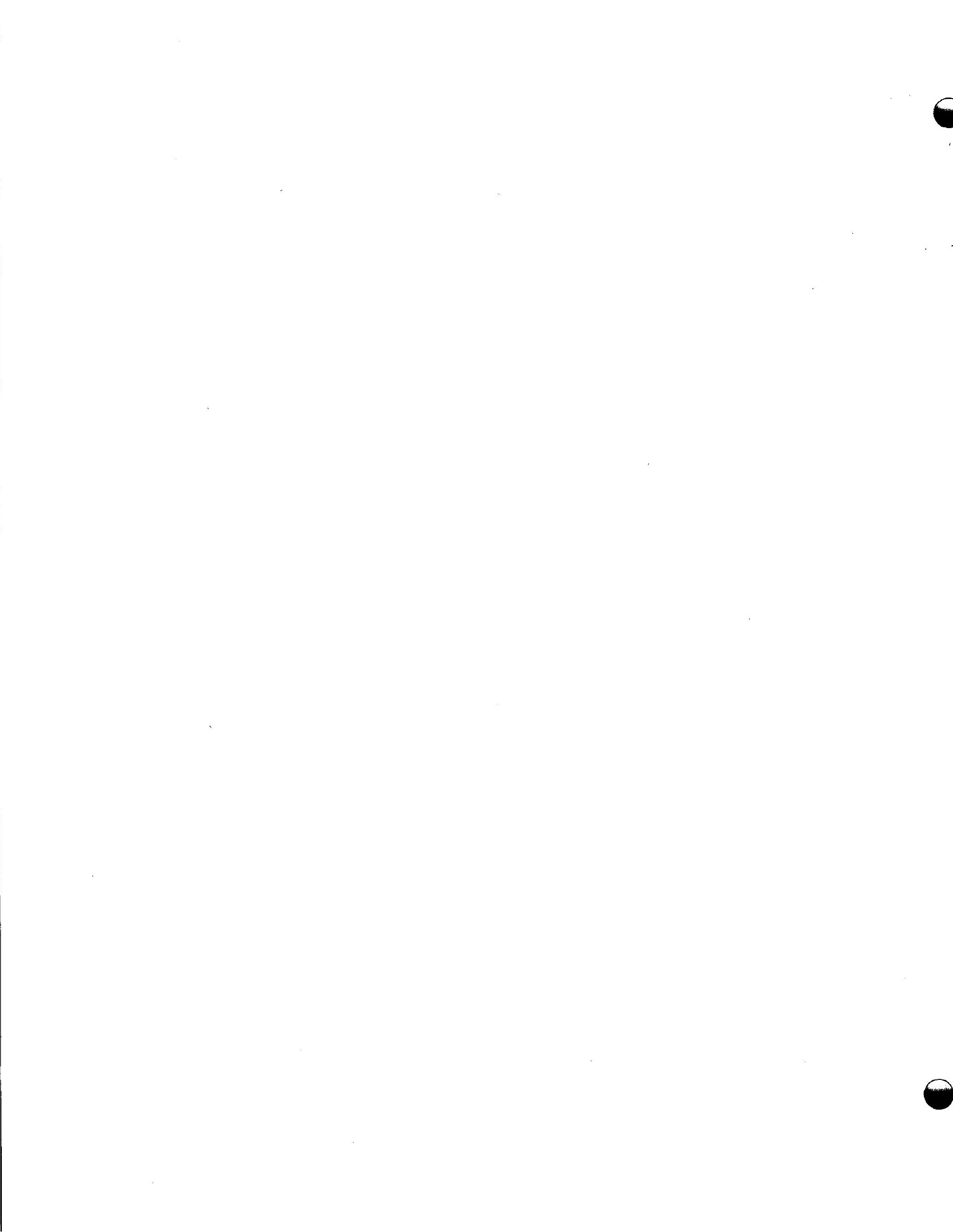

0 
$P=1$

PEBBLE-BED REACTOR MATERIALS (S \& P)

W. S. Diethorn and W. H. Goldthwaite

In support of the Pebble-Bed Reactor program Battelle is studying the mechanical properties and fission-gas retention of fueled-graphite spheres. The program consists of laboratory evaluation, fabrication of coated fuel particles, and irradiation-capsule studies.

\section{LABORATORY EVALUATION OF FUELED-GRAPHITE SPHERES}

M. C. Brockway and A. K. Smalley

Behavior in impact and compression tests and the coating integrity of coated fueled-graphite spheres are being studied with specimens received from commercial vendors. Most of the work this month was devoted to the evaluation of candidate spheres for Sweep Capsule SP-5. Work in the permeability and self-welding studies will be postponed until laboratory evaluation in preparation for this capsule is completed.

\section{FABRICATION DEVELOPMENT OF $\mathrm{Al}_{2} \mathrm{O}_{3}-\mathrm{CLAD} \mathrm{UO}_{2}$ FUEL PARTICLES}

\section{Sintered Cladding}

A. K. Smalley and W. H. Duckworth

Work in this phase of the program has been terminated.

Vapor-Deposited Cladding

T. E. Cook, J. M. Blocher, and A. K. Smalley

The preparation and evaluation of $\mathrm{UO}_{2}$ having a vapor-deposited $\mathrm{Al}_{2} \mathrm{O}_{3}$ cladding are continuing. Batches containing both natural and enriched $\mathrm{UO}_{2}$ have been prepared and incorporated into graphite spheres for fission-gas release studies.

One natural batch having a cladding thickness of $40 \mu$ was the rmally cycled between room temperature and $2500 \mathrm{~F}$ in air, and then weighed. A sample was heated in air in a covered platinum crucible for $15 \mathrm{~min}$, and then allowed to cool rapidly by removing the crucible from the furnace. The sample went through nine of these heatquench cycles. A small weight loss, comparable to that reported last month (BMI-1409) 
for a similar sample heated in air for $1 \mathrm{hr}$ at $1200 \mathrm{~F}$, was observed after the third cycle. No further weight change was observed after the remaining six cycles. Microscopic examination of the sample after the ninth cycle revealed cracks in about 1 per cent of the particles. Plans are under way to the rmally cycle clad particles in an inert atmosphere to determine the effect of heating and quenching.

An enriched batch, in which cladding thicknesses ranged from 50 to $60 \mu$, was prepared this month. The cladding was applied in five steps. Unlike the case with the natural particles prepared last month, three distinct layers were detected in the cladding. Petrographic analysis of the particles showed that the laminar cladding ranged in thickness from 50 to $60 \mu$. Chemical analyses showed that the clad particles contain $36.0 \mathrm{w} / \mathrm{o}$ of $\mathrm{UO}_{2}$. The lattice parameter of the $\mathrm{UO}_{2}$ (X-ray diffraction) is $5.4710 \pm$ $0.0005 \mathrm{~A}$, equivalent to an oxygen-to-uranium ratio of $2.008 \pm 0.005$. The $\mathrm{Al}_{2} \mathrm{O}_{3}$ is corundum $\left(\dot{\alpha}-\mathrm{Al}_{2} \mathrm{O}_{3}\right)$, having an average crystal size well below $5 \mu$. The average crystal size of the $\mathrm{UO}_{2}$ is about $5 \mu$. The refractive index corresponds very closely to that of stoichiometric $\mathrm{UO}_{2}$. Metallographic examination and spectrographic analysis are in progress.

\section{Carburization Studies}

A. F. Gerds

A heat treatment $(2500 \mathrm{~F})$ of baked compacts containing vapor-deposited $\mathrm{Al}_{2} \mathrm{O}_{3}-$ clad UO2 particles in graphite matrices is in progress. Specimens will be examined metallographically after 170,500 , and $1000 \mathrm{hr}$ to determine the compatibility of the se coated particles with graphite.

\section{FISSION-PRODUCT RELEASE FROM FUELED-GRAPHITE SPHERES}

\section{W. S. Diethorn}

In this phase of the program coated, fueled-graphite spheres and clad $\mathrm{UO}_{2}$ particles are neutron activated and then studied for fission-gas release during postirradiation heating. Spheres showing good fission-gas retention are advanced to the in-pile irradiation study. The in-pile study includes high-flux static capsules and low- and high-flux sweep capsules.

\section{Neutron-Activation Studies}

\section{H. S. Rosenberg}

Two batches of natural, vapor-deposited $\mathrm{Al}_{2} \mathrm{O}_{3}$-clad $\mathrm{UO}_{2}$ particles and graphite spheres containing particles from these batches were ne utron activated this month (Tables $\mathrm{P}-1$ and $\mathrm{P}-2$ ). Alpha assays of the unirradiated particles in an internal, flow 
$P-3$

TABLE P $\sim$. NEUTRON-ACTIVATION RESULTS FOR NATURAL $\mathrm{Al}_{2} \mathrm{O}_{3}$-CLAD UO 2 PARTICLES

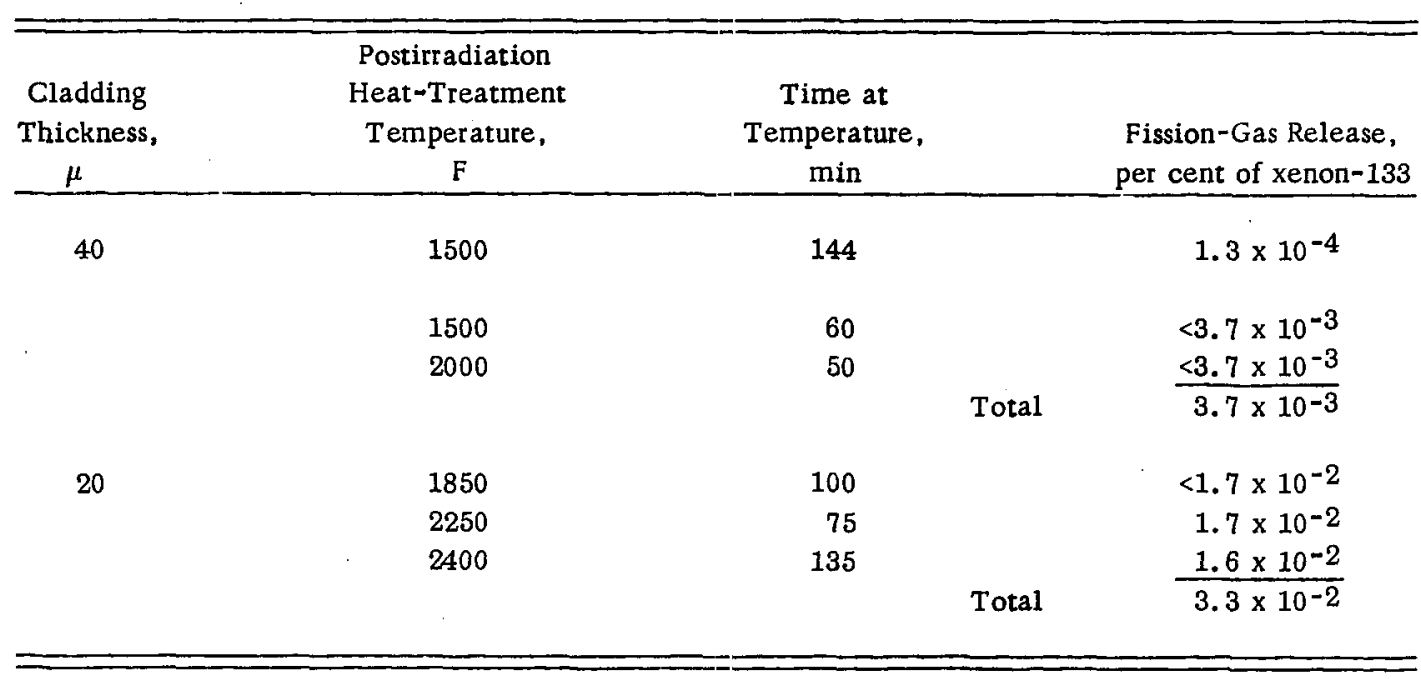

TABLE P-2. NEUTRON-ACTIVA TION RESLILTS FOR FUELED-GRAPHITE SPHERES(a)

\begin{tabular}{|c|c|c|c|c|c|}
\hline Sphere & $\begin{array}{c}\text { Cladding } \\
\text { Thickness, } \\
\mu \\
\end{array}$ & $\begin{array}{c}\text { Postirradiation } \\
\text { Heat-Treatment } \\
\text { Temperature, } \\
\text { F }\end{array}$ & $\begin{array}{c}\text { Time at } \\
\text { Temperature, } \\
\text { min }\end{array}$ & & $\begin{array}{l}\text { Fission-Gas Release, } \\
\text { per cent of xenon } 133\end{array}$ \\
\hline \multirow[t]{5}{*}{437} & 20 & 1650 & 80 & & $<8.1 \times 10^{-4(b)}$ \\
\hline & & 1800 & 50 & & $1.6 \times 10^{-3}$ \\
\hline & & 2200 & 60 & & $4.9 \times 10^{-3}$ \\
\hline & & 2350 & 30 & & $2.6 \times 10^{-2}$ \\
\hline & & & & Total & $3.3 \times 10^{-2}$ \\
\hline \multirow[t]{7}{*}{449} & $40-60$ & 1500 & 270 & & $7.5 \times 10^{-4}$ \\
\hline & & 1900 & 60 & & $<9.4 \times 10^{-4(b)}$ \\
\hline & & (cooled to $600 \mathrm{~F}$ ) & & & $\cdot$ \\
\hline & & 1900 & 60 & i & $<9.4 \times 10^{-4(b)}$ \\
\hline & & (cooled to $600 \mathrm{~F}$ ) & & & \\
\hline & & 1900 & 135 & & $\leq 9.4 \times 10^{-4(b)}$ \\
\hline & & & & Total & $9.4 \times 10^{-4}$ \\
\hline
\end{tabular}

(a) Containing vapor-deposited $\mathrm{Al}_{2} \mathrm{O}_{3}$-clad natural $\mathrm{UO}_{2}$.

(b) No detectable release, upper limit. 


$$
\mathrm{P}-4
$$

proportional counter-show that uranium contamination in the cladding surface is probably responsible for the xenon-133 release listed at the lowest temperatures in Table P-1. The totals are higher and suggest diffusion release of xenon- 133 .

Results in Table $\mathrm{P}-2$ show that the claddings are not damaged during sphere fabrication and that thermal-cycling of the spheres does not damage the claddings.

\section{In-Pile Capsule Experiments}

D. Stahl, G. E. Raines, and W. H. Goldthwaite

$\underline{\mathrm{SP}-4}$

The BRR irradiation of this static capsule containing six fully enriched graphite spheres is operating satisfactorily with individual specimen-surface temperatures ranging from 1500 to $1800 \mathrm{~F}$. The planned termination date of this experiment is midMarch, when the estimated fission burnup will be 6 to $7 \mathrm{w} / 0$ of the uranium-235. The spheres will be exa.nined in the Battelle Hot-Cell Facility.

$\underline{\mathrm{SP}-5}$

The target date for BRR insertion of this high-flux sweep-capsule experiment, originally scheduled for mid-March, may be delayed until April. The schedule will depend on specimen availability.

Based on previous sweep-capsule experience in this program, it is planned to follow the release of krypton-87, krypton-88, and krypton-85m and xenon- 133 and xenon135 during the in-pile history. A trap containing steel mesh will be placed in the exit line of the capsule in order to catch solid daughter fission products resulting from the decay of very-short-lived fission gases during residence of the latter in the trap. Radiochemical analyses of the washings from this trap should provide indirect estimates of the rate of release of short-lived gases. A search for the daughters of krypton-89, xenon140 , and xenon- 141 is planned.

The capsule and trap are well into the fabrication stage.

\section{$\underline{\text { SPF-1 }}$}

Irradiation of this low-flux furnace capsule containing a single $\mathrm{UC}_{2}$ fueled-graphite sphere with a pyrolitic carbon coating was terminated during January. Latest results of the gas sampling were reported in BMI-1409. The capsule is now being stored in the pool of the BRR. There are no plans to examine the specimen. 


$$
\text { P-5 and P-6 }
$$

$\underline{\text { SPF-2 }}$

Furnace Capsule SPF-2, containing a natural $\mathrm{UO}_{2}$ fueled-graphite sphere, coated with silicon carbide, was inserted in the BRR. on February 10. Gas samples were collected at $200,1000,1500$, and $1900 \mathrm{~F}$. Fission-gas retention is excellent. Very small amounts of unidentifiable fission-gas species were released below $1500 \mathrm{~F}$. Krypton-87, krypton-88, and krypton-85m and xenon- 133 and xenon- 135 were found in sufficient amounts in the 1500 and $1900 \mathrm{~F}$ samples, collected as long as $4 \mathrm{hr}$, to permit identification and assay. Krypton- 88 is uncertain. The fission-gas assays will be completed in early March and reported next month. Based on the known detection sensitivity for krypton-87, the estimated $R / B$ for this species at $1000 \mathrm{~F}$ is about $10^{-6}$. One or two additional gas samples are planned at $1900 \mathrm{~F}$ before termination of this experiment.

\section{SPF-3}

Irradiation of Furnace Capsule SPF-3, containing a fueled-graphite sphere (499, Table $\mathrm{P}-2$ ), is planned in March. The fuel is minus 100 plus 140 -mesh natural $\mathrm{UO}_{2}$ clad with 40 to $60 \mu$ of vapor-deposited $\mathrm{Al}_{2} \mathrm{O}_{3}$. The scheduling and in-pile time of this capsule will depend on the availability of the gas train presently committed to the SP-5 capsule experiment. 


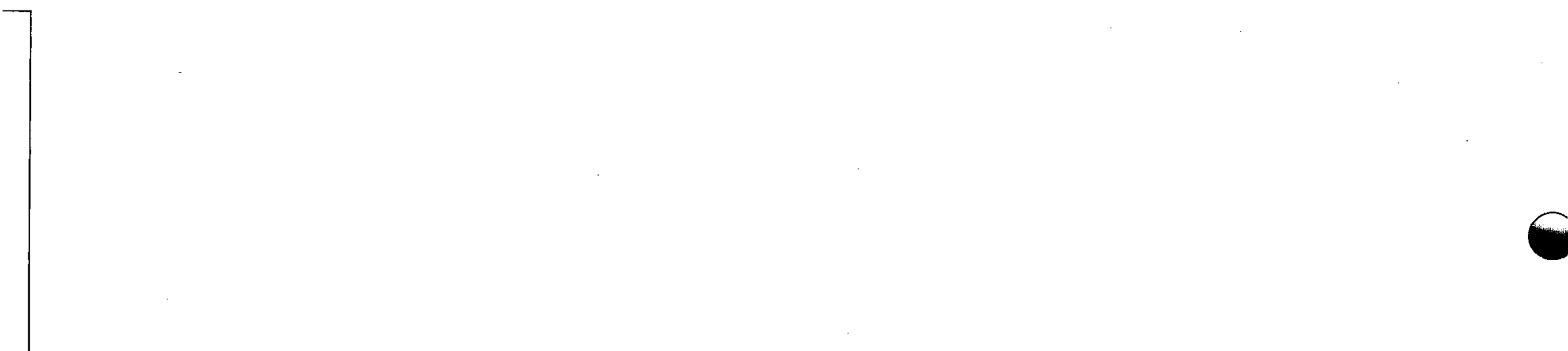

.

6
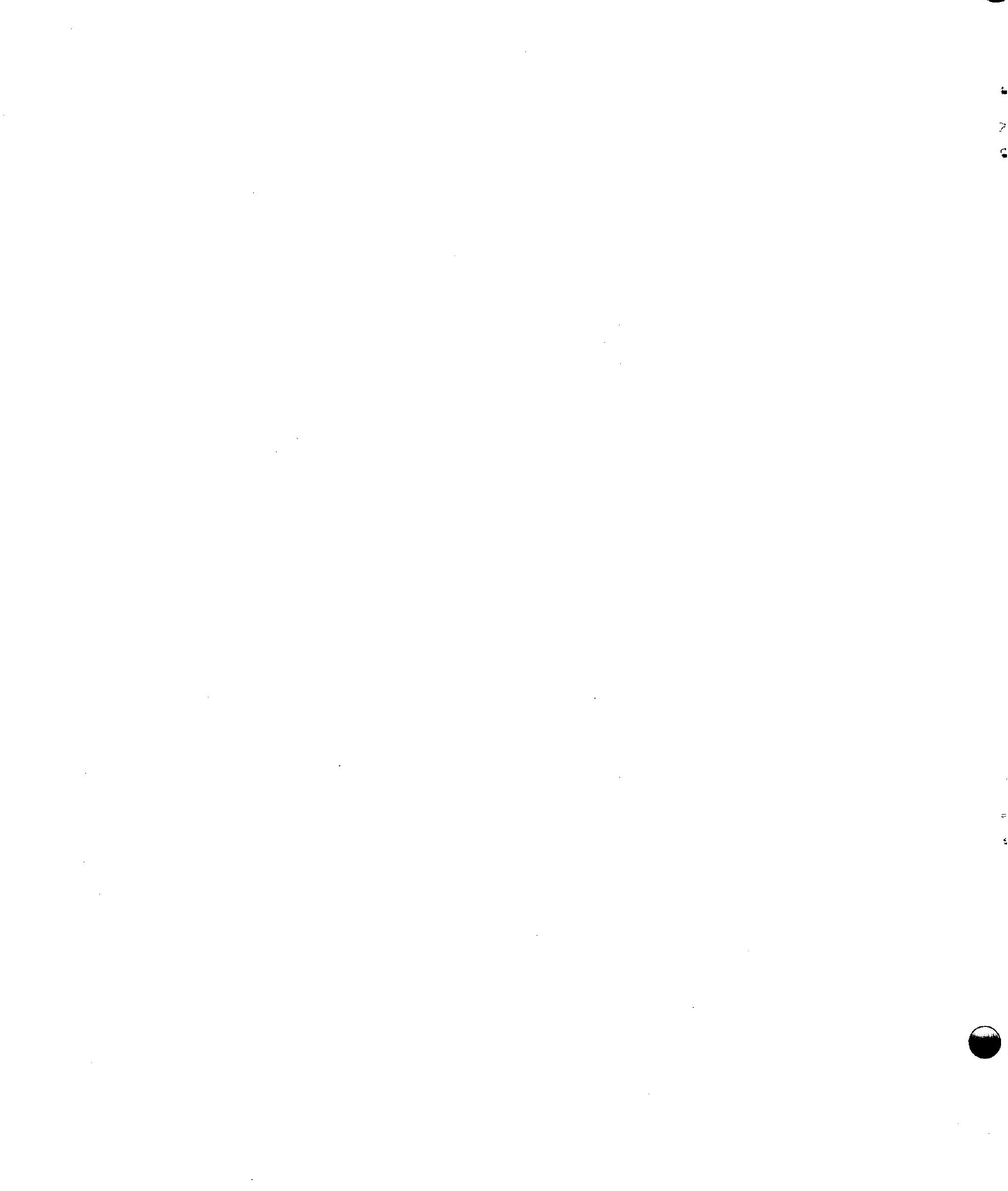
Q- 1

\title{
TANTALUM AND TANTALUM ALLOYS FOR LAMPRE APPLICATIONS (LASL)
}

\author{
J. H. Stang
}

In studies of tantalum and tantalum-base alloys being conducted for the LAMPRE program at Los Alamos Scientific Laboratory, recent activity has included the processing of a group of arc-melted binary tantalum alloys to strip stock, additional determinations of the physical properties of irradilated tensile specimens of tantalum, and $X$-ray lattice-parameter measurements of tantalum-oxygein materials to investigate interstitial solid solubility. The latter are the first experimental data obtained in the phase-identification study of tantalum.

Irradiated tantalum has been found to exhibit markedly different properties than the unirradiated material. The alterations include higher strength and hardness, although ductility is not seriously impaired. To check dosimeter-based tantalum-totungsten conversions during the irradiations. chemical analyses for tungsten have recently been made on irradiated samples, tungsten contents indicated by the two methods are, for i.s apparent reason, considerably different.

Development of Container Materials for LAMPRE Applications

D. C. Drennen, C. J. Slunder, and J. G. Dunleavy

As reported in BMI- 1409,16 button specimens of binary tantalum alloys were produced during January; the alloying additions were hafnium, iron, silicon, thorium, and zirconium. These buttons are now being processed to $0.030-\mathrm{mil}$ strip to provide specimens for LASL corrosion tests. As a first step, the buttons were cold pressed ( 19 to 40 per cent reduction) to a thickness of about 0.26 in. to break up the cast structure; the pieces were then machined to remove surface contaminants. Generally, the pressing behavior of the alloys was good. However, the tantalum- 1 w/o silicon alloy cracked immediately upon application of the load. No attempt was made to press the tantalum-3 w/o silicon alloy since it cracked into several pieces during arc casting.

The processing of the workable alloys is continuing. Concurrently, sections of the arc-cast button specimens are being prepared for microstructural examination and hardness determination.

\section{Effect of Irradiation Damage of Tantalum}

C. K. Franklin, F. R. Shober, and R. F. Dickerson

A summation of room-temperature tensile-property data for both irradiated and unirradiated tantalum was presented in BMI-1407. Increases in strength and decreases in ductility were evident as a result of irradiation. Unirradiated tantalum annealed at 
$1400 \mathrm{C}$ for $1 \mathrm{hr}$ showed an 0.2 per cent offset yield strength of about 30,000 psi. After irradiation, the material showed yield strengths as high as 84,000 psi for specimens irradiated for seven MTR cycles. A decrease in tensile ductility was also observed in the irradiated material. However, the irradiated specimens exhibited no brittle behavior when tested in bending.

Increases in the hardness of the material also accompanied irradiation. Hardness impressions were made on both unirradiated and irradiated samples with a Tukon hardness tester, using a Knoop diamond indenter and a 100-g load. The unirradiated tantalum showed an average of hardness of $103 \mathrm{KHN}$, while the irradiated specimens showed average hardnesses of 274 and $309 \mathrm{KHN}$ for irradiations of four and seven cycles, respectively.

Samples of the irradiated material were dissolved, and the presence of tungsten was determined by colorimetric analysis. The results of this test indicate that the conversion of tantalum to tungsten was not as great as expected. Only $0.7 \mathrm{w} / \mathrm{o}$ tungsten was formed in the tantalum during the four-cycle irradiation period, and only about $1.2 \mathrm{w} / \mathrm{o}$ tungsten was formed in seven cycles. Dosimeter analsyes indicated that sufficient thermal fluxes were present to produce at least twice these amounts. This discrepancy between the chemical analyses for tungsten and the amount of tungsten predicted by dosimeter analyses is not fully understood.

Dosimeter analyses will be made to determine the total fast-neutron flux accumulated during the irradiation periods.

\section{Precipitate Phase Identification and Interstitial-Type Solid}

\section{Solubility in Tantalum}

J. B. Schroeder, D. A. Vaughan, and C. M. Schwartz

The interstitial solid solubility of carbon, nitrogen, and oxygen in tantalum is being investigated over the temperature range 500 to $1500 \mathrm{C}$. The composition range of interest will include supersaturated specimens in order to obtain the initial precipitate phases for identification. The purpose of these studies is to aid LASL in understanding the role of interstitial impurities in the corrosion of tantalum by plutonium fuel mixtures.

The X-ray lattice-parameter determinations on the oxygen series containing 0 to 4 a/o addition were completed. The experimental values were consistently larger than those reported in the literature* and those previously measured at BMI for high-purity tantalum.

Additional analytical work is in progress to explain these data. Carbon, hydrogen, and nitrogen are considered to be the most likely contaminants. The preparation of the nitrogen series is being delayed until the present analytical work is completed.

\footnotetext{
"Wasilewski, R. J., "The Solubility of Oxygen in, and the Oxides of, Tantalum", J. Am. Chem. Soc., 75, 1001-2 (February 20, 1953).
} 


$$
\mathrm{R}-1 \text { and } \mathrm{R}-2
$$

DEVELOPMENTAL STUDIES FOR THE PWR (BAPD)

R. W. Dlayton

Further studies of the preparation of large flat-plate PWR fuel plates will be conducted by Bettis, and no further work has been done.

\section{Fabrication of Large-Scale PWR-Type Fuel Plates}

S. J. Paprocki, E. S. Hodge, and C. C. Simons

Bettis is presently considering the preparation of Zircaloy-2-clad compartmented uranium dioxide fuel plates for PWR Core 2 on a production basis. The feasibility of preparing small-scale fuel plates of this type, approximately 15 in. long and 15 core compartments wide by gas-pressure bonding, has been established. During the initial process study, the length of the specimens was increased from 15 to 33 to 40 in., while the width was held constant. Favorable results were also achieved with these larger scale specimens. The final scale-up to full size is being investigated at Bettis for production considerations; consequently, it is not planned to further study bonding of largescale PWR-type fuel plates.

This completes the work on this project. 

•

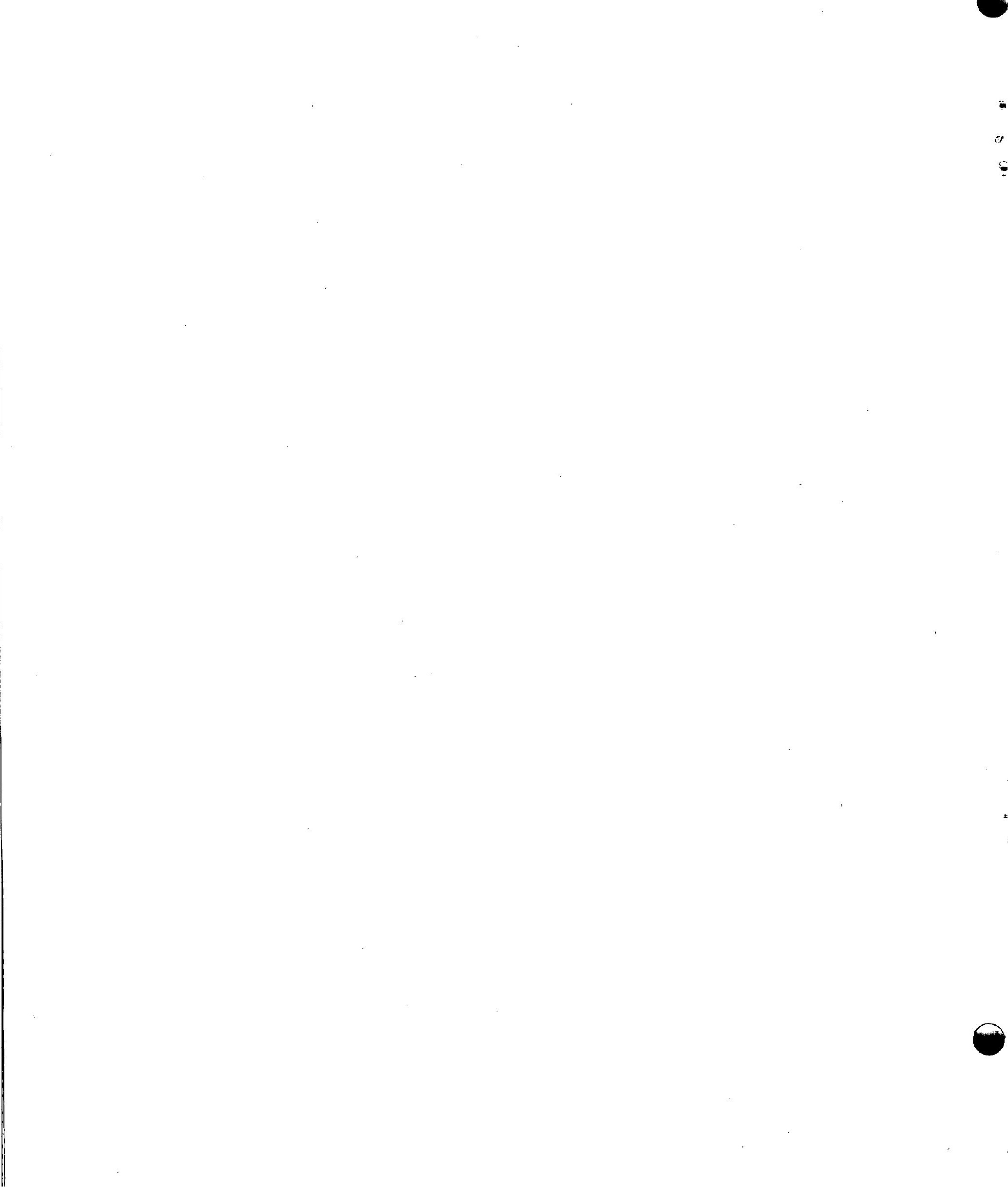

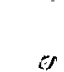

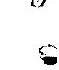

.

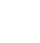<smiles>[CH]C</smiles>

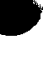

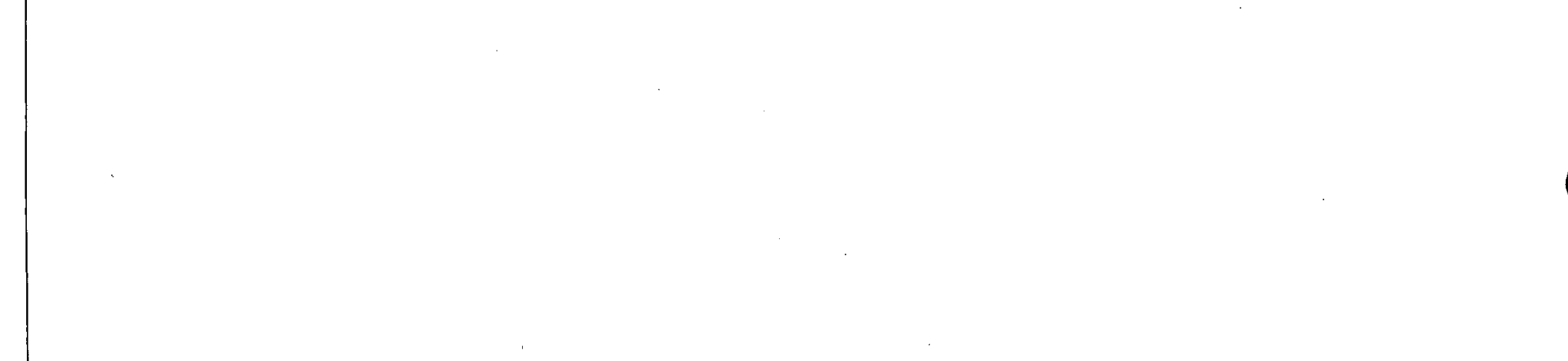


S- 1

DEVELOPMENT OF MATERIALS FOR THE MGCR AND HTGR (GA)

W. C. Riley

Research on core materials for both the MGCR and HTGR is in progress at Battelle. For the MGCR, the major effort is on development and evaluation of $\mathrm{UO}_{2}$ dis persions in $\mathrm{BeO}$ or $\mathrm{Al}_{2} \mathrm{O}_{3}$ and dispersions of $\mathrm{JC}$ or $\mathrm{UC}_{2}$ in graphite. Currently, the evaluation consists mainly of static-capsule irradiation in the MTR.

For the HTGR, vapor deposition is being investigated as a method of preparing and coating uranium and thorium carbide powder.

High-Burnup Irradiation Effects in Fuel Materials

W. E. Murr, N. E. Miller, J. E. Gates, and R. F. Dickerson

A program is in progress that is designed to study the radiation stability of ceramic-type fuels after various levels of burnup at specimen-surface temperatures near $1500 \mathrm{~F}$. The fuels, of interest to the MC;CR concept, include specimens composed of about 20 volume per cent uranium dioxide in beryllium oxide, 20 volume per cent uranium dioxide in aluminum oxide, 20 volume per cent uranium monocarbide ingraphite, and 20 volume per cent uranium dicarbide in graphite.

The evaluation of beryllium oxide-matrix and graphite-matrix specimens consists of the irradiation and examination of 24 specimens in 4 capsules equipped with heaters and thermocouples for maintaining and monitcring specimen temperatures. Each capsule contains two specimens of each type of fuel; each specimen is composed of four cylindrical pellets approximately $0.222 \mathrm{in.}$ in diameter by $0.250 \mathrm{in}$. long sealed in Type 316 stainless steel tubing under a helium atmosphere.

The initial capsule of this series was irradiated in the Battelle Research Reactor to specimen burnups of about 1.1 to 1.7 uranium a/o at surface temperatures $\mathrm{r}$ anging from 130 to $1550 \mathrm{~F}$. Postirradiation examination revealed that all six specimens were in good physical condition. Detailed information concerning the examination was reported in BMI-1366 and BMI- 1377.

The three additional capsules have been in the MTR since the beginning of MTR Cycle 125 and have just completed their tenth irradiation cycle, Cycle 134. The electrical-heater difficulties reported for Capsule BMI-31-1 during MTR Cycle 133 have been corrected, and all three heaters and three of the six original thermocouples in the capsule are again in operation. The remaining two capsules are operating satisfactorily with all three heaters and four of the six thermocouples functional.

Table S-l gives the thermocouple temperatures and heater-power requirements for maintaining the capsules in the desired temperature range during MTR Cycle 134. Capsule BMI-31-3 is located in the lowest flux position and requires the largest amount of auxiliary heat to operate near $1500 \mathrm{~F}$. 


\section{S-2}

TABLE S-1. TEMPERATURE AND ELECTRICAL-HEATER POWER CONSUMPTION FOR CAPSULES BMI-31-1, BMI-31-2, AND BMI-31-3 DURING MTR CYCLE 134

\begin{tabular}{|c|c|c|c|c|c|c|c|}
\hline \multirow[b]{2}{*}{ Capsule } & \multirow{2}{*}{$\begin{array}{c}\text { Electrical-Heater Power } \\
\text { Consumption, w }\end{array}$} & \multicolumn{6}{|c|}{ Thermocouple Reading(a), F } \\
\hline & & No. 1 & No. 2 & No. 3 & No. 4 & No. 5 & No. 6 \\
\hline $\mathrm{BMI}-31-1$ & 960 & -- & -- & $1490^{(b)}$ & 1420 & 1215 & - \\
\hline BMI $-31-2$ & 2200 & 1380 & - & $1445^{(b)}$ & - & $1410(c)$ & 1410 \\
\hline BMI $-31-3$ & 2880 & 1440 & $1510^{(b)}$ & -- & 1480 & -- & 1420 \\
\hline
\end{tabular}

(a) Specimen-surface temperatures are calculated to be 25 to $30 \mathrm{~F}$ higher.

(b) Controlling thermocouple.

(c) Temperature is erratic.

It is planned to retain all three capsules in the MTR at least until the end of Cycle 143 (approximately August 1, 1960). At this time, the specimens in Capsule BMI31-1 will have approximately 20 to 25 uranium a/o burnup, and the specimens in Capsule BMI-31-2 and BMI-31-3 will have approximately 12 and 9 uranium a/o burnup, respectively.

A single instrumented capsule containing $\mathrm{Al}_{2} \mathrm{O}_{3}-\mathrm{UO}_{2}$ samples was irradiated in the BRR for six reactor cycles. This capsule has been sent to General Atomic for hotcell examination.

\section{Carbon-Transport Corrosion Studies}

N. E. Miller, D. J. Hamman, J. E. Gates, and W. S. Diethorn

Selected metal and graphite specimens have been exposed to radiation in heliumfilled quartz tori designed to promote convective flow of the helium and gaseous impurities past the specimens. All experimental work has been completed, and a topical report is being prepared.

\section{Preparation and Coating of Uranium and Thorium Carbide Powders}

J. H. Oxley, R. B. Landrigan, A. C. Secrest, C. F. Powell, and J.M. Blocher, Jr.

An experimental program is under way to determine the feasibility of preparing uranium and thorium carbide powders and, subsequently, to coat these powders with carbon, niobium carbide, or zirconium carbide films by vapor-deposition techniques. Parallel efforts on both preparation and coating are being carried out. 


\section{S-3}

The design and construction of the equipment were completed in February, and exploratory studies on the carbon deposition have been initiated. A substitute for uranium and/or thorium carbide powder is being used in this initial phase of the coating study.

It is planned to use a uranium tetraiodide feed material in the initial experiments to prepare uranium carbide. This material was selected because uranium idoides are the most volatile of the uranium halides and can be most readily converted to carbides, and because the common reductant iodides (i.e., $\mathrm{MgI}_{2}, \mathrm{ZnI}_{2}$, etc.) are the most volatile of the reductant metal halides. The data in Table $S-2$ show the relative advantages of the iodides. However, if experimental resilts suggest that a shift to a uranium chloride or fluoride feed would be advantageous, the program will be modified immediately. Uranium tetradiodide has been ordered from a commercial vendor, and a lot of this material has been prepared at Battelle to minimize loss of time due to extended delivery dates for this item. 
TABLE S-2. FREE-ENERGY CHANGES FOR REACTIONS INVOLVING URANIUM MONOCARBIDE ${ }^{(a)}$

\begin{tabular}{|c|c|c|c|c|c|c|c|c|c|c|}
\hline \multirow[b]{2}{*}{ Reaction } & \multicolumn{2}{|c|}{ Melting Points, $\mathrm{C}$} & \multicolumn{2}{|c|}{ Boiling Points, $\mathrm{C}$} & \multicolumn{6}{|c|}{ Free-Energy Change(b) at Indicated Temperature, kcal } \\
\hline & $\mathrm{UX}_{3}$ & $\mathrm{MX}_{2}$ & $\mathrm{UX}_{3}$ & $\mathrm{MX}_{2}$ & $727 \mathrm{C}$ & $927 \mathrm{C}$ & $1127 \mathrm{C}$ & $1327 \mathrm{C}$ & $1527 \mathrm{C}$ & $1727 \mathrm{C}$ \\
\hline $\mathrm{UF}_{3}+\mathrm{C}+3 / 2 \mathrm{H}_{2} \rightarrow \mathrm{UC}+3 \mathrm{HF}$ & 1427 & -- & 2277 & -- & +67 & +56 & +44 & +32 & +21 & +10 \\
\hline $\mathrm{UCl}_{3}+\mathrm{C}+3 / 2 \mathrm{H}_{2} \rightarrow \mathrm{UC}+3 \mathrm{HCl}$ & 1116 & -- & 1727 & -- & +70 & +61 & +51 & +42 & +33 & +24 \\
\hline $\mathrm{UBr}_{3}+\mathrm{C}+3 / 2 \mathrm{H}_{2} \rightarrow \mathrm{UC}+3 \mathrm{HBr}$ & 752 & -- & 1576 & -- & +69 & +63 & +57 & +50 & +44 & +41 \\
\hline $\mathrm{UI}_{3}+\mathrm{C}+3 / 2 \mathrm{H}_{2} \rightarrow \mathrm{UC}+3 \mathrm{HI}(\mathrm{c})$ & 757 & -- & 1427 & -- & +55 & +46 & +38 & +30 & +24 & +20 \\
\hline $\mathrm{UF}_{3}+\mathrm{C}+3 / 2 \mathrm{Zn} \rightarrow \mathrm{UC}+3 / 2 \mathrm{ZnF}_{2}$ & 1427 & 872 & 2277 & 1497 & +58 & +58 & +62 & +65 & +72 & +75 \\
\hline $\mathrm{UCl}_{3}+\mathrm{C}+3 / 2 \mathrm{Zn} \rightarrow \mathrm{UC}+3 / 2 \mathrm{ZnCl}_{2}$ & 1116 & 365 & 1727 & 732 & +35 & +32 & +29 & +27 & +24 & +21 \\
\hline $\mathrm{UBr}_{3}+\mathrm{C}+3 / 2 \mathrm{Zn} \rightarrow \mathrm{UC}+3 / 2 \mathrm{ZnBr}_{2}$ & 752 & 394 & 1576 & 697 & +28 & -- & -- & -- & -- & -- \\
\hline $\mathrm{UI}_{3}+\mathrm{C}+3 / 2 \mathrm{Zn} \rightarrow \mathrm{UC}+3 / 2 \mathrm{ZnI}_{2}$ & 757 & 446 & 1427 & 624 & -4 & -- & -- & -- & -- & -- \\
\hline $\mathrm{UF}_{3}+\mathrm{C}+3 / 2 \mathrm{Mg} \rightarrow \mathrm{UC}+3 / 2 \mathrm{MgF}_{2}$ & 1427 & 1263 & 2277 & 2227 & -71 & -71 & -70 & -61 & -54 & -48 \\
\hline $\mathrm{UCl}_{3}+\mathrm{C}+3 / 2 \mathrm{Mg} \rightarrow \mathrm{UC}+3 / 2 \mathrm{MgCl}_{2}$ & 1116 & 712 & 1727 & 1418 & -29 & -31 & -34 & -21 & -21 & -21 \\
\hline $\mathrm{UBr}_{3}+\mathrm{C}+3 / 2 \mathrm{Mg} \rightarrow \mathrm{UC}+3 / 2 \mathrm{MgBr}_{2}{ }^{2}$ & 752 & 710 & 1576 & 1230 & -32 & -31 & -30 & -30 & -- & -- \\
\hline $\mathrm{UI}_{3}+\mathrm{C}+3 / 2 \mathrm{Mg} \rightarrow \mathrm{UC}+3 / 2 \mathrm{MgI}_{2}$ & 757 & 650 & 1427 & 927 & -40 & -42 & -43 & -44 & -- & -- \\
\hline$\rightarrow \mathrm{C}+2 \mathrm{H}_{2}$ & -- & -- & -- & -- & -5 & -10 & -15 & -21 & -26 & -32 \\
\hline
\end{tabular}

(a) Sources of data:

Brewer, L., and Krikorian, J., "High-Temperature Studies: I. Reactions of the Refractory Silicides With Carbon and With Nitrogen; II. Thermodynamic $x$ Properties of the Carbides; III. Heat of Formation of the $3 \pi \mu$ State of $C_{2}$ from Graphite", UCRL-2888 (April, 1955). (Uranjum monocarbide.)

Farr, J. D., Huber, E. J., Head, E. L., and Holley, C. E. , "The Preparation of Uranium Monocarbide and Its Heat of Formation", J. Phys. Chem. , 63, 1455 (1959). (Uranium monocarbide.)

Glassner, A., "The Thermochemical Properties of the Oxide, Fluorides, and Chlorides to $2500^{\circ} \mathrm{K}$, ANL-5750 (1957). (All metal fluorides and chlorides.)

Katz, J. J., and Rabinowitch, E., Chemistry of Uranium, McGraw-Hill Book Company, New York (1951), Paper No. 58 by MacWood, G. E.

(Uranium bromides and iodides.)

Quill, L. L, The Chemistry and Metallurgy of Miscellaneous Materials: Thermodynamics, McGraw-Hill Book Company, New York (1950), Paper No. 6 by Brewer, L., Bromley, L. A., Gilles, P. W., and Lofgren, N. L. (Metal bromides and iodides other than uranium.)

Rossini, F. D. , Cowie, P. A., Ellison, F. O., and Browne, C. C. , "Properties of Titanium Compounds and Related Substances", ONR ACT -17 (1956). (Hydrogen halides, atomic halides.)

(b) The free-energy changes are given for the reactants and products in their normal phases at the indicated temperatures.

(c) HI dissociates to $1 / 2 \mathrm{H}_{2}+\mathrm{I}$ at the higher temperatures, so the net reaction is actually more favorable than indicated by the estimated free-energy change. A similar but less pronounced dissociation of $\mathrm{ZnI}_{2}$ and $\mathrm{MgI}_{2}$ will also take place at high temperatures. 
$\mathrm{T}-1$

DEVELOPMENTAL STUDIES FOR THE SM-2 (ALCO)

S. J. Paprocki

The work presented in this section is being conducted in assistance to Alco Products and is concerned with the development of fuel, absorber, and suppressor materials for the $S M-2$.

Prototype fuel plates are being fabricated for subsequent irradiation testing in a WTR loop and in the SM- 1 reactor core. The fabricated plates will be shipped to Alco for welding into composite elements. Studies concerned with retention of boron as a burnable poison are continuing. These studies include investigation of the effects of fabrication variables and heat treatments in an effort to determine the mechanism of boron loss.

Prototype and alternate SM-2 fuel materials are being irradiated in the MTR and ETR. At the end of March, it is calculated that the burnup will range from about 40 to 70 a/o of contained uranium-235. The capsules will be discharged and returned to Battelle for postir adiation evaluation. Additional capsules instrumented with both thermocouples and auxiliary heaters have been shipped to NRTS for insertion in the ETR.

Materials Development

S. J. Paprocki, D. L. Keller, G. W. Cunningham, A. K. Foulds, and D. E. Lozier

Fabrication techniques are being developed for use in preparing fuel plates and absorber plates for the SM-2 reactor. Full-size stainless-clad stainless-UO 2 dispersion fuel plates containing fully enriched $\mathrm{UO}_{2}$ are also being prepared for incorporation in the SM-1 spike core and half-size plates are being prepared for insertion in a WTR loop.

Fuel Materials

The major effort on this program is being directed toward the fabrication of 38 full-size fuel plates and 9 half-width fuel plates which will be used to fabricate fuel elements for insertion into the SM-I reactor core and a WTR in-pile loop. The composition and dimensions of the fuel-plate cores are listed in Table $\mathrm{T}-1$. Unless otherwise indicated, all plates will contain a 1/2-in. -long by 0.030-in. -thick suppressor section of $16 \mathrm{w} / \mathrm{o} \mathrm{EU}_{2} \mathrm{O}_{3}$ dispersed in an elemental iron- $18 \mathrm{w} / 0$ chromium-9 w/o nickel matrix. The width will be identical to the fuel section. The full-size fuel plates will be clad with 0.005-in. -thick Type 347 low-cobalt low-tantalum stainless steel. A 500-1b heat of this steel has been prepared from electrolytic iron, chromium, and nickel and a special high-purity niobium. Five 100-lb ingots were cast, forged, and rolled to plate and sheet. Picture-frame packs and cover plates have been machined for fuel-plate preparation. Complete analyses of the fabricated rnaterial have not been obtained, but it is known that specifications regarding cobalt and tantalum content have been met. The 
$\mathrm{T}-2$

TABLE T-1. FUEL PLATES FOR IRRADIATION TESTING IN SM-1 AND WTR REACTORS

\begin{tabular}{|c|c|c|c|c|c|c|}
\hline $\begin{array}{l}\text { Number of } \\
\text { Plates }\end{array}$ & Designation & Fuel & $\begin{array}{l}\text { Testing } \\
\text { Reactor }\end{array}$ & Burnable Poison (a) & Supressor & Active Core Size \\
\hline 2 & Core II reference & $24.2 \mathrm{w} / \mathrm{o}$ Geneva $\mathrm{UO}_{2}$ & $S M-1$ & $\mathrm{~B}_{4} \mathrm{C}$ & None & 2.650 by 0.030 by 22 in. \\
\hline 22 & SM-2 reference & $26 \mathrm{w} / \mathrm{o}$ spherical $\mathrm{UO}_{2}$ & $S M-1$ & $\mathrm{ZrB}_{2}$ & $\mathrm{Eu}_{2} \mathrm{O}_{3}$ & Ditto \\
\hline 2 & $\begin{array}{l}\text { SM-2 reference, } \\
\text { no boron }\end{array}$ & 26 w/o spherical $\mathrm{UO}_{2}$ & $S M-1$ & $\begin{array}{l}\text { Boron-stainless } \\
\text { picture frame }\end{array}$ & None & Ditto \\
\hline 2 & SM-2 reference & $26 \mathrm{w} / \mathrm{o}$ Geneva $\mathrm{UO}_{2}$ & $S M-1$ & $\mathrm{ZrB}_{2}$ & $\mathrm{Eu}_{2} \mathrm{O}_{3}$ & Ditto \\
\hline 2 & SM-2 green compact & $26 \mathrm{w} / \mathrm{o}$ spherical $\mathrm{UO}_{2}$ & $S M-1$ & $\mathrm{ZrB}_{2}$ & $\mathrm{Eu}_{2} \mathrm{O}_{3}$ & Ditto \\
\hline 2 & SM-2 reference & $26 \mathrm{w} / \mathrm{o}$ spherical $\mathrm{UO}_{2}$ & $S M-1$ & $\mathrm{NbB}_{2}$ & $\mathrm{Eu}_{2} \mathrm{O}_{3}$ & Ditto \\
\hline 2 & SM-2 reference & $26 \mathrm{w} / \mathrm{o}$ spherical $\mathrm{UO}_{2}$ & $S M-1$ & Coated $\mathrm{ZrB}_{2}$ & $\mathrm{Eu}_{2} \mathrm{O}_{3}$ & Ditto \\
\hline 2 & SM-2 reference UN & $24.3 \mathrm{w} / \mathrm{o} \mathrm{UN}$ & $S M-1$ & $\mathrm{ZrB}_{2}$ & $\mathrm{Eu}_{2} \mathrm{O}_{3}$ & Ditto \\
\hline 2 & SM-2 reference UN & $24.3 \mathrm{w} / \mathrm{o} \mathrm{UN}$ & $S M-1$ & No boron & $\mathrm{Eu}_{2} \mathrm{O}_{3}$ & Ditto \\
\hline 9 & SM-2 reference & $26 \mathrm{w} / \mathrm{o}$ spherical $\mathrm{UO}_{2}$ & WTR & $\mathrm{ZrB}_{2}$ & $\mathrm{Eu}_{2} \mathrm{O}_{3}$ & 16 by 1.490 by 0.030 in. \\
\hline
\end{tabular}

(a) Boron content is $0.212 \mathrm{w} / \mathrm{o}$ except for the $\mathrm{B}_{4} \mathrm{C}$ specimen for which boron content cannot be predicted. 
$\mathrm{T}-3$

required maximum loading of cobalt cannot exceed $0.025 \mathrm{w} / 0$ and the maximum loading of tantalum cannot exceed $0.01 \mathrm{w} / \mathrm{o}$.

Because of close tolerances required on the supressor end of the fuel plate, an evaluation of the rolling schedule has been made in an attempt to select a roll schedule that will result in an optimum core structure with minimum tail effects at the suppressor end. The results are shown in Table $\mathrm{T}-2$. The plates rolled at $2000 \mathrm{~F}$ or a combination of 2000 and $2200 \mathrm{~F}$ were rolled primarily to study the effect on core structure. Since more stringering and fracturing of the $\mathrm{UO}_{2}$ occurred, it is not proposed to use any of these combinations. Best results regarding suppressor tail effects are obtained when the suppressor goes through on the leading erd of the first pass. It the plate is not flipped and reversed on each pass, the tail effects even on the leading edge become zccentuated. Also, since one end of the plate is constantly rolled at a lower temperature, a difference in core structure is possible. Since an optimum core structure is obtained when heavy reductions are used on the first pass, it appears desirable to maintain at least a 30 per cent reduction in thickness on the first pass. As indicated in Table $\mathrm{T}-2$, minimum tail effects are obtained when the 30 per cent reduction is used on the first two passes. Very light reductions should produce less tail effects, but an optimum core structure would not be obtained. More passes and longer fabrication times are expected to produce greater poron losses.

Compacts are being blended, pressed, and sintered, and fabrication of full-sized fuel plates has been initiated. Fabrication of the nine WTR plates is in progress and is expected to be completed within a few days.

Studies on boron loss during roll cladding have continued. It has been postulated that the rate of dissolution of $\mathrm{ZrB}_{2}$ is the rate-controlling factor. To gain additional evidence that the rate of boron removal from the surface is not rate controlling, a series of two specimens was fabricated in which one specimen was pickled to remove scale after each pass. Both specimens were air cooled after each pass and were held in the furnace for an identical period of time. The pickled specimen lost 9.14 per cent boron while the unpickled specimen lost 6.5 per cent boron. The difference in loss can probably be attributed to the removal of boroln-containing scale and metal after each pass. If the rate of boron removal at the surfaces were rate controlling, it would be expected that boron loss would be very great on the pickled surface, since the boron is removed after each pass and since oxygen in the atmosphere is more readily available to combine with the boron diffusing to the surface during annealing treatments. Additional studies using boron-stainless alloy cores are being made to verify the assumption that boron removal is not the rate-controlling factor in boron loss.

Comparison of boron loss after a $24-\mathrm{hr}$ anneal at $2050 \mathrm{~F}$ indicates that the rate of boron diffusion is not the controlling factor. After a standard fabrication procedure, a 5.65 per cent boron loss was observed and after the additional 24-hr anneal on a similar specimen a 17.8 per cent boron loss was observed. This loss is approximately 0.4 per cent boron per $\mathrm{hr}$ at $2050 \mathrm{~F}$, compared with a calculated 15 per cent minimum loss per hr based on diffusion data.

Specimens have also been prepared to study the effect of binders on boron loss. As indicated in Table $\mathrm{T}-3$, there does not appear to be any definite relationship between boron content and the type or amount of binder used in the se fabricated plates. 
TABLE T - 2. END EFFECTS CAUSED BY VARIATIONS IN ROLLING

\begin{tabular}{|c|c|c|c|c|c|c|c|c|c|}
\hline \multirow[b]{4}{*}{ Plate } & \multirow{4}{*}{$\begin{array}{c}\text { Rolling } \\
\text { Temperature, } \\
\text { F } \\
\end{array}$} & \multirow{4}{*}{$\begin{array}{l}\text { Rolling } \\
\text { Direction }\end{array}$} & & & & \multicolumn{4}{|c|}{ Core End Effects } \\
\hline & & & & & & \multicolumn{2}{|c|}{ Suppressor End } & \multicolumn{2}{|c|}{ Stem End } \\
\hline & & & \multicolumn{3}{|c|}{ Rolling Reduction, per cent(a) } & \multirow{2}{*}{$\begin{array}{c}\text { Feathering, } \\
\text { in. }\end{array}$} & \multirow{2}{*}{$\begin{array}{c}\text { Tailing, } \\
\text { in. }\end{array}$} & \multirow{2}{*}{$\begin{array}{c}\text { Feathering, } \\
\text { in. }\end{array}$} & \multirow{2}{*}{$\begin{array}{c}\text { Tailing, } \\
\text { in. }\end{array}$} \\
\hline & & & First Pass & Second Pass & Balance & & & & \\
\hline 81 & 2000 & Stem first & 40 & 20 & 20 & 0.03 & 0.22 & 0.13 & -- \\
\hline \multirow[t]{2}{*}{82} & 2200 & Stem first & 30 & 30 & -- & -- & -- & -- & $\cdots$ \\
\hline & 2000 & -- & -- & -- & 20 & 0.02 & 0.1 & 0.04 & -- \\
\hline \multirow[t]{2}{*}{83} & 2200 & Stem first & 40 & $-\infty$ & -- & -- & -- & $-\infty$ & -- \\
\hline & 2000 & -- & -- & 20 & 20 & -- & 0.1 & 0.07 & -- \\
\hline 84 & 2200 & Stem first & 40 & 20 & 20 & -- & 0.1 & 0.07 & -- \\
\hline 85 & 2200 & Stem first & 30 & 30 & 20 & -- & 0.15 & 0.05 & -- \\
\hline 86 & 2200 & Suppressor first & 40 & 20 & 20 & 0.06 & -- & -- & 0.1 \\
\hline 87 & 2200 & Suppressor first & 30 & 30 & 20 & 0.04 & -- & - & 0.1 \\
\hline $88^{(b)}$ & 2200 & Suppressor first & 40 & 20 & 20 & 0.02 & -- & - & 0.2 \\
\hline $89^{(b)}$ & 2200 & Suppressor first & 30 & 30 & 20 & 0.16 & $-\infty$ & $-\infty$ & 0.17 \\
\hline
\end{tabular}

(a) 0.25 -in. cores given a total reduction of about $8.3: 1$.

(b) All packs flipped and reversed between hot-rolling passes, except Plates 88 and 89 . These were rolled suppressor first each time. A cold reduction of 18 per cent followed hot rolling. 
$\mathrm{T}-5$

Metallography has not been completed, and an accurate estimation of boron loss cannot be made until core thickness is measured. Flowever, over the range of values expected, it appears that there has been very little boron lost.

TABLE T-3. EFFECT OF BINDER ADDITIONS ON BORON CONTENT OF FABRICATED PLATES

\begin{tabular}{lc}
\hline \multicolumn{1}{c}{ Binder Added $^{(a)}$} & $\begin{array}{c}\text { Boron Content } \\
\text { (b) }\end{array}$ \\
\hline None & 0.190 \\
<1/2 w/o camphor-methanol & 0.199 \\
1/2 w/o camphor-methanol & 0.201 \\
1 w/o camphor -methanol & 0.198 \\
1/2 w/o Ceremul "C" & 0.204 \\
1/2 w/o Carbowax 6000 & 0.192 \\
\hline
\end{tabular}

(a) Amount indicated is weight per cent of core.

(b) Includes approximately 5-mil-thick cladding on two surfaces.

Encapsulation Studies

J. F. Lagedrost, W. E. Murr, and J. H. Stang

Reference and alternate SM-2 fuel-test specimens are being irradiated in the MTR and the ETR. The target specimen-surface temperatures are in the 600 to $650 \mathrm{~F}$ range. Target burnups range from about 40 uranium a/o for the ETR capsule to about 70 uranium a/o for the MTR capsules.

The three noninstrumented capsules (BMI-32-1, BMI-32-2, and BMI-32-3) being irradiated in the MTR core are scheduled to be discharged on March 28, 1960. The first instrumented capsule, BMI-32-4, is also scheduled to be discharged from its ETR beryllium-reflector position about March 28, 1960. The last operating thermocouple in this capsule failed when the reactor returned to power following a scram on February 7 . Prior to the scram the couple had shown temperatures in the 400 to $405 \mathrm{~F}$ range which indicated that specimen-surface temperatures were in the neighborhood of $650 \mathrm{~F}$. Actually, these surface temperatures are about the same as those at the start of the irradiation. This consistency of temperature has rot been expected in view of the estimated rate of depletion of fuel. At the presently estimated burnup of approximately 30 uranium a/o, a general temperature-level reduction of at least $50 \mathrm{~F}$ would be anticipated. It may be that the thermocouple did not read correctly, that the neutron flux may have increased in proportion to the fuel burnout, or that the boron added as a burnable poison is behaving in an ideal fashion to smooth out burnup.

The four capsules will be returned to the Battelle hot cell during the first 2 weeks of April for postirradiation examination. It is expected that the capsules will be opened and examination of the specimens will be essentially complete by mid-June, 1960. 


$$
T-6
$$

Three of the six remaining instrumented capsules have been assembled and sent to the ETR. Of these, BMI-32-5 is scheduled for insertion during Cycle 28 shutdown (late March or early April), and BMI-32-6 and BMI-32-8 will probably be inserted during the following shutdown. Capsule BMI-32-9 will be completed early in March, and BMI-32-7 and BMI-32-10 probably by mid-April. 
$\mathrm{U}-1$

GAS-COOLED REACTOR PROGRAM (AGN)

D. L. Keller

Studies for Aerojet-General Nucleonics directed toward the development of compact gas-cooled reactors are reported in this section. The activities on the various task:; are reported undex "Materials Development Program" and "In-Pile-Loop Proqram".

\section{MATERIALS DEVELOPMENT PROGRAM}

D. L. Keller

The fabrication of $\mathrm{UO}_{2}-\mathrm{BeO}$ fuel pellets for various reactor experiments is continuing. Chemical analyses, density measurements, and recovery percentages are reported on the first sroup of approximately 3000 pellets.

Further progress of in-pile capsule irradiations is reported; however, no hot-cell evaluation was performed during February.

Construction has been completed on the ML-1-IB critical assembly, and final adjustroents are being made in preparation for receiving the fuel from AGN around the first of A]ril.

One-kilogram ingots of modified Hastelloy $\mathrm{X}$ alloys were induction melted, forged at $2 \overline{2}, 00 \mathrm{~F}$, and rolled at $2200 \mathrm{~F}$ to $0.060-\mathrm{in}$. sheet. The effect of yttrium and niobium addilions as well as the effect of varying the base-alloy composition will be evaluated from the standpoint of mechanical properties and corrosion resistance. The latter work will be performed at AGN.

Fabrication of $\mathrm{BeO}-\mathrm{UO}_{2}$ Fuel Pellets

H. D. Sheets and A. K. Smalley

The objective of this program is to prepare BeO ceramics containing fuel-enriched $\mathrm{UO}_{2}$ for loop exposure.

Fabrication of 2966 acceptable hollow pellets $0.200 \pm 0.030 \mathrm{in}$. high with an OD of $0.1745 \pm 0.0015 \mathrm{in.}$ and an ID of $0.055 \mathrm{in.}$ was completed during February; 82.6 per cent of the pellets sintered were acceptable. Of the pellets sintered 10.4 per cent were outside diametral tolerance, 4.8 per cent were chipped, and 2.2 per cent were rejected because of internal flaws detected by radiography. Bulk-density measurements on specimen; chosen from each lot indicated that the bulk density of the sintered pellets ranged from 4.90 to $5.09 \mathrm{~g}$ per $\mathrm{cm}^{3}$ (about 94 to 98 per cent of theoretical). Chemical analyses 
for $\mathrm{UO}_{2}$ content on 15 pellets ranged from 58.0 to $60.1 \mathrm{w} / \mathrm{o}$, with an average of 59.1 w/o. The $\mathrm{UO}_{2}$ in these same pellets had an oxygen-to-uranium ratio ranging from 2.00 to 2.05 , as determined by a weight-gain technique. Metallographic examination revealed that these pellets were similar in microstructure to the previously prepared capsule specimens.

Fabrication of an additional 4000 pellets of the same dimensions, but with slightly higher fuel loading, for additional experiments will be started as soon as $\mathrm{UO}_{2}$ fuel can be procured.

\section{Encapsulation Studies}

J. H. Stang, J. F. Lagedrost, and D. W. Nicholson

Irradiation of Specimens Containing MCW Spherical UO2 Dispersed in Stainless Steel

The irradiation stability of $\mathrm{MCW}$ spherical and ORNL hydrothermal $\mathrm{UO}_{2}(30 \mathrm{w} / \mathrm{o}$ highly enriched) dispersed in stainless steel is under investigation. Two plate-type specimens of each type are being irradiated in Capsules BMI-33-1 and BMI-33-2 now in the MTR.

The specimens in BMI-33-1 are undergoing a six-reactor-cycle exposure at center-line temperatures in the 1075 to $1275 \mathrm{~F}$ range (calculated from the rmocouple data). Estimated fission burnup levels of 12 to 15 a/o will be achieved at the March 28, 1960, scheduled discharge date. Capsule BMI-33-2, in which specimen temperatures during its first reactor cycle were approximately the same as those in BMI-33-1, was moved to a higher flux position for three additional cycles. Specimen center-line temperatures after the move were in the 1400 to $1650 \mathrm{~F}$ range (calculated). This capsule is also scheduled for discharge on March 28, 1960, by which time its specimens should reach burnup levels in the 9 to 11 a/ o range.

$\mathrm{UO}_{2}-\mathrm{BeO}$ Irradiation Studies (AGN)

This program involves studies of irradiation effects on Hastelloy X-clad dispersions of highly enriched $\mathrm{UO}_{2}$ in $\mathrm{BeO}$. Six small cylindrical specimens, contained in Capsule AGN-BRR-II, are being irradiated at a nominal $1725 \mathrm{~F}$ surface temperature in the BRR core.

The capsule is scheduled to be discharged from the reactor about March 7, 1960, after its fourth 2-week cycle. The two electric heaters and five of the six thermocouples originally present continue to operate satisfactorily. During the second and third cycles, the center two specimens were maintained at design temperature (nominally, $1725 \mathrm{~F}$ at the specimen surfaces) 84 per cent $(450 \mathrm{hr})$ of the reactor operation time; the corresponding minimum specimen-surface temperature was about $1600 \mathrm{~F}$. These temperatures are estimated from data provided by intracapsule thermocouples 
$\mathrm{U}-3$

located very close to the specimens. During the remaining 16 per cent of the time, lowe: temperatures were observed because ( 1 ) the reactor was operated at reduced power, or (2) the auxiliary-heat-input circuit was opened by a momentary temperature excu:sion above $1750 \mathrm{~F}$, the maximum allowable specimen-surface temperature.

Operation during the fourth cycle has been similar to that observed during the second and third cycles. It is estimated that the total burnup of the specimens will reacl $2-1 / 2$ to 3 a/o at discharge.

\section{Effects of Ir:radiation}

J. H. Saling, W. E. Murr, J. E. Gates, and R. F. Dickerson

No hot-cell evaluation was performed during February.

GCRE Critical-Asse:mbly Experiments

J. W. Ray, R. G. Matthews, W. S. Hogan,

D. A. Dingee, and J. W. Chastain

Construction has been completed on the ML-1-lB critical assembly. During the past : month the supports for the scissors-acting control blades were fabricated and as sembled. In addition, final checkouts and adjustments were made on liquid-level indicators, neutron-source drive, and control-rod drives and position-limit switches.

Next month the fuel-element containers and fuel-storage area will be cleaned up in prepiration for receipt of fuel around the first of April. Final adjustments will be made on reactor instrumentation and controls, and the interlock system will be checked.

\section{Alloy Modification of Hastelloy X}

J. A. DeMastry, A. A. Bauer, and R. F. Dickerson

Hastelloy $\mathrm{X}$ is the material that has been chosen for application as the fuel cladding in the reactor. Exposure of this material to a nitrogen-1/2 volume per cent oxygen atmosphere at $1750 \mathrm{~F}$ has resulted in a loss of ductility (from 40 per cent total elongation to 12 per cent total elongation) after $5000 \mathrm{hr}$. Further exposure could lead to more serious losses in ductility and possible cladding failure. It is believed that either grain growlh or carbide precipitation may be responsible for the los of ductility observed. The loss in ductility due to grain growth may be remedied by adding a grain refiner such as yttrium. The embrittling effect of carbides in the grain boundaries can be counteracted by niobium or yttrium additions which may produce a more favorable phase distribution or act as a ductile matrix for carbide precipitation. 
The effect of alloying additions which may improve the ductility of Hastelloy $\mathrm{X}$ after exposure to the nitrogen-1/2 volume per cent oxygen atmosphere and which also may improve the oxidation resistance of the material is being studied. Niobium and yttrium are being added for this purpose. The effect of variations in the base-alloy composition is also being studied. Chromium and nickel contents are being increased at the expense of the iron present in the alloy, and the carbon content is being varied. The base composition is nickel-2l w/o chromium $20 \mathrm{w} / 0$ iron $-10 \mathrm{w} / 0$ molybdenum $-0.7 \mathrm{w} / 0$ tungsten $-1.0 \mathrm{w} / 0$ mangane $\mathrm{se}-1.0 \mathrm{w} / 0$ silicon $-0.1 \mathrm{w} / 0$ carbon.

One-kilogram ingots were induction melted in alumina crucibles and poured at $2900 \mathrm{~F}$ into $\mathrm{Zirconite}$ molds. These were forged at $2200 \mathrm{~F}$ to slabs and then rolled at $2200 \mathrm{~F}$ to $0.060-\mathrm{in}$. sheet. All of the alloys except one, containing a $1 \mathrm{w} / \mathrm{o} \mathrm{yttrium} \mathrm{ad-}$ dition and $25 \mathrm{w} / \mathrm{o}$ chromium instead of $21 \mathrm{w} / \mathrm{o}$, were successfully reduced 95 per cent. This alloy fractured during forging; a duplicate is being prepared.

A portion of the fabricated sheet has been sent to Aerojet General for corrosion testing. Tensile specimens for testing at 75, 1000, 1750, and $1850 \mathrm{~F}$ in air are being prepared from the remaining sheet.

Samples for metallographic examination and chemical analyses have been obtained from the as-cast ingots and are being processed.

\section{IN-PILE-LOOP PROGRAM}

G. A. Francis

During the period covered by this report, activity on the loop program was continued. At the Battelle Research Reactor, preparation for operation of the recirculating in-pile gas loop was continued, and a change was made in experiment plans. The Engineering Test Reactor loop fuel-specimen irradiation was delayed by mechanical problems associated with blower operation.

\section{BRR Loop Program}

W. G. Rieder, S. J. Basham, and W. H. Goldthwaite

Preparation for operation of the loop was continued during February. The major activities were associated with calibration of the new gas-monitoring system and the performance of a flux run.

The continuous loop gas-monitoring-system calibration will be based on data obtained by introducing fission gases into the sensing chamber. The actual calibration runs have been completed, and the data are being reduced. The calibration will be completed and the sensitivity of the device will be established during initial irradiation of a 


$$
\text { U-5 and U-6 }
$$

test specimen. It is planned that the instrument will be used as a reactor scramactuating device during future tests.

A fuel subassembly designated 1B-2T was received from Aerojet General Nucleonic; and was used in a flux run. The data will be reduced and reported in the next regular progress report.

A change in the AGN's irradiation plans has set the next irradiation to start during March. The specimen will be a pin-type unit instrumented for thermal cycling. The test will run for approximately $1000 \mathrm{hr}$ and will be followed by a similar specimen instrumented for engineering information.

\section{ETR Loop Program}

E. O. Fromm, J. V. Baum, A. M. Rockwood, and G. A. Francis

Problems encountered both at the reactor site and during blower tests at Battelle have resulted in a hange of irradiation plans. Shortly before the scheduled insertion of the 1-3P fuel subassembly, a belt failure occurred on the operating blower at the reactor site. At Battelle a belt failure occurred after $680 \mathrm{hr}$ of operation.

To summarize, since the blower modification last October, there have been three belt :ailures. These occurred after 554,503 , and $680 \mathrm{hr}$ of operation at design conditions. The reactor cycle is approximately $500 \mathrm{hr}$, and the loop system has three blowirs in position at all times with one operating.

Since the belt performance was not acceptable, the element was not inserted during February. It has been decided to make minor drive modifications based on experience and the belt manufacturer's recommendations. It is planned that the $1-3 \mathrm{P}$ will be insert $\epsilon$ d at the end of the next ETR operating cycle if the blowe $x$ modifications are completed and the test of a modified blower at Battelle has been under way 550 to $600 \mathrm{hr}$. Present project activity is being directed toward this modification and operation.

Other activity during February included the installation of a new loop heater control at the site. The control was furnished by the original supplier and appears to function :atisfactorily. At Battelle the blower test was continued. The unit on test which has rot been modifed has run $1300 \mathrm{hr}$ without regreasing. An inspection after $610 \mathrm{hr}$ of belt uperation revealed no indication of incipient failure. This test indicates that a belt drive system would be satisfactory for use during specimen irradiations. The test will be ccintinued until the modified system can be prepared for operation. 
-

$=$

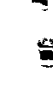

.

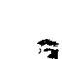

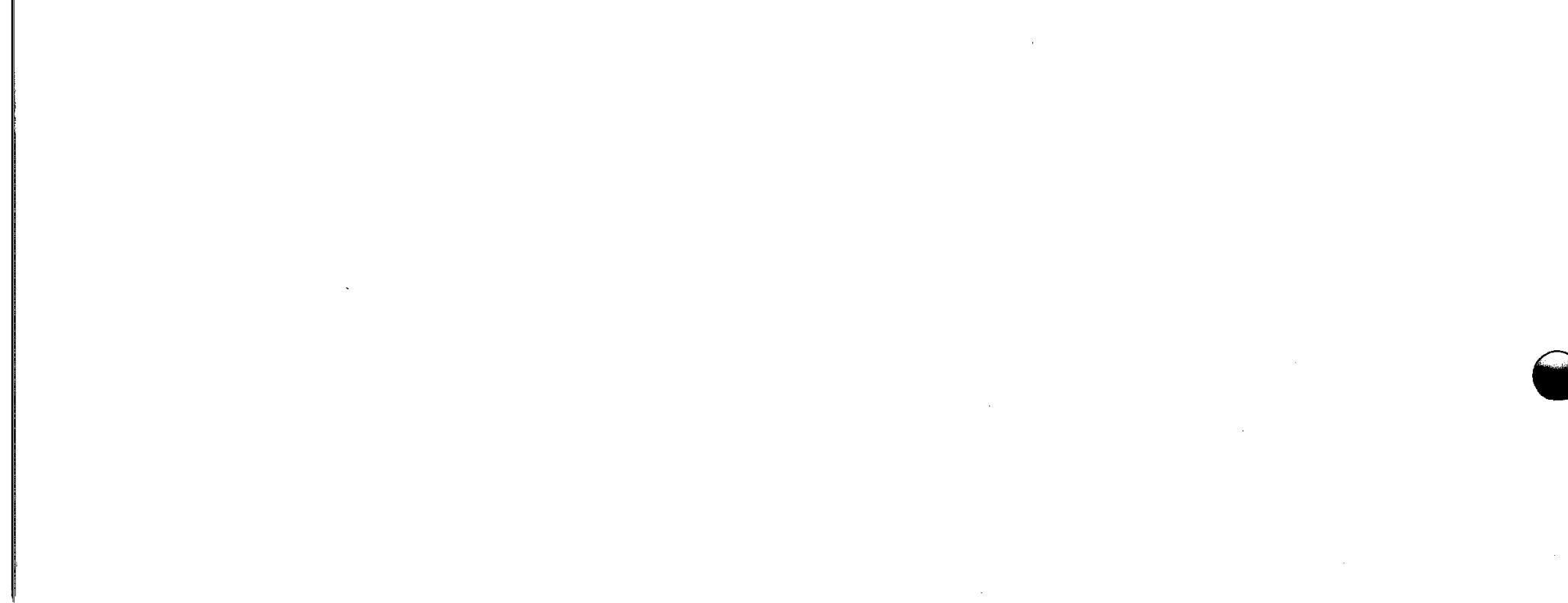




$$
\mathrm{V}-1 \text { and } \mathrm{V}-2
$$

\title{
A STUDY OF THE CORROSION RESISTANCE OF THORIUM AND URANIUM UNDER ATMOSPFEERIC CONDITIONS (UCRL)
}

E. F. Stephan, P. D. Mliller, and F. W. Fink

\begin{abstract}
Preliminary work has started to determine the corrosion resistance of thorium, uranium, and certain uranium alloys during storage under atmospheric conditions.

Equipment is being assembled to evaluatte the se materials under a variety of laborato:y conditions simulating several stages of storage. Preliminary studies will be made with bare and coated coupons which will be available late in March.
\end{abstract}

RW D:CRT:all 